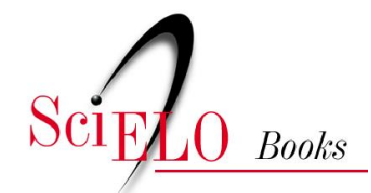

\title{
Infância, imagens e vertigens
}

\author{
Bianca Santos Chisté
}

CHISTÉ, BS. Infância, imagens e vertigens [online]. São Paulo: Editora UNESP; São Paulo: Cultura Acadêmica, 2015, 153 p. ISBN 978-85-7983-708-1. Available from: doi: 10.7476/9788579837081. Also available in ePUB from: http://books.scielo.org/id/zdx9x/epub/chiste-9788579837081.epub.

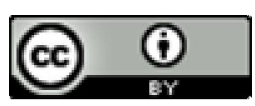

All the contents of this work, except where otherwise noted, is licensed under a Creative Commons Attribution 4.0 International license.

Todo o conteúdo deste trabalho, exceto quando houver ressalva, é publicado sob a licença Creative Commons Atribição 4.0.

Todo el contenido de esta obra, excepto donde se indique lo contrario, está bajo licencia de la licencia $\underline{\text { Creative Commons }}$ $\underline{\text { Reconocimento } 4.0 .}$. 


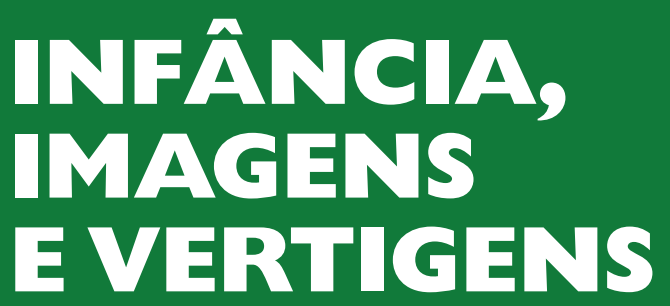

BIANCA SANTOS CHISTÉ 


\section{INFÂNCIA, IMAGENS E VERTIGENS}


Conselho Editorial Acadêmico

Roger Miarka

Rosa Monteiro Paulo

Rosana Giaretta Sguerra Miskulin 


\section{Bianca Santos Chisté}

\section{INFÂNCIA, IMAGENS E VERTIGENS}


(C) 2015 Editora Unesp

\section{Cultura Acadêmica}

Praça da Sé, 108

01001-900 - São Paulo - SP

Tel.: (0xx11) 3242-7171

Fax: (0xx11) 3242-7172

www.editoraunesp.com.br

www.livrariaunesp.com.br

feu@editora.unesp.br

CIP - BRASIL. CATALOGAÇÃO NA PUBLICAÇÃO

SINDICATO NACIONAL DOS EDITORES DE LIVROS, RJ

\section{C47i}

Chisté, Bianca Santos

Infância, imagens e vertigens / Bianca Santos Chisté. São Paulo:

Cultura Acadêmica, 2015.

Recurso digital

Formato: ePub

Requisitos do sistema: Adobe Digital Editions

Modo de acesso: World Wide Web

ISBN 978-85-7983-708-1 (recurso eletrônico)

1. Psicologia educacional. 2 Educação. 3. Livros eletrônicos. I. Título.

$15-28929$

CDD: 370.15

CDU: 37.015 .3

Este livro é publicado pelo Programa de Publicações Digitais da Pró-Reitoria de Pós-Graduação da Universidade Estadual Paulista "Júlio de Mesquita Filho" (UNESP)

Editora afiliada:

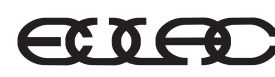

Asociación de Editoriales Universitarias de América Latina y el Caribe

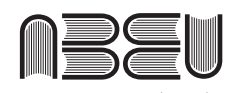

Associação Brasileira de Editoras Universitárias 
Enquanto você

Se esforça pra ser

Um sujeito normal

E fazer tudo igual

Eu do meu lado

Aprendendo a ser louco

Um maluco total

$\mathrm{Na}$ loucura real

Controlando

A minha maluquês

Misturada

Com minha lucidez

Vou ficar

Ficar com certeza

Maluco beleza

Eu vou ficar

Ficar com certeza

Maluco beleza

E esse caminho

Que eu mesmo escolhi

É tão fácil seguir

Por não ter onde ir 
Controlando

A minha maluquês

Misturada

Com minha lucidez

Eu!

Controlando

A minha maluquês

Misturada

Com minha lucidez

Vou ficar

Ficar com certeza

Maluco beleza

(Raul Seixas, Maluco beleza) 
Saber que as crianças alcançam o impensável.

Ver muitas vezes professoras contagiadas pela alegria da infância.

Ver na educação infantil um espaço de reuniões, de assembleias, de concílios infantis.

Por toda parte, sentir o segredo das crianças.

Gostar de viver na clandestinidade, na incerteza, na insegurança provocada pela infância, pelas crianças, pelas imagens produzidas por elas.

Gostar de estar ali caminhando com elas. Gostar dessa emoção tão cheia de riquezas intimas.

Descobrir uma amizade sensível em César Leite. Dar um suspiro bom de alivio. Olhar com ternura nossas inventividades.

Lembrar-se das conversas com amigos próximos, com amigos distantes e se alegrar nos encontros com Sônia Clareto, Silvio Gallo, Maria Rosa, Antônio Carreta, Leda Cabral, Luana Oliveira. Lembrar-se de leituras passadas, das leituras futuras, das leituras presentes com certa inocência e rir sozinha.

Lembrar-se da família. Recordar um pouco.

Ter vontade de escrever para cada um: irmãos, pai, sobrinhos, filhas, marido, cunhados, mãe. 
Ter vontade de lhes contar a vida até o momento. Pensar em encontrá-los de novo.

Pensar em reuni-los em torno de uma mesa. Sempre uma mesa!

Uma mesa qualquer em um lugar que a gente ainda não escolheu.

Conversar com todos eles. Rir, cantar, recordar os dias idos.

Imaginar o semblante da mamãe Maria se nos reencontrássemos.

Imaginar que ela já vem. Abrir os braços.

Como é bom ter tido infância e perceber que isso não está no passado.

Como é bom chegar a este ponto de olhar em torno $E$ se sentir bem porque descobriu outras vidas.

Como é bom achar o mundo estranho por isso, muito estranho mesmo.

$E$ depois sorrir levemente para ele com os seus mistérios ...

Saber... Ver... Gostar... Descobrir... Lembrar... Ter Vontade... Pensar... Imaginar... Como é bom... Como é bom... Agradecer! 


\section{SUMÁRIO}

Pré-fância de um texto ensaio 11

Compondo e pondo sem ponto 15

1 Penteando e desarrumando a pesquisa 23

2 Vestígios de infância 53

3 Rastros de proposições crianceiras 85

4 Delírios irracionais da imaginação 109

Encontros com... 141

Um pós-escrito de um ensaio em composição 145 


\section{Pré-FÂNCIA de UM teXto ensalo}

Depois que iniciei minha ascensão para a infância, Foi que vi como o adulto é sensato!

[...]

Como não ascender ainda mais até na ausência da voz?

[...]

Por que não ascender de volta para o tartamudo.

(Manoel de Barros, Ascensão)

Começo esta breve apresentação do texto de Bianca Santos Chisté com um fragmento do poema de Manoel de Barros, talvez e possivelmente pelas inúmeras aberturas que ele nos oferece poderíamos ficar apenas nele! Ascender à infância! Eis a afirmação que por si só já seria um convite a leitura de um texto que desloca olhares, crias vias e desvias nos percursos, caminhos, um texto que nos diz que conceitos, ideias não são meramente ideológicos, mas, como diz Deleuze sobre Godard (Conversações, 2010 p.55), uma ideia é uma prática, ou ainda, continuando com Deleuze sobre Godard

Godard tem uma bela fórmula: não uma imagem justa, justo uma imagem. Os filósofos também deveriam dizê-lo, 
e conseguir fazer: não ideias justas, mas "justo ideias". Porque ideias justas são sempre ideias conformes a significação dominantes ou a palavras de ordem estabelecidas, são sempre ideias que verificam algo, mesmo se esse algo está por vir, mesmo se é o porvir da revolução. Enquanto que "justo ideias" é próprio do devir-presente, é a gagueira nas ideias; isso só pode se exprimir na forma de questões, que de preferência fazem calar as respostas. Ou mostrar algo simples que quebra todas as demonstrações.

O convite de Bianca para fazer um convite ao leitor passa necessariamente aí: criar um desenho que possa apresentar um texto que se coloca como um devir- presente, povoado de ideias gaguejantes, perguntas que soam e se fazem mais presentes que respostas, um texto que circula e faz circular afetos, pensamentos, infâncias.

Um prefácio deve, por protocolo, estar no começo de um texto, deve apresentar um texto; um prefácio, em certo sentido, inaugura um texto! Porém, como inaugurar algo que é a própria inauguração, o próprio começo? O que vem antes do começo? O que pode estar antes daquilo que como começo inaugura?

O texto de Bianca Chisté é povoado de inícios, de começos e mesmo naquilo que podemos pensar como conclusivo nele apenas inaugura!

Talvez por isso o texto incomoda, vai incomodando (talvez como a infância de Lyotard!). Talvez por isso, na primeira leitura, seduz e depois nos permite ver lacunas, brechas, espaços! Porque o texto não se apresenta como algo que sossega, que acalma ou como algo que procura seduzir! O texto, diferentemente do que pensamos ou muitas vezes proclamamos por aí, não nos diz que a infância é um território seguro e puro de uma saudade, mas a infância "é aquela que se aborda através de seu meio, que se abre aos diversos dados dos sentidos e das coisas. À linguagem das coisas" (Schérer, Infantis, p.207). 
O presente texto nos apresenta e nos faz este convite. Por isso, caro leitor, se você espera encontrar soluções, ideias prontas, discurso adulto, adultizado, talvez a leitura não seja a mais adequada; aqui certamente encontrará uma escrita que se apresenta como imagem, como uma imagem da infância. Vale ressaltar neste aspecto que o texto é também uma composição, uma composição (talvez como as de nossa infância) entre imagens e escritas, é um texto escrito por imagens, é um texto-imagens de nossas escritas. O texto de Bianca é produto das próprias ideias atravessando palavras e imagens e sendo atravessada por elas.

Sendo assim, um texto de educação, de educação infantil, de educação matemática na educação infantil poderia "inaugurar os formatos desformando-os incessantemente poderia acontecer em uma educação vagamundo, em uma educação dançarina? Uma educação transeunte, deslizantes de movimentos rápidos, leves, uma educação que se experimenta e se deixa experimentar, que está sempre criando, inventando, se modificando. Uma educação que invoca aumentar a potência de agir, fazer a vida vibrar e se inventar, acionar a diferença, a invenção, movimentar encontros e composições..." (Chisté, Devir criança da matemática: experiências educativas infantis imagéticas).

Fica aqui o convite, fica aqui as reticências....

Boa leitura.

César Donizetti Pereira Leite Departamento de Educação da Unesp, campus de Rio Claro 


\section{COMPONDO E PONDO SEM PONTO}

Olha... Tá filmando eu mesmo!!!

(Pré II, 2012, 15 9) ${ }^{1}$

Sempre compreendo o que faço depois que já fiz. O que sempre faço, nem seja uma aplicação de estudo.

É sempre uma descoberta.

Não é nada procurado. É achado mesmo.

(Barros, 2010, p.85)

No início não sabia exatamente o que escrever, ou mesmo como fazê-lo, tinha apenas algumas intuições e uma profunda inquietude. Sabia que o texto, não seria nem mesmo parecido, com alguma das coisas que escrevo. Assim, este texto se apresenta assim... como

1 As imagens e as falas das crianças foram retiradas das filmagens produzidas por elas durante o período que estive na escola. Optei por referenciá-las de acordo com a maneira que os documentos imagéticos foram arquivados. Dessa maneira, o número ordinal refere-se à ordem ao dia (primeiro dia, segundo dia, e assim sucessivamente), o número cardinal em seguida refere-se ao número da filmagem no dia. 
uma composição, um ajuntamento de pensamentos, ideias, desejos, afetos, anseios. Parece que compor tem essa intencionalidade: a reunião de elementos isolados que, quando unidos, resultam em um todo destacado por pedaços. Mas, compor não é algo tão simples, como sua definição nos leva a entender. Compor uma composição exige do compositor: criatividade, inventividade, alguns delírios, desvarios, insônias, renúncias e deslocamentos. Parece que uma composição vai sendo escrita a partir das coisas que afetam, incomodam, tocam na pele, tocam no corpo. A composição é movida por afetações e sensações, em um movimento de experimentação; é dessa forma que a partitura vai se constituindo.

Uma composição me leva a pensar em montagem, não de peças previamente moldadas, que se engrena, se engatam, como se já estivesse delimitadas para "funcionar", para dar certo. Mas, montagem de fragmentos, de cacos, talvez de sobras, de restos, de resíduos, de esboços, que ao montado, ao composto, não se sabe exatamente o que pode resultar, ou mesmo a potência dessa composição. Seria como uma bricolagem, uma brincadeira de colar e montar, de aproximar autores, ideias, pensamentos, experiências, imagens, infância, criança, matemática e pensar com essas aproximações, com esses encontros em um movimento de criação e experimentação com a escrita.

Uma composição abre possibilidades de ser montada, bricolada; não existe uma única maneira, existem maneiras inumeráveis, por isso, ela pode ser tentativas, provas, ensaios, experiências de montagem, de bricolagem. É dessa forma que essa escrita também se apresenta: um ensaio. Um texto, uma composição que se ensaia trata de ensaiar um pensamento, de "experimentar seus limites e de inventar suas possibilidades” (Larrosa, 2010, p.11). É como se fosse impulsionada por um segundo, a aventurar-se em uma viagem, uma viagem aberta, sem 
planejamento, sem rota traçada, sem destino previsto e seguro, ou como diz, Larrosa (2010, p.52-3) "Uma aventura, é justamente, uma viagem no não planejado e não traçado antecipadamente, uma viagem aberta em que pode acontecer qualquer coisa, e na qual não se sabe onde se vai chegar, nem mesmo se vai se chegar a algum lugar". Assim, mergulhada na desproporção da experiência, ela pode ser a todo o momento interrompida, ou seja, o ensaio, a composição só pode ser curso interrompido. Foi assim que essa composição, esse ensaio se iniciou.

Apresentar um ensaio então seria como apresentar um texto infantil, infante, um texto-infância, um texto menor, um texto ainda por vir, um texto porvir, um texto ainda não pronto, um texto que ensaia, para que dele se experimente, mas também que ele se experimente como texto. (Leite; Leite, 2014, p.1-2)

Dessa maneira, a composição, o pensamento que se ensaia aqui, foi pensada no momento mesmo em que este texto foi, vai, se fazendo, se constituindo, se criando; como um proceder tateante, mais experimental, mais degustativo, mais sensitivo. A intenção aqui é experimentar com pensamento, experimentar uma escrita, por que não dizer, uma escrita infantil. Uma escrita que é um convite ao pensamento, um convite à experimentação, um convite a afastar a uma pretensão de saber, a distanciar dos efeitos dos sentidos dados. Assim, a preocupação foi compor um texto que colocasse o pensamento em movimento, que me (nos) colocasse para pensar com a infância, sem preocupar-se em conceituar, definir, descrever, explicar, representar e interpretar. Ele não contribui para constatar uma pressuposta verdade, mas, sim, parece-me, transformar a relação que tenho - quem sabe, temos - com a infância, com as crianças, com o mundo, comigo mesma.

$\mathrm{O}$ exercício do pensamento aqui encontrou algo que o obrigou a pensar, foi um encontro fortuito, produto do 
acaso, produto do acontecimento. O encontro com a infância, com as crianças, com as imagens, com as falas, com a sonoridade e o sabor do encontro, sensibilizou, desencadeou uma força irrefreável que me parece, problematizou o não problematizado, pensou, quem sabe, o não pensado.

Parece que tenho muitas coisas para falar, para pensar, para compor, mas só consigo trazer para essa composição uma pequena parte delas, como num "discurso tartamudeante e tossiquento” (Calvino, 1994, p.37). Decido então, a experimentar com imagens infantis, com falas infantis, com experiências infantis, com imagens epígrafes, com falas epígrafes, com poemas, com poemas-criança. Estas experiências estão em um universo que chamarei, ajudada por Leite e Leite (2014) de imagens e cenas lúdicas de experiências infantis. O cenário é o de uma pesquisa de produção de imagens por crianças da educação infantil, crianças da pré-escola, e as cenas são de imagens daquilo que nos parece espaços lúdicos de exploração do mundo, dos seres, das coisas, daquilo que se produz pelos e com os equipamentos.

Essa composição, esse ensaio bricoleur, é um texto criado por meio de bricolagem, um texto composto por diferentes trechos de outros textos colados, através de um processo de bricolagem. BrIcolagem, bRIncadeira de criança: cortar, colar, compor. Cortar poemas, compor pensamentos, cortar palavras, compor palavras, cenas montadas e recortadas, flash de imagens, imagens confusas, embaçadas, rodopiantes, vertiginosas, movimentos lentos, rápidos. É isso que tento fazer, compor com peças soltas, incompletas, que ora se encaixam, ora não, vou então retirando algumas, colocando outras, em um movimento mesmo de experimentação, de experimentar a escrita, a composição e decomposição do ensaio, testando possibilidades. As peças soltas dispostas não foram pensadas para estar juntas, mas na brincadeira foi se criando 
um comum. Como em toda brincadeira, não se sabe muito bem como começa, nem como termina, sabe-se talvez que o desejo pelo brincar, pelo compor, pelo decompor, envolve um comum partilhado. Na expressão de Brasil (2008, p.15):

O bricoleur é filho de Kairós, ele que se move pelas situações, atento às ocasiões, não se submete a um projeto rígido e compõe conjuntos abertos. Como reapropriação astuta e negligente daquilo que nos é constantemente expropriado, a bricolagem nos religa a uma infância sempre presente.

Dessa maneira, como não há um roteiro prévio para se brincar, assim, o que se compõem aqui não deve seguir um percurso estabelecido a priori, nem mesmo uma expectativa fechada. Trata-se mais de um deslizar entre o texto, as palavras, escorregar entre as letras, os poemas, passear entre as imagens, de irromper no meio deles e fazer surgir algo que force o pensamento a pensar. O que pode o leitor nessa composição? Pode a leitura de olhos se prender e se perder nas imagens, passar ou pular as páginas, voltar, passear pelos rastros deixados pelas letras, escorregar entre as imagens, se deter em algum lugar, rachar as palavras, não ler todo o texto, ler um trecho aqui outro ali, se calar; e como a Alice (Carroll, 2002) se aventurar em um buraco, por força da curiosidade e da ousadia, para operar uma fissura no tempo que segue encadeado em um texto se quer em movimento.

Palavras e fazer, conteúdo, forma, composição, fala de criança, fala-criança. Quem é o autor? Quem são os autores das vozes transcritas das filmagens? O que acontece se retirarmos a identidade das vozes? E se dessubjetivarmos a autoria? Essas vozes tornam-se poemas-criança, que dispersa individualidades e se talha e coagula como leite? Há um todo e uma unidade nessas vozes, que não as totaliza e nem as unifica, mas sim, se junta a essa 
multiplicidade vocal como uma nova "parte composta à parte”. Aqui a voz das crianças é uma contaminação, a voz é de uma, de mais uma, mais uma, mais uma...Ou como nos diz Deleuze e Guattari (2010, p.63) “[...] pedaços de quebra-cabeça que não são do mesmo, mas de diferentes quebra-cabeças, violentamente inseridos uns nos outros, sempre locais e nunca específicos, e com suas bordas discordantes, sempre forçadas, profanadas, imbricadas umas nas outras, e sempre com restos". Multiplicidade de vozes dispersa e anárquica entrelaçadas, atravessadas pela própria ausência de ligação, de estrutura, de memória e de organismo.

Decido então, a dividir essa composição em quatro momentos, momentos estes que componho restos, sobras, esboços, resíduos do que a infância, as crianças, as imagens, outros pensadores foram deixando em mim, me afetando, me tocando, mobilizando, violentando o pensamento. Desse modo, no primeiro momento, "Penteando e desarrumando a pesquisa", trago um pouco da relação com a pesquisa, na qual me faz pensar em intimidade, experiência e infância, nos riscos que se corre ao se lançar em uma pesquisa como experiência, em uma pesquisa infantil. Uma pesquisa com imagens, com imagens infantis, que procura ver as imagens infantilmente com um olhar desprovido, desnudado das representações e interpretações, que não procura verdades, mas encontra potências do pensamento infantil.

No segundo momento, "Vestígios de infância", busco pensar as marcas principais do que constitui uma ideia de infância que tem sido fundadora em nossa tradição: a maneira dominante de pensar a infância como ser que será, como ser incompleto e incapaz. Para em seguida apresentar uma outra ideia de infância: a infância já não como idade cronológica, como etapa de vida pré-estabelecida, mas pensá-la a partir do que ela tem, como presença, como 
afirmação, como força, instaurada em uma temporalidade imensurável, a infância como devir, como possibilidade de mudança, como experiência, experiência em vida, vida em experiência, ou seja como condição humana. Aqui um texto não tão infantil, não tão criança, composto primeiramente, ainda preso a algumas amarras, mas que apresenta um pouco a própria transformação desse ensaio em uma composição que vai se abrindo e sendo atravessada pelas sensações, percepções, afetos, afectos e perceptos.

Já no terceiro momento dessa composição, "Rastros de proporções crianceiras”, interessa-me pensar a infância, ou não-lugar inquietante. A criança não habita um outro lugar. Mas coexiste no mundo com suas vivências, seus saberes, suas imagens, seus desejos. Se houvesse mundos, diria que a criança, coexiste junto conosco. Penso aqui também, o corpo, com o corpo. Corpo que provoca o pensamento, que dá o que pensar, que afeta, toca, sensibiliza outros corpos, corpos sensíveis a outros corpos, num encontro íntimo provocador do pensamento.

Já no quarto momento, me dedico a pensar em "Delírios irracionais da imaginação", meus, da infância, das crianças, das imagens infantis. Falo de uma tartamática infantil, de uma infânciomática inquietante. E se em vez de subjetivar, identificar a matemática, ${ }^{2}$ dessubjetivasse-a, adjetivasse-a? É um pensar e experimentar infantil que as crianças, o devir-criança que faz pensar: o que a matemática, como forma, como identidade, colocando-se em devir, em devir-criança pode desdobrar? Invenção? Experimentação? Encontros? Esquecimento? Amizade?

Para além dessa intenção, esse texto se apresenta como um convite, um convite a pensar com a infância, as crianças, as imagens produzidas pelas crianças, os autores

2 Falamos de uma matemática praticada na educação de modo geral e na escola de modo particular. 
que trago para junto pensarmos, para com elas e com eles pensar, quem sabe para além delas e deles. Espero que possamos olhar as imagens, as falas e os pensamentos infantis e pensar com eles tendo uma experiência sensível com a infância, com as crianças, com as imagens infantis, deslocando nosso olhar e pensamentos da psicologia e da pedagogia. Assim, digo, ajudada por Kohan (2007, p.137): "Será uma alegria se algo da escrita a seguir nos permitir falar o que não falamos, pensar o que não pensamos, olhar o que não olhamos".

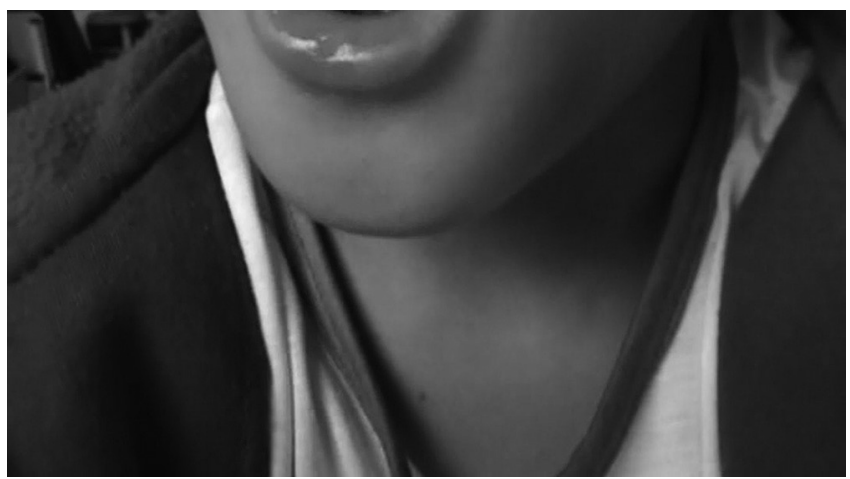

(Pré II, 2012, 15 9)

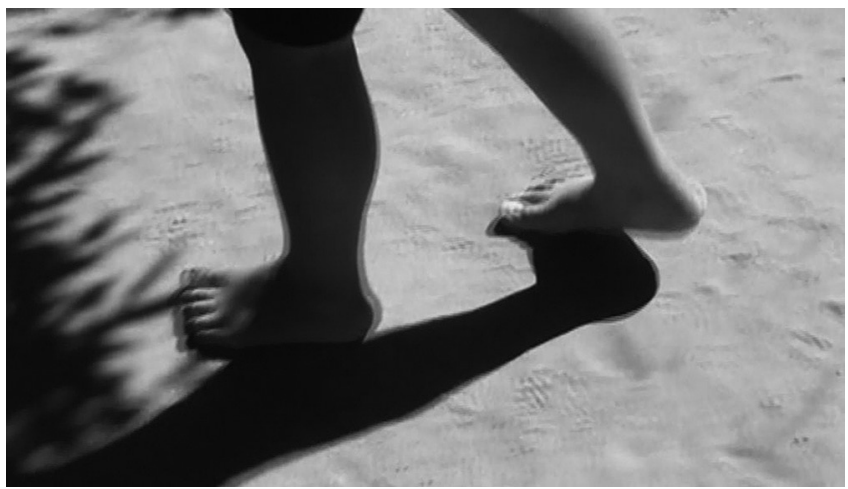

(Pré II, 2012, 20 7)

Fonte: https://www.youtube.com/watch?v=76CDjh0Ihx8 


\title{
1 \\ Penteando e desarRumando a PESQUISA
}

\author{
Se rodá, fica rodando o céu! \\ Olha, faz também! \\ Que massa!
}

(Pré I, 2012, $3^{\circ}$ 20)

\section{Palavras apenas.... Palavras pequenas... Palavras, momentos... Palavras...}

Iniciarei essa composição com o fragmento do conto de Clarice Lispector (1998, p.62): "Criava as mais falsas dificuldades para aquela coisa clandestina que era a felicidade. A felicidade sempre iria ser clandestina para mim". Foi por meio dos contos de Clarice Lispector, "Felicidade clandestina" e "Cem anos de perdão", com uma narrativa inebriante, que me vi e vivi a experiência de busca da menina pelo livro e pela rosa desejada. Lancei-me, por meio dessa leitura, rumo ao que seria desejado, incerto, inseguro, clandestino. O desejo pelo novo e (des)conhecido me impulsionava em uma busca que sinalizava mais para uma travessia, um percurso, do que para um ponto 
de chegada. Instituída de uma intencionalidade a priori, que, rigorosamente acreditava, me levaria ao encontro da infância por meio da pesquisa, com o sentimento de (in)certeza, pela posse do livro, "guiava a promessa do livro, nos dias seguintes", acreditei que poderia medir, quantificar, prever, encontrar um caminho seguro, criar instrumentos de medição e um método que quantificasse, dando lugar ao experimento fechado, limitado. Entretanto, inevitavelmente, precisaria arriscar-me mais rumo à aventura $d a$ infância, ora como condição humana existente em mim, ora como a infância das crianças, ora como a infância da escrita que se constitui aqui, ora como a infância da pesquisa.

Com um sentimento parecido com o das meninas de Clarice Lispector que se lançavam frente ao caminho para obter o objeto de desejo, mesmo que esse trilhar fosse incerto, cheio de medos, suspense, ansiedade, mas também de deslumbramento e subversão diante do livro e da rosa desejada, agora era eu que precisava permitir-me adentrar em um território "infância, onde medos, dúvidas, sensações, ideias, diálogos e encontros, fizessem circular medos dúvidas, sensações, ideias, diálogos e encontros" (Leite, 2011, p.25). Mas seria eu capaz de me arriscar por um percurso tão incerto? De abrir-me à experiência, à subversão da ordem, a virar-me pelo avesso, a libertar-me das minhas "verdades" e a profaná-las, como fizeram as meninas de Clarice?

Fiquei feito boba, olhando com admiração aquela rosa altaneira que nem mulher feita ainda não era. E então aconteceu: do fundo do meu coração, eu queria aquela rosa para mim. Eu queria, ah como eu queria! (Lispector, 1998, p.60)

Assim, passei a perceber que, ao procurar um campo de pesquisa para a composição dessa escrita com caminhos 
e metas definidas e traçadas, o que encontrava era um chão que havia se despedaçado, e nessas fendas, nessas aberturas precisava lançar-me, constituir-me, enredar-me. Era necessário não contentar em lembrar, inventar, recriar, mas também, desejar, sentir, experimentar e embarcar em uma viagem rumo ao desconhecido, experienciando novos estados.

Caminhando com Clarice e suas meninas, observei que a infância em "Felicidade clandestina" e "Cem anos de perdão” (Lispector, 1998) configura-se como (re)invenção e como possibilidade de um devir. Elas me convidavam a deslocar-me, afetar-me, a sair da condição imobilizante que hora me encontrava, posta pelo olhar adulto, pelo ser adulto. Elas me provocavam a subverter a ordem, as regras, as normas, como fez a menina em "Cem anos de perdão”. Provocam a entregar-me à infância. Ser afetada, tocada, atingida por ela. Desloquei então meu olhar para um espaço onde a infância pulsa vibrante, a Educação Infantil. Para isso necessário se fez, além do deslocamento do olhar, retornar a esse lugar, infância/educação infantil, no qual estive durante alguns anos como professora, porém, com um olhar quase sempre voltado para o ensinar e o aprender. Um olhar voltado para o como e quando fazer, era quase, uma ditadura do como e quando, na busca de controlar todas as variáreis do trabalho docente.

Nesse retorno, lembrei que minhas inquietações e perguntas centravam-se mais no ser professora, na prática docente: por que as crianças que frequentavam a educação infantil durante três anos chegavam ao final sem estarem alfabetizadas? Por que no trabalho com crianças de cinco anos repetia-se a mesma proposta curricular desenvolvida com as crianças de quatro anos? Por que tinha que repetir tudo o que tinha feito no ano anterior com as mesmas crianças, da mesma forma? Por que as crianças, ao contarem, pulavam alguns objetos ou os contavam duas vezes? 
Para que fazer exercícios de pintar dentro e fora, em cima e embaixo, se os pequenos já sabiam isso? Todos os porquês iam em direção do saber fazer, saber ensinar, no qual muitas vezes privilegiavam uma verdade sobre todas as coisas, sobre o mundo. Já como professora no ensino superior, longe física, mas não afetivamente das crianças, atuando com a disciplina de Fundamentos e Prática da Educação Infantil e no Grupo de Pesquisa em Estudos Pedagógicos, observei durante as conversas em que infância, criança e educação infantil estavam presentes, inquietações, medos, ansiedades e angústias em relação ao quê, como e quando ensinar. Mais uma vez o olhar estava direcionado para o conteúdo e a forma e não para as crianças que nos cercavam, para os afetos disparados na relação com elas, para as potências e as possibilidades. Era um pensar para técnica, para o molde, para o estabelecimento de leis e a melhor maneira de cumpri-las, e não um pensar para e com os estados e as sensações.

Então, provocada pelo professor César Donizetti Pereira Leite, pelas meninas claricianas e por novas leituras (Kohan, 2005, 2007; Agamben, 2005, 2007; Larrosa 2002, 2010), lançava-me na aventura de ouvir, observar e olhar para e as crianças, na busca do que me afetasse, me tocasse, me atingisse e me provocasse. Na medida em que me lançava nas leituras e no movimento de pensar a infância, fui sendo afetada pelo que esse encontro me despertava. Ao me entregar, sobretudo às leituras, fui constituindo outras possibilidades de pensar a infância por um caminho até então desconhecido. Nessa direção, inserida no espaço da educação infantil, fui sendo afetada pelas coisas que via e ouvia, fui observando que:

- o espaço da educação infantil é transformado em espaço com características de um ensino fundamental; 
- as crianças realizam sempre as mesmas atividades, quando essas são direcionadas por um adulto;

- há controle em relação às crianças, principalmente quando elas estão em sala de aula e no refeitório;

- o trabalho individualizado é muito valorizado;

- o trabalho com a matemática centra-se na denominação das formas geométricas (triangulo, retângulo, quadrado e círculo), nos números de zero a nove, por meio da oralidade (a professora fala, as crianças repetem - crianças aprendem);

- as crianças veem as mesmas coisas, da mesma forma, nos três anos consecutivos na educação infantil.

- quem dá conta da tarefa é parabenizado pelo sucesso individual e quem não dá, não a chega ser ridicularizado abertamente, mas é público o fato de não ter feito a tarefa do jeito que "deveria";

- o jogo é utilizado como recurso didático e está, quase sempre, relacionado à temática do sistema de escrita;

- trabalho centrado nos "conteúdos" descritos no planejamento anual: acabou os "conteúdos" não tem mais o que ensinar;

- a organização da escola, da sala, das coisas, é centralizada nas necessidades dos adultos e não das crianças;

- algumas crianças já são rotuladas com dificuldades de aprendizagem.

Entretanto, sentia-me incomodada, parecia que eu traía meu olhar, que ainda não estava vendo, que o olhar me escapava. Para arriscar-me a deslizar por um caminho fluído, aquoso, para olhar a infância, para ser atravessada pela infância, precisaria romper com a "herança", com tudo que era demasiado pesado, deixar pela estrada as 
coisas que me impediam, seguravam, asseguravam, acorrentavam. Era preciso abandonar o cais, o porto seguro de águas tranquilas, recolher a âncora, precisava não só me sentir clandestina, mas me tornar clandestina, atuar na clandestinidade, como as meninas de Clarice. Foi com essa sensação de clandestinidade que pensei em:

- compreender as relações existentes entre infância e experiência matemática na educação infantil;

- investigar na dinâmica dos espaços da educação infantil o que escapa aos olhos da professora, buscando identificar os modos de tradução das profanações infantis;

- entender de que maneira as crianças fogem de experiências sem sentido e significado para elas, como elas ressignificam essas situações e como produzem seus significados;

- identificar as linhas de fuga que as crianças utilizam para escapar criar, inventar e recriar outros e novos sentidos para as experiências matemáticas.

A sensação de clandestinidade persistia, grudava-me como uma gosma cada vez mais crescente. Ao adentrar o espaço da educação infantil em busca do registro, da captura do que posteriormente seriam os "dados" da pesquisa, sentia-me novamente ocupando um espaço que não residia mais. Medo, insegurança, desconforto, incerteza me assolavam. Colocar crianças de quatro a cinco anos para fazerem os registros por meio da filmagem, inicialmente foi apavorante. Às vezes fui acometida por um verdadeiro pavor. Perguntava-me inicialmente: será que isso dará certo? O que encontrarei nos registros delas? E se eu não encontrar algo para pensar a matemática?

Então, em nove meses, de abril a novembro, duas vezes por semana, durante duas horas com cada grupo 
de criança, ora pela manhã, ora à tarde, crianças, professoras e eu nos encontrávamos para vivenciarmos alguns momentos juntas. As crianças utilizavam a câmera ora como artefato que filma, capta a imagem, ora como um brinquedo, ora como um simples objeto em suas mãos. As imagens, produzidas pelas crianças longe do olhar direcionado do adulto, apresenta momentos em que elas focavam o vazio, o chão, o nada, o grupo que brinca, a singularidade da natureza, ou simplesmente olhavam, filmavam sem se prenderem ao que estavam filmando. Falavam e faziam coisas que perto do adulto ficariam inibidas de falar e fazer, brigavam, imitavam situações em que a câmera estava presente(jornal), exploravam a câmera com elas mesmas (explorando seu corpo), se olhando, fazendo caretas. Muitas vezes parecia que a câmera era parte do corpo, era o próprio corpo.

Quanto ao uso do artefato, revezavam-se para escolher quem seria a próxima a usar a câmera, cantavam o verso "Mamãe mandou eu escolher esse daqui. Abacaxi, não faz xixi na cama do Didi”, ou anunciavam simplesmente quem seria a próxima da vez. Orientavam entre si o uso do instrumento. Algumas vezes, para algumas crianças, brincar era mais importante do que operar a máquina. Foi ora operando, ora brincando, ora simplesmente segurando uma coisa qualquer em mãos que as vivências e as experiências das crianças foram filmadas, mesmo que, na maioria das vezes, elas não tivessem intenção de fazê-lo.

Eu fiz assim, eu fiz assim, eu aperto aqui fica longe, se eu fiz assim eu vejo você perto.

Olha se eu rodá, rodá, rodá, fica rodando o céu!

Eu to com dor de mão.

Eu to vendo você de longe. O que isso sineguefica? Pergunta-me ao ver a imagem embaçada.

A minha mão tá muito mole. 
Agora deixa eu camerar!

Filma eu! Faz um quadrado das caras. (Pré I e II, 2012)

Pensava eu, de posse das imagens, das filmagens feitas pelas crianças, que percorreria um caminho menos íngreme, menos sinuoso, menos duvidoso. Ledo engano. Muitas dúvidas e incertezas habitavam sempre o meu silêncio, interrompendo-me e me perguntando: qual direção tomaria? Ao mesmo tempo em que me sentia ameaçada pela incerteza, a mesma incerteza me seduzia, me fascinava, me atraía cada vez mais a lançar-me rumo ao desconhecido. Sentia-me a própria menina de Clarice (Lispector, 1998, p.10) diante do objeto de desejo: "Era um livro grosso, meu Deus, era um livro para ficar vivendo com ele, comendo-o, dormindo-o e completamente acima de minhas posses". E eu podia me colocar a caminhar, me colocar a trilhar o percurso sem rumo, sem ponto de chegada, e dizer como disse a menina de Clarice (Lispector, 1998, p.11): "é tudo o que uma pessoa, grande ou pequena, pode ter a ousadia de querer".

Então, mais uma vez instigada pelo professor César Leite, pelas conversas no grupo I-m@go, ${ }^{1}$ pelas leituras (Kohan, 2005, 2007; Rancière, 2009, 2012; Agamben, 2005, 2007; Larrosa, 2002, 2010; Deleuze, 1997, 2011; Deleuze; Guattari, 1992, 2010) desloquei meu olhar para as produções imagéticas das crianças em busca do que me tocasse, do que me afetasse, do que mexesse comigo, do que me proporcionasse borbulhas no estômago. As imagens produzidas pelas crianças convidavam a pensar, convidavam a pensar a infância e a criança, convidavam a pensar, nesse emaranhado de coisas, a matemática. Mais que isso: ajudada pelos trabalhos do professor César

1 Laboratório da Imagem, Experiência e Criação da Unesp, campus de Rio Claro. 
Donizetti Pereira Leite, a produção de imagens por crianças me convidavam a pensar em uma pesquisa que não fosse previamente traçada, que não fosse previamente pensada, que não fosse previamente objetivada, mas me levava a pensar a pesquisa como experiência.

Mais uma vez a falsa seguridade abalava-se, pois a pesquisa aqui não era mais um lugar seguro, de reflexões sobre e a partir de, lugar onde lemos as imagens, interpretamos os dados e os analisamos. Mas se constituía como um lugar incerto, pouco preciso, pouco objetivo, lugar onde tentamos pensar com as imagens, pensar com a infância, pensar com as crianças, pensar com as sensações. Uma pesquisa retirada do previsto, do calculável, um lugar de abertura, um lugar de vertigem, de corpos que se misturam, que se melecam, se lambuzam, se gosmeiam, de corpos que se encontram, uma pesquisa que se constitui como experiência, uma pesquisa infantil, uma infância da pesquisa, pois "pesquisar com crianças é um convite à abertura, ao deslocamento de lugares e tempo" (Leite, 2011, p.115).

$\mathrm{Na}$ quase (in)certeza de que portava um objeto ilegal, lancei a cometer a maior das infrações: distanciar-me, como diz Agamben (2005), do projeto que funda a ciência moderna, a expropriação da experiência. Ou seja, distanciar-me da busca por um caminho seguro, dos instrumentos de medição, da quantificação das impressões sensíveis, da homogeneidade, do consenso, do genérico, do que pode ser estruturado, aplicado e mesmo previsível. Arriscar-me sem rumo à abertura do novo, ao desconhecido, ao que será dado a conhecer, mesmo perguntando-me infinitamente, afinal de contas para onde vou? "Quem sou eu? Ah esse é o grande enigma!" (Carroll, 2002, p.21). Fui povoada, então, por uma infindável felicidade, uma infindável felicidade clandestina, "não era mais uma menina com um livro: era uma mulher com seu amante" (Lispector, 1998, p.12). 
Vai logo que a bateria tá acabando, bateria tá acabando vai logo.

Oh! Três minutos pra bateria acabar, três minutos.

Começa logo, agora dois segundos, dois minutos. Tá acabando a bateria? Tá, só um minuto agora! ${ }^{2}$ (Pré II, 2012, 11요

\section{Intimidade ex-posta}

A pesquisa com infância, com crianças, uma pesquisa como experiência, convida para travessias que inquietam, bem para além da última curva do rio e levam a pensar a intimidade, a intimidade das coisas, com as coisas, do mundo, com o mundo, dos seres, com os seres. Em um de seus poemas, Manoel de Barros (2010, p.67) nos diz: "A gente descobre que o tamanho das coisas há de ser medido pela intimidade que temos com as coisas [...]. Assim, as pedrinhas do nosso quintal são sempre maiores do que as outras pedras do mundo. Justo pelo motivo da intimidade". Poderia dizer que as pedrinhas do quintal em Manoel de Barros são tanto maiores e maiores que as maiores pedrinhas do mundo, mesmo sendo menores justamente pela relação íntima entre o poeta e a pedrinha, e as pedrinhas. Parece que as pequenas coisas, as coisas pequenas, as coisas minúsculas são enormes quando a habitamos, quando a conhecemos com profundidade, quando olhamos sua interioridade.

2 Disponível em: <https://www.youtube.com/watch? $\mathrm{v}=\mathrm{dVrc}$ VTn6I0g>. 
No mundo em que vivemos a intimidade está normalmente ligada com os sentimentos de afeto entre pessoas em um relacionamento. A intimidade nos leva a ações e a sensações muitas vezes impulsivas: correr para o abraço, correr ao encontro, desejo de estar sempre perto, sempre junto, ser atrevido e ousado, agir impulsivamente; e outras nem tanto: trocar confidências, descansar recostado no peito ouvindo o coração bater, compartilhar coisas que normalmente não compartilhamos com outras pessoas, correspondência entre olhares e gestos. A intimidade cria laços e vínculos, sustenta relações, gera um elo, um contato, uma tensão, um movimento. Propicia proximidade e cumplicidade, um caminho possível para conhecer o outro, os seres, as coisas, o mundo. Entre afetos e sensações a intimidade permite que você toque com os olhos, com a pele, com as mãos, com o gesto, com o corpo, com as palavras desengavetadas.

Pensar em intimidade é pensar em relações, em aproximações, em interioridades, em profundidade, em afinidades. A intimidade parece ser algo que de alguma forma está entre as coisas, entre o mundo, entre os seres; tangencia os seres, invade espaços, dispara afetos, e ao mesmo tempo nos oferece um olhar onírico das coisas, um olhar invertido das coisas. É também postuladora de devaneios, pois, já nos dizia Bachelard (1990, p.11) "são os devaneios que nos dão todos os tesouros da intimidade das coisas". A intimidade é a descoberta de um mundo escondido, no qual entramos sem cerimônia, com uma frase de acolhimento, onde um universo nos é revelado, e "vemos o avesso das coisas, a imensidão íntima das pequenas coisas" (ibidem, p.12).

Olha aqui a mãe, a mãe formiga!

Aqui as formigas, as formigas aqui!

Ta vendo elas Raissa, ta vendo elas?

Ele pego, eca, é uma bolinha. 
Não pode comer barata, que nojo!

Coitada da baratinha!

Gava ela, gava, gava ela pra gente vê.

Tá vendo ela? Aqui, aqui!

Ah, não dá!

Vamos achar aranha gente, vamos achar aranha!

Já to ficando enjoado.

Vamos achar a casa da aranha!

Mas cadê a dona baratinha?

Vamos ver o pauzinho, se ele tá mais gande! (coloca o pauzinho na frente da lente da filmadora)

Haha!!! Ele tá gande!

(Pré I, 2012, 5² 7)

O olhar de intimidade escapa à passividade da visão. É uma certa intimidade que se intensifica quando o desejo de olhar alia-se à imaginação criadora, inventiva, pois ela potencializa os detalhes, o menor, o pequeno, o ínfimo, o que se esconde, as pequenas coisas que não se vê, não se percebe de imediato, até mesmo o oculto. É o modo como olhamos as coisas, os seres, o mundo. Para ver as miudezas, aquilo que é minúsculo, aquilo que habita a interioridade das coisas é preciso estar à espreita, vigiando, sensível ao encontro, atento àquilo que se passa entre as coisas, entre os seres, entre o mundo, com um olhar aberto para ver o que não é visível, o que não está dado, para se espantar, se encantar, delirar, imaginar, porquanto, nos dirá Bachelard (1990, p.14), "a imaginação é uma louca esperança de ver sem limite”. Por meio da intimidade é possível expor-se, desnudar-se, desarmar-se, fragilizar-se, fortificar-se, perder o pudor, a vergonha, o brio. Uma pessoa de intimidades (com ela, com os outros, com outros corpos) é uma pessoa exposta, que se coloca ao sabor de experienciar novas coisas, novas aventuras, por isso, uma pessoa que corre riscos, que pode estar sempre em perigo. 
A intimidade está relacionada à própria exterioridade do ser, quanto mais íntimo posso ser, mais me exponho, mais vulnerável me torno diante do outro, por isso, ela tem a ver com entrega, com confiança, com afinidades, com ousadia, com acolhimento: a intimidade é a própria exposição. Tem algo na relação com outro que nos permite desnudar-nos, expor-nos, que desperta um sentimento de confiança. Seria como se um ímã atraísse, com uma força em sentidos divergentes ou convergentes. Ora me manifesto, ora me escondo, ora me fecho, ora me abro, esses movimentos de fechamento e abertura, diz Bachelard (1978, p.342) "são tão numerosos, tão frequentemente invertidos, tão carregados de hesitação, que poderíamos concluir por esta Fórmula: o homem é um ser entreaberto". É nesse entre, entre um jogo de forças, que nem é da ordem do dentro, nem tampouco da ordem do fora, que tenciona a ideia de pesquisa e intimidade. Ou seja, pensar intimidade e pesquisa, e ainda uma pesquisa experiência, uma pesquisa infantil, não é dizer de um mundo de intimidade, de colocar-me sempre à vista, sempre intimamente, de maneira profunda, interiorana e pessoal, mas se fazer atravessada, para ser atravessada pela infância, pela infância do mundo, pela infância das crianças, fazendo-me sair dos limites, para diluir em composição com esse mundo infantil a mim apresentado.

Pensado nisso, enquanto as crianças se esbeiravam, se encostavam, se roçavam, se expunham, professoras e eu, procurávamos nos aproximar. Mesmo elas abrindo as portas da sala de aula o desconforto pairava no ar. Não saberia dizer se o desconforto maior era meu ou delas, somente que ele existia e era real. Eu era estrangeira naquele lugar. A sensação de que invadia um espaço se atenuou ao longo dos oito meses em que estive na escola. Mesmo dizendo que meu olhar se direcionaria para as crianças, elas pressentiam, sabiam interiormente, que 
seria impossível não se exporem. Era como se eu não tivesse permissão para violar os segredos ocultos daquele espaço, era como se eu fosse ver o que não deveria ser visto: a prática docente, as ideias, a relação com as crianças; era como se as intimidades estivessem sendo "reveladas", questionadas ou até mesmo ameaçadas. A intimidade também pode ser protegida: dou espaço ao outro, permito que o ele me invada até onde desejo que me veja, me olhe, me desvende, me desnude, tal como o espaço do armário, em Bachelard (ibidem, p.248), no qual somente o que é permitido é colocado dentro, pois "o espaço interior do armário é um espaço de intimidade, um espaço que não se abre à toa". Conforme os vínculos e a proximidade foram se constituindo, o distanciamento tornara-se menor, parecia às vezes haver uma certa empatia no ar. Parece que diante da intimidade ameaçada elas tentavam restabelecer sempre o "equilíbrio" do espaço habitado, isso diminuía o meu desconforto, a minha tensão, os meus conflitos, por ocupar um lugar que não era meu.

De certa maneira éramos cúmplices da inseguridade que nos habitava, talvez essa cumplicidade nos aproximava e permitia aproximar-me das crianças, e com isso a estrangeira foi sendo acolhida. Contudo, foram elas, as professoras Chronilda ${ }^{3}$ (formada em Pedagogia, e com 23 anos de atuação só na educação infantil) e Chronalda (pedagoga, com 5 anos de docência, todos na educação infantil), responsáveis pelo contato com os pais, pelo consentimento dos pais com a filmagem das crianças, até mesmo atuando no convencimento de alguns. Mas, o desconforto, a sensação de estrangeiridade diminuía quando as crianças ocupavam os espaços abertos (área coberta, parque de areia, área descoberta), fora das quatro paredes

3 Os nomes das professoras, das turmas de crianças do pré-escolar I e II, foram escolhidos em homenagem a Khronos, deus do tempo. 
(sala de aula e refeitório), o que ocorria todos os dias depois da primeira hora e meia de aula, pois as crianças rompem com a estrangeiridade das coisas, das relações, dos espaços, dos afetos.

Parece que com crianças, com as crianças desse trabalho, crianças de quatro a cinco anos, a intimidade se instalou como um imã que atrai em sentido positivo. Parece que as crianças são dadas a intimidades. Elas, as crianças me apresentam infinidades de intimidades, é impossível falar e pensar nas crianças e em intimidade, sem falar e pensar nas multiplicidades de sensações, afetações e sentidos que elas me provocaram, me provocam. As crianças pareciam grudes, chicletes, pois era somente adentrar ao recinto da escola, da sala de aula e vinham alvoroçadas em minha direção, se encostando, se recostando, se aninhando por perto. Olha o que eu trouxe! Olha a minha agenda! Olha, eu me machuquei! Olha o meu carrinho! Olha, eu tenho maquiagem! Olha, eu fui na festa! Olha o que eu encontrei!

As crianças nos convidam a olhar, a olhá-las. Poderia dizer que esse é um convite à intimidade. Um convite a enxergá-las, a enxergar o mundo com a sensibilidade própria da infância, da criança. Sentia-me, todo o tempo, convidada a compartilhar suas descobertas, seus achados, suas curiosidades, seus medos, seus anseios, suas alegrias, suas raivas, suas impaciências, seus desgostos, suas insatisfações. É um convite a retornar à infância, à infância das coisas, à infância dos seres, a infância do mundo, à infância da língua. Quem vai camerar hoje? Deixa eu camerar! A minha mão esta doendo de mole! Chegou o filmador! Filmeimagdol! Somente a proximidade entre os seres, as coisas e o mundo abre a possibilidade de vermos o quanto misteriosos são os nossos mistérios.

As crianças provocavam uma relação íntima, efetiva, afetiva não só com o ser pessoa, mas com as coisas. Ou seja, 
os corpos-crianças de posse da câmera filmadora, para que filmassem sem orientação prévia de minha parte, sem roteiro, parece que eram sugados, misturados pelo corpo-câmera, tornando assim, outros corpos. Como nos diz Leite (2013, p.9) "corpos produzindo corpos outros, são corpos derivando nas câmeras, das câmeras, são corposcâmeras se produzindo em camerascorpos, corpos zooms, corpos quebras, corpos cenas, corpos montagens". A intimidade das crianças com a câmera filmadora era tamanha que muitas vezes, tanto nós, quanto elas confundiam-na com o próprio corpo, levando-as às vezes a não saberem com que mão pegar, a errarem ao se tocarem, era como se na bagunça de corações, o sangue errasse de veia e se perdesse nos apresentando uma intimidade infantil. Uma intimidade que nos apresenta a câmera sendo usada como extensão do próprio corpo. Ela desaparece como equipamento de filmagem e aparece como corpo, corpo que explora e descobre o espaço, o tempo, o mundo, os seres.

Desnorteada, pois, já confundia tantas pernas que não sabia (e ainda não sei) qual caminho seguir, como poetisa Chico Buarque de Holanda (2006), com um olhar que não mais verificava, mas que se espantava com o que se abria diante dele; fui me lançando, me entregando, me afetando, até mesmo me perdendo no que surgia, no que emergia das experiências vividas pelas crianças, fui sendo atravessada pela infância que habita as crianças. Mariano (Couto, 2003, p.46), nos diria, "Dormir com alguém é a intimidade maior. Não é fazer amor. Dormir, isso que é íntimo. Um homem dorme nos braços de uma mulher e sua alma se transfere de vez. Nunca mais ele encontra suas interioridades". E foi assim que, "dormindo" com as crianças, com a infância, com as imagens me des-achei de minhas interioridades, me des-achei de mim mesma, me des-achei no e pelo caminho. Minha intimidade foi invadida, foi violada. Dei para ter desvarios, devaneios, 
delirar. Vida existida por excelência, transbordada, vazada, evidenciada, exposta, mas, quem sabe, igualmente compartilhada pela intimidade com os espaços, com os tempos, com o mundo.

Se ao te conhecer, dei pra sonhar, fiz tantos desvarios

Rompi com o mundo, queimei meus navios

Me diz pra onde é que inda posso ir

Se nós, nas travessuras das noites eternas

Já confundimos tanto as nossas pernas

Diz com que pernas eu devo seguir

(Holanda, 2006, p.299)

As produções imagéticas das crianças são um convite à intimidade; convidam-nos a entrar nela, a entregar-se a ela sem reservas, a invadir seu espaço, a arrebatar-se, a deslumbrar-se, a excitar-se, para com isso, possamos juntos, com ela, delirar, variar, ir para além dela. As imagens infantis nos exigem um envolvimento íntimo, um abandono, uma entrega infantil. Convidam-nos a pensar com elas. Pensar com as imagens, pensar além delas é olhar atento, é deslocamento, são outras travessias. Olhá-las, pensar com as imagens infantis não é criar um campo onde estão ali para analisá-las, interpretá-las, mas recolher-se na intimidade daquilo que dá o que pensar. É demorar-se nisso. Pensar com e para além delas é entrar e demorar, se perder na profundidade ou como diz Larrosa, (2010, p.142) “[...] é trazer o dito à proximidade do que fica por dizer, trazer o pensado a proximidade do que fica por pensar, trazer o respondido a proximidade do que fica por perguntar". É nos desprendermos de nós mesmos, numa atenção estendida quase até o "limite que paradoxalmente, coincide com uma máxima intimidade com nós mesmos” (Larrosa, 2010, p.48). 
Os encontros não foram somente com as professoras, com as crianças, com as infâncias, com as infâncias das e nas crianças. Aproximei-me, fui afetada, tocada e também atravessada por ideias e pensamentos, entre eles destaco os pensamentos de Leite $(2011,2013)$ - meu primeiro enamoramento, Deleuze (2011), Agamben (2005), Kohan (2005, 2007), Rancière (2009, 2012), Bachelard (1978, 1990), Barros (2010, 2013), Gallo (2009), os quais me possibilitaram estabelecer uma conversa com a infância, com a criança, com a matemática e com a educação. Esses encontros fizeram gerar ainda uma intimidade minha com eles? Acho que ainda não. Entretanto... a intimidade começa com encontros.

A ciência pode classificar e nomear os órgãos de um sabiá, mas não pode medir seus encantos.

A ciência não pode calcular quantos cavalos de força existem nos encantos de um sabiá.

Quem acumula muita informação perde o condão de adivinhar: divinare.

Os sabiás divinam. (Barros, 2013, p. 316)

Dessa maneira, as produções imagéticas das crianças como convite a abertura, à intimidade são movimentos de criação, movimentos de imaginação, de devaneios e muitos delírios. São imagens que nada dizem ou dizem muito, imagens incômodas, vertiginosas, enjoativas, desfocadas, embaçadas, vazias, escuras, cansativas, trêmulas, paradas, corridas, rápidas, lampejos de imagens, mas que nos convidam a pensar com elas, para além delas. As produções imagéticas nos convidam a pensar a partir do exercício do olhar das crianças, possibilidades de pensar a infância, a criança e a matemática com um olhar criança, de descoberta, de invenções, de criações e com isso, com as imagens infantis, pensar algumas travessias do universo infantil. 
Fui então provocada a pensar no corpo, nos corpos, corpos que pulsam, corpos que pensam, corpos como potência, potência de vida. Corpos coexistindo no mundo em uma conosco em uma intimidade inebriante. Fui também incitada a pensar em uma matemática que está na origem, na origem das coisas, do mundo, na origem do pensamento, e por isso está no começo, por isso, incompleta, por isso, experiência. Ligada a despropósitos, ao jogo, à brincadeira, às fabulações e às profanações. Uma matemática que me parece opera em outra lógica, quem sabe sem lógica, quem sabe ainda opera em outra coisa que não seja necessariamente lógica.

\section{Todos os caMinhos, neNhum caminHo... eXperiência}

Tomarei como ponto de continuidade dessa composição o poema de Manoel de Barros, ele me provoca a pensar a pesquisa, a experiência e a infância. Parece-me que o poeta pantaneiro questiona a validade da razão, desmistifica a ciência como discurso supremo e sua visão alimentada estritamente pela objetividade da realidade. Ao dizer que "a ciência pode classificar e nomear os órgãos de um sabiá, mas não pode medir seus encantos," Barros estaria perguntando à ciência como técnica impotente diante de um ato maior: o divinare? É a proximidade com as coisas pequenas, com as coisas desimportantes, com a natureza, com as coisas do chão, que normalmente não chamam a atenção que Barros nos apresenta uma possibilidade de olhar o mundo com uma lente desobjetiva. É essa intimidade intensiva de experiência, essa proximidade com as coisas, esse olhar sensível que o faz transgredir o pensamento racional.

Agamben (2005) e Benjamin (1994) indicam o empobrecimento da experiência na modernidade e a fuga do 
homem moderno a experienciar qualquer coisa. Mesmo cercados na vida cotidiana por uma série de eventos, estamos quase sempre alheios ao que nos passa, ao que nos toca, ou seja, nenhum deles torna-se experiência. Benjamin (1994, p.116), nos diz ainda, a pobreza de experiência impede o homem "a partir para frente, a começar de novo, a contentar-se com pouco, a construir com pouco, sem olhar nem para a direita nem para a esquerda". O homem moderno, para Benjamin, não aspira por novas experiências, pelo contrário, ele quer libertar-se de qualquer acontecimento, de qualquer encontro, de qualquer situação em que possa ser tocado, afetado.

Será que com isso, nos escondemos por trás de máscaras que nos protegeriam de nós mesmos, da nossa pobreza interna e externa, da nossa impenetrável e inexpressiva vida? Parece que a ausência de experiências dociliza nossos corpos e nossos pensamentos tornando-nos inertes frente à vida, frente ao mundo, frente às coisas e aos seres. Benjamin (1994) e Larrosa (2002) postulam que a experiência requer um momento de interrupção, um momento de ócio, requer o desaceleramento rítmico da vida, requer que nos ocupemos das coisas que não podem ser vendidas no mercado, que fujamos do pragmatismo. Sendo que, distantes dessa relação utilitarista da vida, do mundo e das coisas torna-se possível transver o mundo, vê-lo para além do que os olhos naturais podem ver. Neste sentido, Larrosa (2002, p.24) expressa:

A experiência, a possibilidade de que algo nos aconteça ou nos toque, requer um gesto de interrupção, um gesto que é quase impossível nos tempos que correm: requer parar para pensar, parar para olhar, parar para escutar, pensar mais devagar, olhar mais devagar, e escutar mais devagar; parar para sentir, sentir mais devagar, demorar-se nos detalhes, suspender a opinião, suspender o juízo, suspender a vontade, 
suspender o automatismo da ação, cultivar a atenção e a delicadeza, abrir os olhos e os ouvidos, falar sobre o que nos acontece, aprender a lentidão, escutar aos outros, cultivar a arte do encontro, calar muito, ter paciência e dar-se tempo e espaço.

É o distanciamento com a experiência primeira, com a experiência de fonte, com a experiência sensível que acometeu o homem moderno e tanto Benjamin (1994) quanto Agamben (2005), como Larrosa (2002) chamam a nossa atenção. No mundo contemporâneo onde tudo é muito rápido, onde não vivemos mais o tempo presente, nem narramos mais o passado, aonde as informações e as novidades nos chegam cada vez mais velozes e com a mesma velocidade são descartadas e superficiais, onde o trabalho nos ensoberbece e devora todo o nosso tempo, não há tempo para contemplações, para o olhar sensibilizado, para experienciarmos o mundo, os seres, as coisas. "É como se estivéssemos privados de uma faculdade que nos parecia segura e inalienável: a faculdade de intercambiar experiências" (Benjamin, 1994, p.198). O distanciamento do homem à experiência e sua recusa em experimentá-la tem o levado a preferir, como anuncia Agamben (2005, p.23) "que seja a máquina fotográfica a ter experiência delas".

Difícil fotografar o silêncio.

Entretanto tentei. Eu conto:

Madrugada, a minha aldeia estava morta.

Não se via ou ouvia um barulho, ninguém passava entre as casas.

Eu estava saindo de uma festa.

Eram quase quatro da manhã.

La o silêncio pela rua carregando um bêbado.

Preparei minha máquina. 


\section{O silêncio era um carregador?}

Estava carregando o bêbado.

\section{Fotografei esse carregador.}

Tive outras visões naquela madrugada.

Preparei minha máquina de novo.

Tinha um perfume de jasmim no beiral do sobrado.

\section{Fotografei o perfume.}

Vi uma lesma pregada na existência mais do que na pedra.

\section{Fotografei a existência dela.}

Vi ainda um azul-perdão no olho de um mendigo.

\section{Fotografei o perdão.}

Olhei uma paisagem velha a desabar sobre uma casa.

\section{Fotografei o sobre.}

Foi difícil fotografar o sobre.

Por fim eu enxerguei a nuvem de calça.

Representou pra mim que ela andava na aldeia de braços com Maiakovski - seu criador.

Fotografei a Nuvem de calça e o poeta.

Ninguém outro poeta no mundo faria uma roupa mais justa para cobrir sua noiva.

A foto saiu legal. (Barros, 2013, p. 351, destaques da autora)

A experiência tornou-se algo questionável, duvidoso, contestável, uma via incerta para conhecermos o mundo, pois ela origina-se dos sentidos e nada mais insólito, instável e incoerente do que os sentidos, por isso a experiência é condenada. Da desconfiança em relação à experiência nasce a ciência moderna. O caráter tecnicista que se instaura, na e por meio dela, exige previsibilidade, certeza, comprovação, rigor quantitativo, exatidão, caminho seguro e instrumentos de medição, deslocando, como diz Agamben (2005, p.26), "a experiência para fora do homem e entregando-a aos instrumentos e aos números". Com isso, muda-se o sentido de experiência e passa ser sinônimo de experimento, pois este sim é compatível 
com a certeza das exigências científicas, fundamentais ao método científico moderno. Agamben (2005, p.25) ainda diz:

A experiência se ocorre espontaneamente, chama-se acaso, se deliberadamente buscada recebe o nome de experimento. [...] a verdadeira ordem da experiência começa por acender o lume; com este em seguida, aclara o caminho, iniciando pela experiência bem disposta e ponderada e não por aquela descontínua e às avessas; primeiro deduz os axiomas e depois procede a novos experimentos.

O conhecimento adquirido por meio da experiência tradicional (como assim era chamada por Montaigne), não é mais aceito, pois é alcançado através das relações sensíveis do homem com o mundo, e isto é algo disforme, inconstante, irreal e incerto. A busca pela certeza, pelo conhecimento "certo e verdadeiro", pela "verdade eterna", pela neutralidade aproxima a experiência à ciência, ao lugar do método, ao lugar do experimento, a experiência agora é algo calculável, verificável, interpretável, e por assim ser, o conhecimento da razão. Instala-se aqui a unicidade, uma nova relação entre conhecimento e experiência, referindo essas duas esferas a um único sujeito, ao mesmo tempo em que hierarquiza conhecimentos e saberes ao atribuir-lhes valores como racionais e irracionais. Dessa forma, a experiência perde a sua autoridade, como Agamben (2005, p.26) anuncia, "a experiência é incompatível com a certeza, e uma experiência que se torna calculável e certa perde imediatamente sua autoridade. Não se pode formular uma máxima nem contar uma estória lá onde vigora uma lei científica”.

Desde a modernidade o mundo da ciência é o mundo das formas, da construção do conhecimento verdadeiro, da seguridade, da certeza, do método a priori. Parece que 
nesse lugar não há espaço para as incertas, para a experiência, o inesperado, o intempestivo, para a sensibilidade, que atravessa o corpo, o olhar, os sentidos. Mata-se o mistério, a dúvida. Clareto (2011, p.19) nos diz "Em águas sempre-claras-e-quentes, no conforto do translúcido, a razão-luz empreende a pesquisa que categoriza conhecimentos verdadeiros. A representação se presta a essa categorização: ela purifica, reduz as formas a uma identidade". Entretanto, o mundo, os seres, as coisas não são constituídos somente de formas instituídas, mas, pontes moventes, desertos moventes povoados por intensidade e velocidades, onde o tempo e o lugar mais longínquo são aquis e agoras.

Entretanto, mais uma vez, Manoel de Barros nos provoca a pensar as limitações das exigências científicas, quando ele diz "a ciência não pode calcular quantos cavalos de força existem nos encantos de um sabiá. Quem acumula muita informação perde o condão de adivinhar: divinare". A informação anula nossas possibilidades de experiência, de experienciar o mundo; ela, a informação, atrofia a experiência. É a aproximação com mundo, com os seres, com as coisas, é o olhar atento e sensível, é olhar o mundo com uma lente desobjetiva, que possibilita alcançar aquilo que a lente objetiva jamais captura.

É esse olhar desobjetivado, desprovido de perspectivas, de verdades, que Benjamin (1994) e Masschelein (2008, p.37), com um gesto, convidam a ver, a deslocar-me, a colocar-me no caminho, pois, caminhar envolve "ver, abrir os olhos, ter um novo olhar [...] para que possamos ver o que é visível e [...] e para que sejamos transformados". É um convite, ainda, para nos colocarmos como andarilho, como andante, como transeunte, sem ter como ponto um lugar de saída e nem mesmo de chegada, seria o não chegar a lugar nenhum, pois, os lugares demarcam territórios, os lugares, nos dirá Mariano (Couto, 2003, 
p.65), "nos aprisionam, são raízes que amarram a vontade da asa". A busca do andarilho, ser ignorante, é norteada pelo não saber, pela incerteza, pelo imprevisível, pela invenção de novas possibilidades de vivência, porque ele não funda e demarca estradas, mas inventa e desinventa caminhos.

$$
\begin{aligned}
& \text { Todos os caminhos - nenhum caminho } \\
& \text { Muitos caminhos - nenhum caminho } \\
& \text { Nenhum caminho - a maldição dos poetas. (Barros, 2013, } \\
& \text { p.241) }
\end{aligned}
$$

A ideia de experiência, que diz Larrosa, (2002, p.21, $25)$ "o que nos acontece, o que nos toca [...] o encontro ou uma relação com algo que se experimenta, que se prova", nos aproxima da infância, pois é por meio dela que o ser humano se constrói na história. Pela experiência e pela infância estamos abertos ao mundo, como seres inacabados, abertos a modificar-se e transformar-se. A infância, dirá Kohan (2005, p.253), "é devir; sem pacto, sem falta, sem fim, sem captura; ela é desequilíbrio; busca; novos territórios; nomadismo; encontro; multiplicidade em processo, diferença em si mesma; diferença livre de pressupostos. Vida experimentada; expressão de vida; vida em movimento; vida em experiência".

Assim, pesquisar com crianças é um convite à experiência, é um convite a expor-se, a estar em perigo constantemente, é um convite à travessia, a ser tocado e afetado, é um convite a abrir-se a vida, ao mundo, aos seres, às coisas; a habitar outros tempos, outros lugares, outros espaços. É um convite a deixar rastros e marcas, pois habitar, já nos diz Gagnebin (2011, p.60) "significa deixar rastros", do mesmo modo como a lesma deixa seus rastros por onde passa. É um convite ascender ao tartamudo, às experiências primeiras, às experiências de 
fonte, aonde o verbo ainda é virgem. Dessa forma, caminhamos em direção oposta ao caminho seguro da ciência, ao método da ciência objetiva, a triangulação dos dados (eles in-existem?), indo experimentar em outros espaços-tempos, indo ao encontro das incertezas do e no caminho.

Fui andando...

Meus passos não eram para chegar porque não havia chegada

Nem desejos de ficar parado no meio do caminho.

Fui andando... (Barros, 2013, p.48)

Desse modo, uma pesquisa com infância, com crianças, com imagens não poderia ser outra que não fosse uma pesquisa infantil, uma pesquisa criança, uma pesquisa com modos infantis, com perguntas infantis, pesquisa inaugural, de fonte; uma pesquisa que está sempre no princípio das coisas, na primazia das coisas; uma pesquisa que não é dada, que não é, nem será; uma pesquisa que quando dada, dá-se a devaneios, a delírios, a despropósitos, a arrebatamentos; uma pesquisa sempre por vir, uma pesquisa infância. Uma pesquisa nascida dos sentidos, das sensações, das percepções primeiras: primeiro cheiro, primeiro olhar, primeiro gesto, primeiro toque, pensamentos primeiros, primeiro caminhar, primeiro...: como se estivesse pesquisando pela primeira vez, como se fosse começar de novo, sempre de novo, com um olhar distanciado da razão instrumental, da objetivação.

Pesquisar com crianças é estar no meio, na linha, como dizem Deleuze e Parnet (1998, p.70), “[...] na linha de encontro de um mundo interior e de um mundo exterior. Estar no meio", exposta a todos os contactos, a todos os encontros, sensíveis as vibrações. Pesquisar com crianças não se trata de falar por elas ou delas, ou prever uma criança ou mesmo entendê-las. Mas busca uma conspiração, um choque de amor ou de ódio. Não é um 
ajuntamento de corpos, ou uma reunião, ou mesmo uma soma, mas o que acontecem aos corpos quando se reúnem, quando se juntam, quando se encontram. É o que devém desse encontro, dessa composição, dessa produção de um modo de existência, um devir-criança.

No âmago da pesquisa com crianças, da pesquisa que devém-criança, encontramos uma criança enquanto força viva - um devir-criança, há assim, a dissolução, a dispersão da criança-pessoa, como nos diz Schérer (2009, p.203), "a propulsão, se é que se pode dizer, da criança imobilizada sob o olhar dos adultos" para fora do corpo programado, em direção a involuções criadoras. Ela é criada, inventada por força dos encontros e a criação deles leva-nos a fugir da estratificação que impede os fluxos, a escapar da organização extrema e hierarquizada, que tenta a todo o momento, determinar o que pode e não pode ser feito, como e quando agir, como pensar. Ela cria um monte de inesperados, um caminho aberto, no qual não se sabe onde vai dar.

Não se trata aqui de acrescentar um outro modo de fazer pesquisa, mas abrir-se, como diz Deleuze e Guatari (1996, p.21) "[...]às conexões que supõem todo um agenciamento, circuitos, conjunções, superposições, limiares, passagens e distribuições de intensidade, territórios e desterritorializações medidas à maneira de um agrimensor". Trata-se ainda, de colocar-se em movimento ao longo de uma linha arbitrária, permitindo-se expor-se, sair às ruas, deslocar-se dos saberes ditos e dados; um deslocamento do olhar que permite a experiência, não como vivência passiva de ser conduzida, comanda por algo que já está dado, mas como algo que vai se apresentado e nos comandando ao longo da pesquisa, arrastando- nos assim, segundo velocidades e lentidões variáveis num movimento de fuga ou de direções. Em suma, uma pesquisa com crianças, uma pesquisa criança não se define pela ausência de protocolo, 
de modelo, não se define apenas pela existência de uma metodologia indeterminada; ela se define enfim, pela presença temporária, provisória e transitória dos caminhos encontrados.

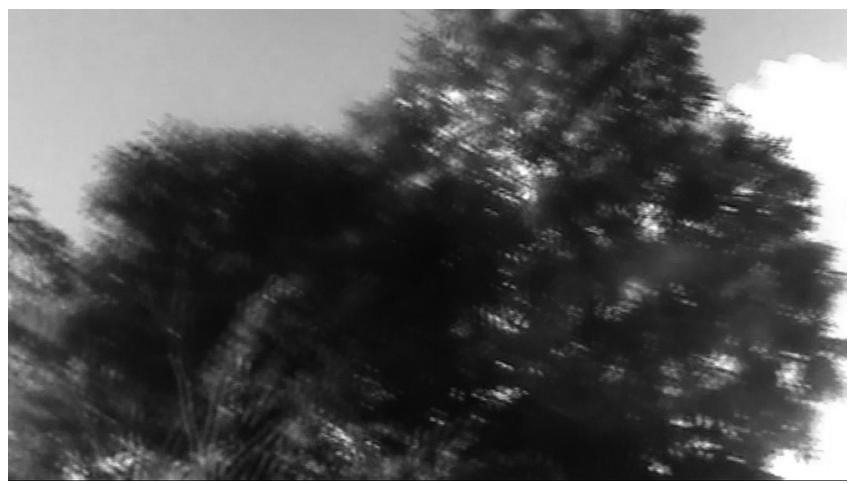

(Pré I, 2012, $3^{\circ}$ 20)

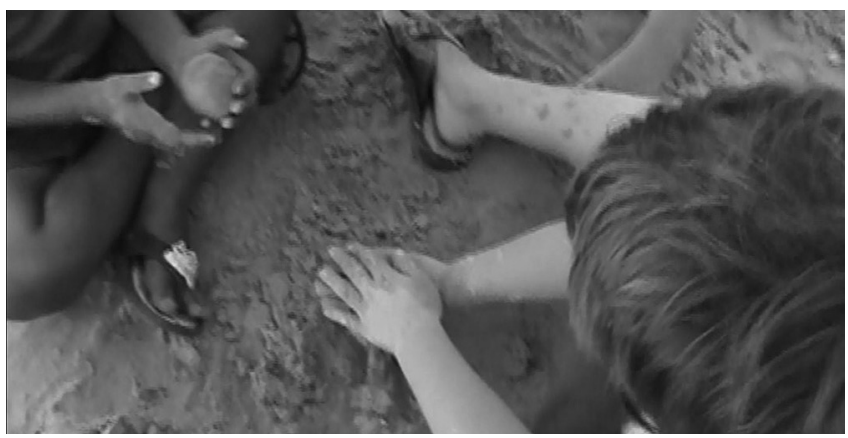

(Pré II, 2012, 2º)

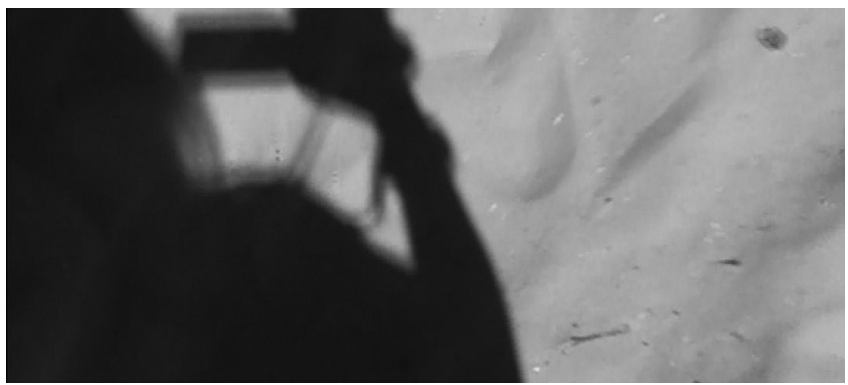

(Pré II, 2012, 128) 
INFÂNCIA, IMAGENS E VERTIGENS 51
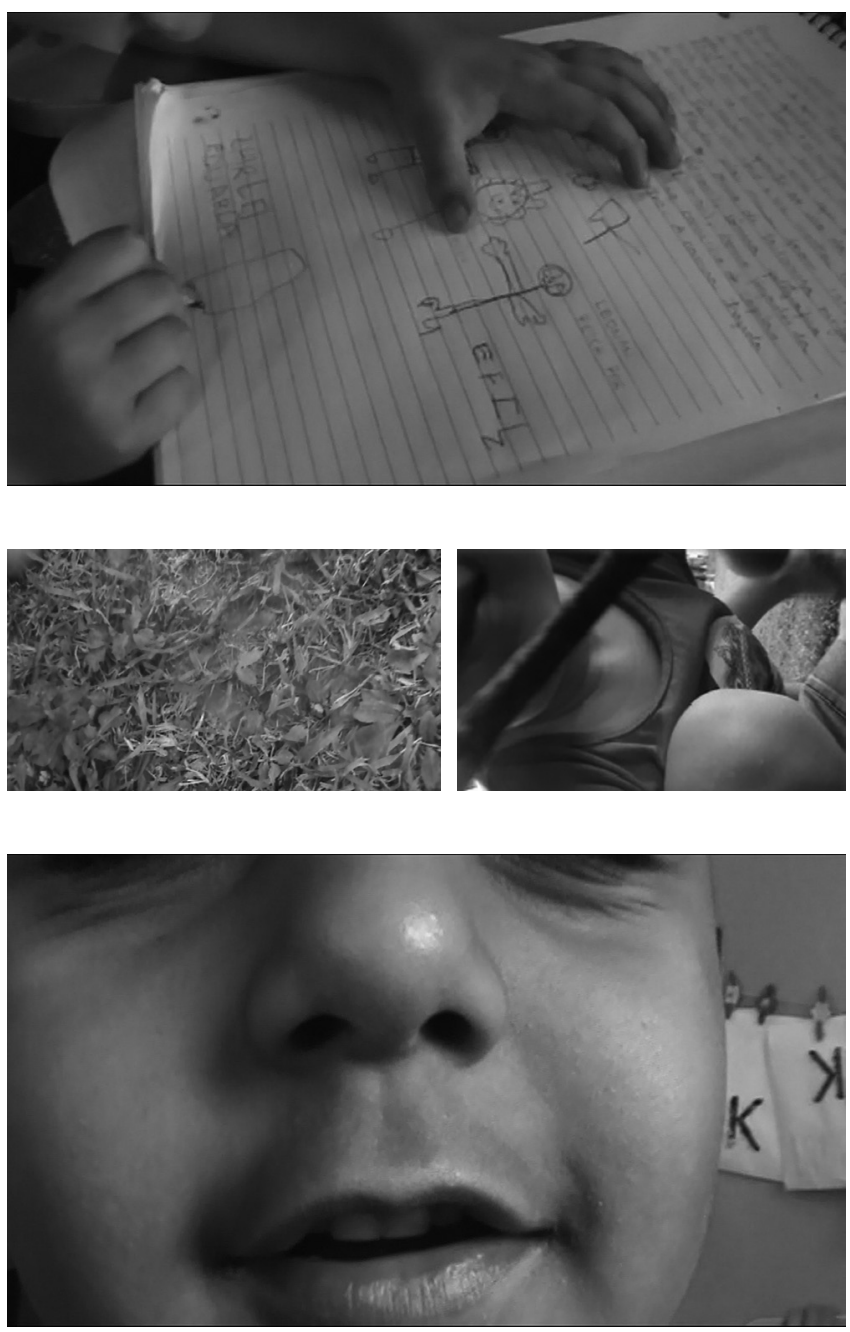

(Pré II, 2012) 
52 BIANCA SANTOS CHISTÉ
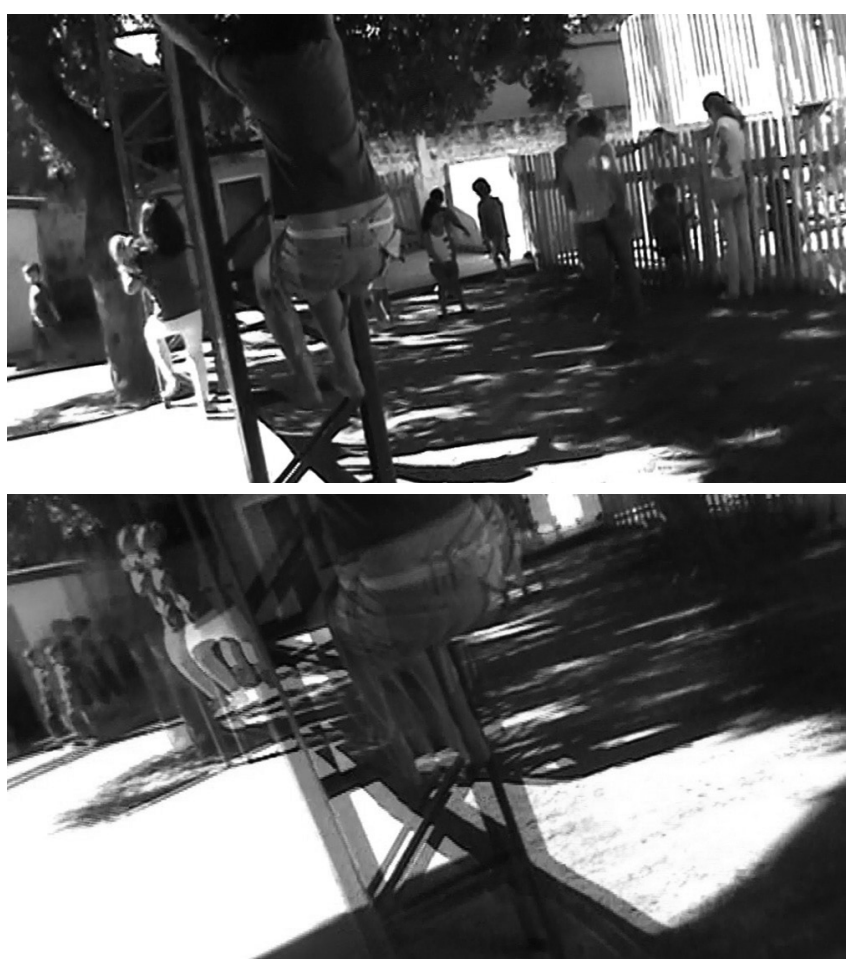

(Pré II, 2012, 2³) 


\section{2 \\ VESTíGIOS DE INFÂNCIA}

Nossa... Nossa senhora!!! É o céu!!!...

Agora pega o sol!

(Pré I, 2012, $3^{\circ} 18$ )

\section{Imagens da infância}

Depois que iniciei minha ascensão para a infância, Foi que vi como o adulto é sensato! [...]

Como não ascender ainda mais até na ausência da voz?

(Ausência da voz é infantia, como t, em latim) Pois como não ascender até a ausência da vozLá onde a gente pode ver o próprio feto do verboainda sem movimento. [...]

Como não voltar para onde a intenção está virgem? Por que não ascender de volta para o tartamudo!

(Manoel de Barros, 2013, p.380-1)

De maneira poética, Manoel de Barros apresenta o movimento de sua ascensão à infância, seu espanto frente à sensatez do homem adulto e seu desejo de distanciar-se 
do bom senso, do comportamento aceitável, do modo de pensar e agir modulado cada vez mais presente na sociedade atual. É na infância que Manoel busca, desde o próprio sentido da palavra - ausência de voz -, o momento pré-verbal da palavra, a experiência de experimentar o mundo sem necessidade de nomeá-lo, um des-ver, um des-velar o mundo, um des-falar o mundo. Não se trata de um retorno à infância, tida como ingênua, pura, onde ainda não há fala, um não falar, mas uma suspensão, como se suspendesse o fluxo narrativo, um gaguejar, tremer a voz, perder a fala diante do novo, espantar-se, assustar-se, surpreender-se, uma experimentação intensiva de si mesmo. Se colocar na infância do mundo, com um olhar inaugurador.

É desse lugar "privilegiado" de razão, de racionalidade, de sisudez, de rigorosidade, de modulação que foge Manoel de Barros, por isso, ele pergunta, mesmo já sabendo a resposta, e sabendo o que fazer, "Por que não ascender de volta para o tartamudo?” É lá, no tartamudo que ele, as crianças, a infância (e nós também) podem libertar-se das amarras impostas, da padronização, da colonização e da dominação adultícia, por meio do inesperado, do inusitado, do extraordinário.

Pensar a infância dessa maneira, com Manoel de Barros, parece ser uma possibilidade de afastar-se das ideias produzidas em torno da criança e da infância, distanciar-se de percepções, de ideias, de conceitos e imagens de tutelamento que produzimos em torno dela, invenção nossa, do adulto, uma invenção social (Schérer, 2009). Quando ouvimos ou lemos coisas sobre a criança e sobre a infância parece que as ideias produzidas em torno delas têm sido sempre no intuito de proteger, amparar e defender, na direção de torná-la um adulto. Em cada tempo houve (e ainda há) um conjunto de normas disciplinadoras que prescrevem o que é ser criança, como é o seu brincar, quais 
seus gostos, como pensa, o que deve saber, pensar e dizer em cada idade; e o que é ter infância. A criança e a infância são capturadas pelas ideias que produzimos sobre elas; criamos formas de aprisioná-las, parecendo que se pode antecipar tudo sobre elas, restando muito pouco para o inesperado e para os encontros.

Não paramos por meio dos dispositivos sociais de modular, de projetar sobre a criança e a infância os nossos medos, os nossos anseios e a perspectiva de um futuro sempre melhor. Elas são o material das utopias e dos sonhos políticos que visam o modelo de ser humano. Para isso, as crianças - a infância - precisam crescer logo, atingir rapidamente a maturidade adulta, a sensatez adulta, a prudência adulta, pois sem isso, será impossível, realizar o sonho de um determinado tipo de polis entendida como justa. Para isso precisamos normatizare moldar em todos os espaços, em todos os tempos, sempre com a intenção do que será melhor para a formação "de uma sociedade melhor". Como dispositivo Foucault (1985, p.244), diz que:

[...] é um conjunto decididamente heterogêneo que engloba discursos, instituições, organizações arquitetônicas, decisões regulamentares, leis, medidas administrativas, enunciados científicos, proposições filosóficas, morais, filantrópicas. Em suma, o dito e o não dito são os elementos do dispositivo. $\mathrm{O}$ dispositivo é a rede que se pode tecer entre estes elementos.

As relações estabelecidas a partir dos dispositivos podem vigiar, disciplinar, adestrar, controlar o corpo e o pensamento, além de criar e produzir modos de ser, de existir e de sentir. Elas ainda definem, nomeiam, prescrevem normalizações e condicionantes produzindo uma imagem idealizadora, programada da criança e da infância. Essas relações podem aniquilar toda possibilidade de 
experiência sensível, subtrair as sensações, as percepções, os afetos.

Nos espaços dos dispositivos comanda-se, ordena-se, controla-se saberes, organiza-se, calcula-se, mede-se, aperfeiçoa-se, estabelecem-se funções. Por meio desses dispositivos pode-se governar o mundo, os seres, as pessoas, adultos e crianças, governar então a infância. Então parece que a infância, para além de uma invenção social, ela é também, uma invenção política. A partir do momento em que a criança vai sendo descoberta, vai se tornando foco do olhar direcionado dos adultos (Ariès, 1981; Ghiraldelli Jr., 1997; Narodowski, 2001), vai se compreendendo suas especificidades, ela torna-se alvo de intervenção política e científica. A maneira adultocêntrica de pensar a infância, no qual a criança é vista como um ser em falta, um ser incompleto justifica a necessidade de intervir e governá-la.

Como governar a criança, a infância? Como torná-las úteis, servis, funcionais? Como podem "servir a sociedade"? Como nos diz Larrosa (2014, p.144) "[...] isso de "servir a sociedade" significa, para nosso governante, servir à indústria, ao comércio, ao turismo e, naturalmente, ao governo". Para isso, que ela sirva é necessário gerir sua vida, é necessária a produção de saberes sobre ela, assim obter-se-á um maior controle sobre seus desejos, suas vontades, suas paixões. Decide-se, determina-se então o que pode e não pode, o que deve e não deve ser dito, o que pode e não pode ser pensado delas e sobre elas. Aqui tanto a pedagogia, quanto a psicologia, na modernidade, talvez mais do que outras áreas do conhecimento, contribuíram na produção idealizadora do que é infância e ser criança: infância classificada em etapas, em processos de desenvolvimento linear, em condições determinadas, em limites conjecturados, em início e término definidos. São esses olhares, com suas maneiras de pensar a criança, 
a infância que produzem verdades sobre elas, que me parecem tomados por um discurso disseminado e autorizado. Ou como diz Carvalho (2014, p.2) "[...] infância coligida nas estratégias de governo, pois é preciso defender a infância, conceder a ela o que lhe é de direito, mas não tudo; educar a infância, tratar a infância, socializá-la, medicalizá-la, lançá-la nas estatísticas de governos, enfim, fazer a infância existir".

A nossa relação com a criança, com a infância tem sido de superioridade e inferioridade, no qual se separa o mundo em dois: do adulto e da criança. A linha divisória está indicada pelo próprio dualismo em que são idealizadas e que produzem ideias: enquanto a criança é um ser inexperiente, maleável, incapaz, inacabada, incompleta, de fácil convencimento, livre de responsabilidade, alegre, não civilizada, inocente, ingênua, um ser que nada pode no presente, a que segue evolutivamente em direção ao adulto, em etapas pré-estabelecidas. $\mathrm{O}$ adulto, em contrapartida, é o ser dotado de razão, de completude, experiente, responsável, civilizado, que tudo pode, que rege as leis e as normas a serem seguidas, que dita e molda o ser e a vida. $O$ adulto é aquele que dirige, domina, destrói com a intenção de perpetuar seus interesses e legitimar a superioridade de seus projetos.

Na mesma direção, a infância é pensada enquanto etapa ou fase da vida humana, diferenciada por estágios do desenvolvimento biológico, social e psíquico. Ainda pensada como a fase mais feliz da vida do ser humano, onde o brincar é universal e os problemas são inexistentes. A que corresponde a um período extremamente efêmero, vulnerável, uma fase sem importância e a que traz marcas a partir do pensamento platônico, como diz Kohan (2005, p.33-4):

[... ] a primeira marca que distinguimos no conceito platônico de infância é a possibilidade quase total, e enquanto 
tal, a ausência de uma marca específica, a infância pode ser quase tudo, esta é a marca do sem-marca, a presença de uma ausência; a segunda marca é a inferioridade, frente ao homem adulto, cidadão e sua consequente equiparação com outros grupos sociais, como mulheres, os ébrios, os anciões, os animais, esta é a marca do ser menos, do ser desvalorizado, hierarquicamente inferior; em uma terceira marca, ligada à anterior, a infância é a marca do não importante, o acessório, o supérfluo e o que pode ser prescindir, portanto o que merece ser excluído da polis, o que não tem nela lugar, o outro depreciado; finalmente a infância tem a marca instaurada pelo poder: ela é material de sonhos políticos, sobre a infância recai um discurso normativo, própria de uma política que necessita da infância para afirmar a perspectiva de um futuro melhor.

A criança e a infância são o que dizemos e o que determinamos delas e por elas, não se referem a unidades ou estruturas, mas escolhas sucessivas que fazemos. Distribuímos seus papéis, sua importância, sua utilidade e finalidade. Estabelecemos significado e sentido àquilo que dizem e fazem e tudo que não passa pelas ideias pré-formadas, é ignorado, excluído ou encontramos outros enquadramentos. Fixamos os ditos e não ditos, as verdades e os limites. Quando essas verdades são contestadas, se põem a tremer, são duvidadas, duvidosas, vaciladas, chama-se, como dizem Deleuze e Parnet (1998, p.106), "a terrível Luneta para cortar, o Laser, que repõe em ordem as formas, a criança e a infância em seu lugar". Estabelecemos o lugar da infância e da criança, criamos identidades fixas, territórios de representações, generalidades normalizadoras.

Nossa relação com a criança, com a infância foi sempre tuteladora. Procuramos capturar a criança, saber o que elas são (tentamos saber), compreendê-la, explicá-la, 
nomeá-la, acolhê-la, compreender seus gostos, o que pensam, por onde caminham. Direcionamos nosso olhar na maioria das vezes para o que as crianças pensam e fazem e com isso produzimos maneiras de subordiná-la, discipliná-la, docilizá-la, com intuito de intervir, de mudá-la, de moldá-la a nossa imagem e semelhança. Procuramos exercemos o poder sobre a vida dela, pois é um ser sem razão, impetuoso, desordeiro, insolente, áspero, irrequieto, indômito, como aponta Gagnebin (2005, p.168),

[...] a infância é um mal necessário, uma condição próxima do estado animalesco primitivo; que, como as crianças são seres privados de razão, elas devem ser corrigidas em suas tendências selvagens, irrefletidas, egoístas, que ameaçam a construção consensual da cidade humana graças à edificação racional, o que pressupõe o sacrifício das paixões imediatas.

Seria a criança, a infância monstros, ou mesmo demônios que queremos e precisamos domar ou aniquilar? Que ser é esse que nos apavora e nos amedronta? Que ser é esse acometido pela grave doença das paixões e dos desejos? Sufoquem os desejos! Retirem as paixões! Criemos espaços para controlar a impetuosidade com complexos dispositivos de controle, de confinamento e de reclusão extremamente disciplinadores. Formemos como diz Kohan (2005, p.99) “corpos dóceis e subjetividades conformes os mecanismos de controle que ela (a escola) contribui para disseminar". Tentemos produzir um único tipo de criança. Conhecemo-la para retirar toda sua força, toda sua potência.

Criemos técnicas bem definidas, bem planejadas para educá-la. Circunscrevemos todos os espaços, cerquemos todas as variáveis. Não devemos deixar brechas para o não pensando, para o inesperado, para a experiência, para o sensível. Aniquilemos as sensações, subtraíamos o corpo. 
O corpo, com suas sensações, engana, nos traí. Agenciemos seus desejos, suas vontades, seus afetos. Antecipemos suas ações, seus pensamentos, suas respostas, suas sensações, seus sentimentos. Controlemos. Definamos suas fases de evolução, de crescimento, de desenvolvimento. Digamos o que ela é, o que não é, o que pode ser e não ser. Convencemo-la que o que pensamos e fazemos é o certo, o verdadeiro, o melhor. Levamo-la a maioridade. Retiremos a infância da criança, e a criança da infância.

Da mesma maneira que ela é retirada da polis, ela é o lugar efetivo de exercício político. A educação vai modulando a sociedade, vai educando por meio de uma ideia, vai homogeneizando o pensamento, as ações, a maneira de se relacionar com o mundo. Parece que há um projeto de sociedade que modula a maneira de pensar, a maneira de agir, a maneira de sentir, modula até os caminhos que se deve seguir. Vai circunscrevendo os espaços, os tempos, os lugares, os seres, as coisas, o mundo. E tudo que não se enquadra, não se encaixa, vai sendo deixado fora, para fora, como fazemos com as crianças, com a infância. Mas, me parece, nesse caso, que ficar de fora, ficar para fora pode ser bom, pode ser um não-lugar revelador de possibilidades, um espaço de sobrevivência. Por isso, um espaço de transgressão, de criatividade, de experiência, inventividade, por isso infância.

Parece que o tutelamento sempre esteve presente nas relações entre adulto e criança. Quando fazemos isso perdemos a criança, pois ela é vista, na maioria das vezes, com o olhar de adulto, um olhar de prescrição, e isso nos separa da criança, nos distancia dela. Às vezes ainda, chego a pensar que as crianças são inalcançáveis, pois quanto mais procuramos capturá-la, mais elas nos escapam, pois são compostas de multiplicidades, intensidades e velocidades que se arrastam para outros tempos e espaços distanciando-se do processo de subjetivação do 
poder sobre a vida. É possível olhar para criança sem um olhar tutelador e prescritivo? É possível encará-las sem os significados e o imperativo de sentidos dados? É possível relacionar-se com elas sem a obsessão de inteligibilidade?

Muitos têm sido os modos de pesquisar a infância, a criança e a educação. Muitos também são os desafios que se colocam quando se pesquisa com crianças. Muitas são as maneiras de compor as ideias em torno da infância, da criança e da educação. Assim, pensar com as imagens produzidas pelas crianças, com a infância, com a criança pode ser uma tentativa de pensar uma educação distanciada dos modelos, distante das modulações pedagogizada e psicologizada que tem habitado o universo infantil, bem como, distante ainda, da ditadura do corpo, do sentido, do tempo.

Como seria pensar a criança e a infância distanciada dos estereótipos que temos produzido nossa imagem de criança e de infância? Como seria pensar a partir de uma relação de diferença e não de superioridade e inferioridade? Então o que ainda dizer nessa composição? Como traduzir palavras que me parecem não serem feitas de palavras? Haveria outra maneira, outros meios, ou mesmo outras línguas que nos ajudasse a falar sobre a infância e sobre a criança? E se para dizer o intraduzível fosse preciso dizer com ele? E se em lugar de falar sobre a criança e a infância, da criança e da infância, pela criança e pela infância, tentasse pensar e dizer com elas? O que dizer de alguém ou algo que não representa (a representação está no lugar de algo), ou dizendo de outra maneira o que dizer distanciando-se da imagem idealizada que fazemos? Ou o que dizer sem criar uma imagem idealizada? Tarefa difícil essa!

E olha que eu passei daquele perfume hein! Eu passo bastante. Eu gosto de exagerar. 
Isabella se você exagerar vai ficar muito forte e vai arder.

Eu sei, mas eu gosto.

Não, vai acabar mais rápido!

(Pré II, 2012, 15²1)

E se em vez de dizer algo delas, disséssemos o que nos toca quando somos atravessados pela infância, pela infância do mundo, das crianças? E se as produções imagéticas das crianças nos provocassem, até nos convidassem a pensar coisas outras? Acho que é assim que quero me colocar nessa escritura. Dizer coisas que nasce desse encontro.

O primeiro deles me faz pensar que com infância, com crianças, podemos sair dos limites territoriais, nos deslocarmos das instâncias personificadas, escapar às modulações do modo de ser e de existir, pensar sem enraizamento, deslizar vertiginosamente entre as ordens, entre atos, sair dos dualismos, experimentar a vida, inventar modos de ser e existir, estabelecer zonas de vizinhança com o mundo, com os seres, com as coisas, involuir inventivamente.

As Nações já tinham casa, máquina de fazer pano, de fazer enxada, fuzil etc.

Foi uma criançada mexeu na tampa do vento

Isso que destelhou as Nações. (Barros, 2013, p.173)

Outro convite a pensar que, somos seres de desejo. Desejar não como propriedade, como posse ou algo que se possa se erguer e dizer "eu desejo isso" ou se apossa. Muito menos desejar a partir da falta, da castração, da ausência de algo. Desejar sem capturar, sem aprisionar, sem se apossar. Desejar sem meta, nem fim, nem continuação infinita. Desejar como delirar, delira-se sobre o mundo, as coisas, os seres. O desejo pode ser revolucionário, de expedição de exploração, de experimentação, passante, movente. $\mathrm{O}$ 
desejo faz fluir, cortar, correr, deslizar. O desejo é sentido, pode fazer algo, produzir efeito, conexões, disjunções, circuitos e curto circuito.

Um desejo. Um acaso. Um achado. Uma descoberta. Uma surpresa. Uma incerteza errante, rápida. Um sem desejo, sem deter-se. Uns cem desejos. Cem. Uma vida imersa no desejo, desejante, desejado, desejável? Ou um desejo imerso em uma vida, viçosa, virada, diva? Uma vida desejante, desejada. Que nada. Desviante, viajante, sentida, atravessante, tocante. Desejo inventado, não dado, de fato, desatado, desprendido, que pode produzir práticas de liberdade.

Eu vou procurar lá em casa um barbante pra você tirar seu dente, tá bom...

Arranca o dente logo ai...

Ranquei, ranquei!!!

Deixa eu ver, ah, ah, ah!!!

Arrancou Emilly?

Arrancou!

Viu já tava caindo!

Agora guarda ele pra levar pra mamãe.

Depois coloca debaixo do travesseiro.

É que a fadinha do dente, a fadinha do dente vai vir.

E pega seu dente e troca por dois reais.

Eu sei quem é a fadinha do dente, é a mamãe do dente.

Eu já descobri quem colocou dentro da capa do meu travesseiro um dia, foi minha mãe.

É a fadinha do dente!

Um desejo perigoso, pois os agenciadores do desejo não poderão controlá-lo, eliminá-lo, subtraí-lo. Desejo que nos amedronta, nos apavora. Em nome de uma sociedade determinada como melhor, agenciamos os desejos, os desejos das crianças. Agenciam nossos desejos. 
Desejo, delirante que faz soar sinos de alegria? Deleuze e Guattari (1996, p.15) nos diz, "acontece que existe uma alegria imanente ao desejo, como se ele se preenchesse de si mesmo e de suas contemplações [...]”. As crianças soam, vibram, tremem, retumbam, ecoam, festejam, bradam, ressoam, ecoam, alastram, contagiam, contaminam, gracejam, gargalham. Há uma alegria que cheira à vida, diante do novo, do olhar que inaugura o mundo. Que resiste à morte, ao peso, à servidão. Exercício de destruição de desformalização. Alegria tira a forma, tira da forma, desforma, reforma, ri da forma. É só vida, corpo gritando, rugindo, bramindo, brandindo, transformado, transformando. Resistência de vida. Invenção constante da vida. "Experimenta alegrias! regozija-se então e pensa em continuar a regozijar-se frequentemente; e para isso deve pensar" (Nietzsche, 2011, p.35).

Alegria dispara o riso que contagia. "O riso destrói as certezas”, nos diz Larrosa (2010, p.181) É de um, de mais um, mais um... Nãoé de um, nem de mais um, nem todos. Nem relação de dois. E nem de um a outro. É o que passa por nós, entre nós. Que se compõem com em vizinhanças. Dupla captura. Fluxos que se conjugam, carregando, arrastando todos a conquistar o mundo. As crianças conquistam o céu, conquistam o chão, conquistam o sol, conquistam a cor como o pintor, entram no céu, no chão, no sol, na cor. É ali que a alegria pode estar localizada. Há intimidade na conquista, quase uma simbiose.

Alegria atravessada pelo sensível... Parece que com crianças há um exercício do sensível. Elas são seres do sensível. Parece que o mundo, os seres, as coisas lhe atravessam como flechas, não passam entrem elas sem serem sentidas, tocadas de alguma maneira. Elas transbordam as forças daqueles que são atravessados por elas. São atravessadas por um conjunto de percepções e sensações que vão além delas. Esse olhar sensível não vem dos olhos, da pele, 
tocada, vista, recordada, mas das intensidades contínuas que o compõem. Seria como a criança, ser do sensível percorresse, como nos diz Deleuze e Guattari (1995, p.32) "uma região contínua de intensidades, vibrando sobre ela mesma, e que se desenvolve evitando toda orientação sobre um ponto culminante ou em direção a uma finalidade exterior".

O sensível existe apenas pelo fora e no fora. Entre. No meio. No Instante. Por Distanciamento. Aproximação. Distancia indecomponível. Composição. Decomposição. Torna-se tornando. Deslocando. Multiplicidade em movimento. Deslizando entre as coisas, os seres, o mundo ainda em gestação. Entrar em estado de árvore, como diz Barros (2013, p.464) "para sentir os enleios dos cantos. E enxergar os perfumes do sol”. Não falar da coisa, tocar a coisa, mas torna-ser a coisa em seu estado mesmo. Fazer nascer novas explosões, vibrações, sabores, modos de existência. Fazer comunhão, como as crianças de "um orvalho e sua aranha, de uma tarde e suas garças, de um pássaro e sua árvore”. (Barros, 2010, p.30)

Nossa, nossa senhora! É o céu!

Deixa eu vê!

Vem cá vê!

É o céu!!! Hahaha!

Faz assim! Hahaha!

O céu! Hahaha!

Hahahahahaha! Que massa!

Filma o céu! Filma lá! Hahahahaha!

Dindindindidin!

Haaaaaaaaaa!

Ta parecendo que nós tamo no céu! Hahahahaha!

É, cacacacacá!

Tamo até nas nuvens! Haaaaaaaaa! (Pré I, 2012, 13² 8) 
As crianças modificam o mundo, os seres, as coisas e são modificadas por eles no jogo de forças que desenrola entre elas e os outros corpos do mundo. Movimento infinito de composição de forças, que faz emergir modos singulares de ser e de existir. Força que sacode e desenraiza o verbo ser. Por isso, dizem Deleuze e Parnet (1998, p.05) "através de cada combinação frágil é uma potência de vida que se afirma, com uma força, uma obstinação, uma perseverança ímpar no ser". Fazem a vida vibrar e se inventar. É a força dos encontros com a vida que transborda delas e nos alcança. Como o mundo as toca de maneira violenta elas relacionam-se com os seres, as coisas, o mundo de maneira intempestiva, inesperada, potente.

As crianças são conjuntos de forças, de potências devindo. Não param de entrar em paixões, em aventuras, nas cores, em nascimentos. Não se compõem em permanências, mas arrastam suas expedições para outros lugares. Caminham sem sair do lugar, percorrem terras sem mover-se, anulam fim e começo, abalam e destroem os modelos, não começam nem terminam. Estremecem e afetam o céu, a terra, a água, o fogo e até mesmo o som. Força de bagunçar o mundo em seu entorno. Arremesso de rochas. Pilhas de fumaças. Ondas de tempestade. Olhos de ciclone. Vulcões em erupção.

A invenção política da infância opera em reduzir os desejos, a alegria, o sensível, a nossa potência de vida. Porque ela atua de todos os lados. Oprime as crianças e as pessoas que convivem com ela. Instaura-se, adulto e criança, em um tempo - o cronológico - linear, sucessivo, mensurável, e não um tempo em nós. Em nome de uma suposta ordem, de uma criança, de um adulto, de um professor ideal e personificado, modulam-se vidas, homogeneízam-se pensamentos, expropriam-se sentimentos e experiência sensível. Ensinam-se, com diz Fernandes (1997) a frear as paixões, a controlar a si mesmo. 
Há uma tentativa em andamento para livrar a infância de sua incômoda espessura, uma tentativa de apagar da infância todo sabor e toda ressonância, a tentativa de impor pela violência uma infância lisa, sem manchas, sem sombras, sem corpo, uma infância dos desinfantes, uma infância sem outro no qual ninguém escuta a si mesmo quando fala, uma infância despovoada. ${ }^{1}$

\section{Devindo, devém, devir}

Naquele dia eu estava um rio.

O próprio.

Achei em minhas areias em minha concha.

A concha trazia clamores do rio.

Mas o que eu queria mesmo era de me aperfeiçoar quanto um rio.

Queria que os passarinhos do lugar escolhessem minhas margens para pousar.

E escolhessem minhas árvores para cantar.

Eu queria aprender a harmonia dos gorjeios.

(Barros, 2013, p.432)

A poesia em epígrafe, de Manoel de Barros, poeta que brinca com a desordem, produz desordem com das palavras, dos sentidos, das coisas. Inventa mundos, que descortina o olhar cristalizado das coisas, que atua em outra temporalidade, não cessa de afirmar devires: devir-rio, devir-árvore, devir-criança; outros e inumeráveis devires. Nessa epígrafe, Manoel de Barros não se parece com um rio, não se assemelha a um rio, nem equivale a um rio, nem imita um rio, nem se identifica com um rio, pelo contrário, ele é o próprio rio, "Naquele dia eu estava

1 Este texto foi adaptado do texto fragmento de texto de José Lins Prado (in Larrosa, 2014, p.60). 
um rio. O próprio”. Devir-rio, devir, devires é uma construção do presente, do tempo de agora, do tempo agora, do já, já.

Um devir não é marcado pela sucessão do passado, do presente e do futuro planejado e previsível; não se confunde com o passado e futuro das coisas, o que interessa a um devir é o presente, é o presente da transformação, da mudança. Devir não se relaciona a um curso histórico, linear, cronológico, não se materializa considerando o passado e o futuro, nem como uma passagem de uma forma a outra, mas sim, como movimento que confronta as formas. Um devir é processo que nos arrasta do ser.

Devir se afirma na invenção, na criação, ele se afirma na criação, por isso ele é revolucionário, não tem modelo, não segue modelo, nem se origina de, não tem origem, não tem ponto de saída e muito menos de chegada. É um caminhar tateante, sem rumo. Entretanto, nos leva, nos arrasta, nos desloca para outros lugares, nos tira do chão, nos tira o chão. Uma linha de devir não demarca território, nem circunscreve, mas desterritorializa. Ele está sempre no meio, entre dois, na fronteira, pois devir se faz pela fuga das formas, dos modelos, através de alianças, por isso ele produz uma zona de vizinhança, ou de indiferenciação de tal modo que se torna difícil distinguir os devires.

No fragmento do poema de Manoel de Barros, "Queria que os passarinhos do lugar escolhessem minhas margens para pousar. E escolhessem minhas árvores para cantar" percebemos a presença de diferentes devires, de maneira que é impossível distinguir onde começa e termina o eumenino Manoel, um devir-árvore, um devir-rio. Aqui o corpo "eu" não imita um rio, não imita uma árvore, nem se assemelha a eles, e muito menos um jogo de palavras, mas, é o próprio rio, a própria árvore. Já não há "eu” menino-Manoel, nem rio, nem árvore, sendo que, um desterritorializa o outro, "numa conjunção de fluxos, num 
continuum reversível de intensidade" (Deleuze; Guattari, 2003, p.48).

Devir tem mais a ver com as linhas que nos atravessam, com os afetos, com a maneira que somos afetados e produzimos afetos, com os encontros, com os acontecimentos. "Devir é, a partir das formas que se tem, do sujeito que se é, dos órgãos que se possui ou das funções que se preenche, extrair partículas, entre as quais instauramos relações de movimento e repouso, de velocidade e lentidão, as mais próximas daquilo que estamos em vias de nos tornarmos, e através das quais nos tornamos" (Deleuze; Guattari, 1997, p.18). Os devires tem a ver com minorias, são minoritários, pois eles se localizam do lado de fora, às margens, na beira, nas bordas, na periferia, por isso, não se conformam a modelos, não tem modelos, deformam a realidade dada, inventam novas forças.

O sentido de menor, de minoritário nada tem a ver com condição inferior ou de desvalorização, pelo contrário, o sentido de menor, de minoritário, de minoria aqui é potência de criação, pois se constitui como algo que está sempre se fazendo, em processo. Pensar que um devir tem a ver com o minoritário, com menor, com minoria, significa compreendê-lo como aquele que está abaixo da palavra de ordem e que se localiza fora do comum, do esperado, do imposto pela maioria, por isso, por não ser a maioria. Por não ser o hegemônico, o homogêneo, o estabelecido, o dado, o dogma, desafia a imposição, pode devir, pode criar, pode recriar, pode inventar, ou seja, ele como potência de criação se contrapõe a um definido, estabelecido, determinado, que já não pode inventar.

Um devir, devires se instauram em uma outra temporalidade, em outro tempo que está posto na vida humana e cotidiana, habitam outro tempo diferente do tempo sucessivo, cronometrado, sequenciado, delimitado, controlado, imperioso, tempo Cronos. O tempo posto numa sucessiva 
somatória do passado, do presente, do futuro que instaura a história na sucessão de fatos e acontecimentos. O tempo maior que regula e delimita nossas vidas numa série de movimentos numerados, pré-estabelecidos, sendo que, qualquer fuga a esse tempo caracteriza-se como perda de tempo. Podemos observar isso quando Alice está no País das Maravilhas (Carroll, 2002, p.94-96), em uma de suas conversas com o Chapeleiro ela o recrimina por perder tempo com charadas e lhe diz "Acho que você poderia aproveitar melhor o seu tempo, em vez de desperdiçá-lo propondo charadas que não tem resposta". Ou ainda quando a rainha berra ao Chapeleiro "Ele está matando o tempo! Cortem a cabeça dele!"

Entretanto, o tempo que habita um devir, é um tempo que indica a intensidade da vida humana, uma duração desmedida, não numerável, não sucessiva, mas muito intenso, muito potente, o tempo aiônico. Um tempo criança, como nos diz Kohan (2007, p.86-87) “aión é uma criança que brinca (literalmente criançando), seu reino é de uma criança) [...]. No reino infantil, que é o tempo, não há sucessão, nem consecutividade, mas intensidade da duração". Na obra de Carroll (2002, p.95), entre uma conversa e outra, o Chapeleiro provoca Alice ao falar do tempo. Enquanto a pequena preocupa-se com o tempo e o aproveitamento do mesmo, o Chapeleiro propõe uma subversão do tempo fixo do calendário, do tempo conhecido, ao sugerir uma brincadeira com o tempo ao suspendê-lo, ao pará-lo temporariamente, "Você só teria que sussurrar uma dica para o Tempo, e o ponteiro giraria num piscar de olhos! Uma e meia, hora do almoço! [...] você poderia manter o relógio marcado por quanto tempo quisesse". O que está em jogo no tempo que consiste o devir é a intensidade da duração do vivido, do experienciado, do acontecimento, da experiência. Seria como se pudéssemos suspender o tempo cronológico colocando reticências ao 
final da frase, como fez Manoel de Barros (2013) ao interromper o voo de um pássaro pondo ponto no final da frase.

Algo parecido acontece no País dos Brinquedos, do romance de Collodi (2002), em que Pinóquio a convite de seu amigo Lucignolo aventura-se por esse país. Ele, o amigo, explica que no País dos Brinquedos o calendário, o tempo é posto de outra forma, ou seja, cada semana é composta de seis sextas-feiras e um domingo e as férias de outono começam no primeiro dia de janeiro e termina no último dia de dezembro, há aqui uma subversão do tempo, uma paralisação e destruição do calendário. Muda-se a noção do tempo com a entrada do jogo, da brincadeira na vida cotidiana. De acordo com Agamben (2005) tudo o que existe no País dos Brinquedos é o jogo, a brincadeira, no qual a vida cotidiana é invadida por eles. Em consequência dessa invasão há uma mudança e uma aceleração do tempo. Segundo Agamben (2005, p.85) “[...] O país dos brinquedos é um país que os habitantes se dedicam a celebrar ritos e a manipular objetos e palavras sagradas, das quais, porém esqueceram o sentido e o escopo", na qual as horas correm como relâmpago e não há alteração nos dias.

Você já viu baleia no rio?

Eu já!

Baleia no rio?

No rio já.

No mar!

Também!

No mar que existe baleias.

Então, lá no rio também!

Existe baleia no mar!

Não!

Existe sim! (Pré II, 2012, 15²15) 
Desse modo, pensar um devir, o tempo, a temporalidade pode ajudar a pensar a infância. Podemos pensar a infância de duas maneiras: uma que segue o tempo da progressão sequencial, funcional e das etapas cronológica do desenvolvimento e que se educa de acordo com um modelo pré-estabelecido. E a outra como devir potencial e criativo, como experiência, acontecimento, resistência, revolução. Essa infância é também intensidade, movimento, inesperada, intensa, deslocamento, potência, possibilidade real. É aquela que rompe, interrompe a história, é a própria descontinuidade da história. Assim, pensar a infância sob esse olhar é um convite a pensar no devir-criança, como destacam Deleuze e Parnet (1998), no qual devir é um movimento pelo qual as coisas escapam da mesmice, do habitual e se transformam, criando brechas, fissuras, fendas para que isso aconteça.

Que dia você nasceu?

26 de dezembro.

Você também né Júlia?

Aham!! No mesmo dia na mesma hora, no mesmo hospital.

A gente é irmã! (Pré II, 2012, 15²15)

Devir é uma experiência que rompe com as imposições, com as estratificações e com as separações. Devir é deslocamento, é sair do lugar, é movimentar-se, é sair para fora, é sair fora, é expor-se. Ele se impõe ao modelo e às formas dominantes do ser humano, do ser humano dominante, por isso, ele é revolucionário, criador, é força em potência, é a própria potência. Para Schérer (2009, p.205) o devir criança inicia-se "com a ideia de escapar da família, de casa. De sair do apartamento. E por essa atitude, ela se define imediatamente contra os estágios de desenvolvimento, a fixação, a territorialização sobre instância personificadas do pèrémère". 
Devir-criança não caracteriza um retorno a uma infância que seria inocência ou mesmo infantilizada, mas ao contrário, dispara e produz aberturas, é ainda, resistência, escapada, fuga, libertação da condição imposta ou pré-estabelecida pelo mundo adulto. Ou ainda como destaca Kohan (2007, p.93) "Devir- criança é, assim, uma força que extrai, da idade que se tem, do corpo que seé, os fluxos e as partículas que dão lugar a uma "involução criadora", a "núpcias antinatureza”, a uma força que não se espera, que irrompe, sem ser convidada ou antecipada". Assim, devir, devir-criança, é pois possibilidade de mudança, é força da criação do novo, do inusitado, do inesperado, é um caminhar tateante, sem rumo, sem destino, é expressão de vida, vida acontecimento, vida em movimento, vida em experiência, vida experiência, ou ainda a própria condição de ser afetado, pois caracteriza-se permanentemente como transformação.

Mais uma vez Deleuze e Guattari (1997), Gagnebin (2005), Agamben (2005), Kohan (2007) e Leite (2011) nos ajudam a pensar nos modos dominantes de pensar a infância já consolidados em nossa cultura ocidental. Busco nesses autores modos de pensar a infância, a partir da lógica da presença e não da ausência, marca essa que constitui um pensamento, uma ideia da infância que tem sido fundadora em nossa tradição. $\mathrm{Na}$ direção, de pensar com os autores acima citados, a infância como um outro lugar, lugar-outro diferente do que se tem posto em nossa cultura, laica ou acadêmica, necessário se faz deslocar o olhar onde a criança é vista como ser que será, um ser do futuro, olhar da instrução e das questões próprias da educação, para olhá-la, ou melhor olhar as crianças, as infâncias desde elas mesmas, desnudadas do olhar daquele que deve ser formado pelo adulto.

Nesse sentido, Kohan (2007, p.101) faz um convite para pensarmos "a infância a partir do que ela tem e não do 
que lhe falta: como presença, e não como ausência; como afirmação, e não como negação; como força, e não como incapacidade". Podemos então pensar a infância para além da identidade pré-estabelecida, delimitada, circunscrita e psicologizada por uma série de enunciados que definem o que ela é, e não é, e o que ela pode ou não pode fazer. Há aqui uma ideia de infância que atravessa a ideia de etapa da vida - a infância como condição da existência humana. Kohan (2005, p.246), continua:

[...] a infância reveste uma outra posição. Ela deixa de estar associada a debilidade, precariedade, inferioridade. Ela já não mais é medida pela categoria de progresso, numa temporalidade contínua; ela é descontinuidade, irrupção do pensamento, do possível, do porvir. [...] Por um lado, ela deixa de estar necessariamente associada a crianças, e sua visão concomitante com seres humanos pequenos, frágeis, tímidos. Por outro lado, ela passa a ser condição de rupturas, experiência de transformações e sentido das metamorfoses de qualquer ser humano, sem se importar sua idade.

A criança, a infância tem a ver com a possibilidade de instaurar e intensificar uma certa relação com o tempo, com o espaço, com o corpo, com o mundo e com várias outras coisas. Há um novo mundo porque há infância. "A criança, a infância é o reino do como se, do faz de conta, do se as coisas fossem de outro modo. É o acontecimento que impede a repetição do mesmo". Em muitos de seus poemas Manoel de Barros apresenta poeticamente a forma como a criança descobre o mundo de uma maneira inventiva, criadora e curiosa como ressaltado no poema abaixo:

O menino caiu dentro do rio, tibum,

Ficou todo molhado de peixe...

A água dava rasinha de meu pé. 


\section{$[\ldots]$}

Você viu um passarinho abrido naquela casa

que ele veio comer na minha mão?

Minha boca estava seca igual do que

uma pedra em cima do rio (Barros, 2013, s/p).

Assim, as crianças, como Manoel de Barros, brincam com a seriedade e o bom senso das coisas, dos sentidos. Animam pedras, sucatas, objetos, sentimentos e pensamentos. Criam palavras, geram ideias, inauguram novos e outros sentidos e expressões. Mudam os significados de lugar, subvertem limites, rompem com o pensamento ordenado e linear da lógica estabelecida, profanam e dessacralizam o sagrado. Espantam-se, admiram-se, afetam-se, e são afetadas. Buscam sentidos sem a preocupação em ensiná-los ou aprendê-los. Constituem devires: devir-pai, devir-mãe, devir-bicho, devir-chão, devir-árvore, esses e outros devires. Não fazem como ou imitam, mas torna-se tudo isso para inventar novas forças, novas armas, para fugir das imposições, da homogeneidade, ou seja, os devires impede-os de serem homogêneas. Para Deleuze (1997, p.88): "As crianças se exprimem assim, um pai, um corpo, um cavalo. [...] $\mathrm{O}$ artigo indefinido não carece de nada, sobretudo de determinação. Ele é a determinação do devir, sua potência, a potência de um impessoal”.

Assim, a criança não imita o pai, a mãe, o cavalo, o bicho, o mundo, assim, como não se imita este ou aquele pai, esta ou aquela mãe, mas torna-se pai, mãe, bicho, folha, como diz Deleuze (1997, p.88) "atingindo uma zona de vizinhança em que já não podemos distinguirmos" aquilo que ela se torna. Ela os inventa, colocando em movimento outras composições que acentuam a potência da vida. Ou poderia dizer ainda, é pela infância, como abertura, como acontecimento, como lugar na dobra, no intermezzo, que ela faz surgir outros modos de vida. 
To tentando procurar a nuve...

A nuve, a nuve tá ficando preta, a preta tá misturando coma branca, quer dizer que vai chover!

Vai chover agora?

Se protejam da chuva.... vai chove, vai chove! (Pré I, 2012)

Ao pensar em criança, em infância, que o brinquedo, a brincadeira é uma maneira em que esses devires se manifestam. O brincar possibilita à criança criar, imaginar, pensar, inventar, transgredir, dialogando entre os pares e com ela mesma. Para Benjamin, (2002, p.94) brincar "significa sempre libertação", além disso, nesses momentos ela é livre para determinar suas próprias ações. $\mathrm{Ou}$ seja, é no contexto da brincadeira e no brinquedo que ela determina, escolhe, fala, ouve, posiciona-se, rompe com a fixação das regras e das normas. "Os seus brinquedos [...] são um mudo diálogo de sinais entre a criança e o povo”. (Benjamin, 2002, p.94)

Mais uma vez o romance Pinóquio, de Collodi (2002), pode ajudar a pensar sobre a brincadeira como possibilidade de rompimento com o tempo, com os objetos, com as ordenanças, com os ritos e com tudo que com o tempo sacraliza-se. No País dos Brinquedos, país que não se assemelha a nenhum país do mundo, o boneco de madeira, seu amigo e mais uma centena de meninos, fogem do mundo das ordens impostas, das regras, das limitações, da castração e da ausência de liberdade. Nesse país, por meio do jogo e da brincadeira, com uma população composta somente por crianças, há destruição da ritualização, da transgressão do inviolável, do santificado, pois nesse lugar as crianças podem brincar e gritar de manhã à noite, não há controle do tempo, nem do que fazer, não há órgãos, nem pessoas reguladoras das ações e dos pensamentos. 
Você já viu baleia no rio?

Eu já!

Baleia no rio?

No rio já.

No mar!

Também!

No mar que existe baleias.

Então, lá no rio também!

Existe baleia no mar!

Não!

Existe sim! (Pré II, 2012, 15²15)

Elas, as crianças transgridem tudo, incluindo a linguagem padronizada: escrevem com carvão coisas como Vamo brincá, em vez de Vamos Brincar. Isso indica que as crianças, por meio da brincadeira e do brinquedo, transformam, transgridem, dessacralizam, ou como diz Agamben (2007), profanam, todo ou qualquer objeto que estiver a seu alcance. Por meio da profanação as crianças deformam o uso comum das coisas, tocando no sagrado para libertá-lo, fazendo, criando, inventando assim, um novo uso. A brincadeira, o brinquedo, ainda as faz enfrentar e a lidar com toda a disciplinação e restrição imposta pelo outro, pelo adulto, pelo mundo adulto.

Se não houvesse criança, se não houvesse infância não haveria possibilidade de continuidade nossa com o mundo, seríamos um corpo sem movimento, sem mobilidade, completamente inertes, ou como declara Larrosa (2010, p.187), “[...] o nascimento põe a criança em continuidade conosco e com o mundo”. É porque a humanidade tem infância, que ela tem história, a infância seria então a condição da história e da experiência do ser humano. A etimologia latina da palavra in-fância, não revela a (in) capacidade da criança em falar, a (in) completude infantil, mas nos mostra que essa ausência de voz, 
in-fância é uma condição do ser humano, pois, nos constituímos como sujeitos na e pela linguagem. O único animal que aprende a falar é o ser humano, e não o faria se não houvesse infância; é por meio dela que é introduzido na natureza do homem "a descontinuidade e a diferença entre língua e discurso” (Agamben, 2005, p.64). É pela infância que se promove a possibilidade de continuidade com o mundo, ou como coloca Arendt (2009, p.247) é "pelo nascimento que esse mundo constantemente se renova", pois sem infância, sem a abertura do novo, do imprevisto, do inesperado o mundo seria uma inevitável ruína.

A infância, como a arte, não existe para ser útil, ela existe porque "é condição da história e da experiência, sem infância o ser humano seria natureza inerte. A infância, de contínuo nascer, ela é a possibilidade de quebrar essa inércia repetitiva do mesmo que seduz a um mundo sem nascimento" (Kohan, 2005, p.252). Quiçá a infância, as crianças, as infâncias-crianças possam mostrar ao mundo, como esperança Leite (2011) - pela sua pequenez e pela sua incapacidade, anunciada no próprio prefixo in da palavra - o seu lugar, como um lugar da possibilidade daquilo que é, e não só do que pode vir a ser. Ou poderia ainda dizer, quem sabe o mundo possa enxergar a criança, a infância como ser humano potente, criador, inventivo, renovador, como ser que é, como potência de vida. 

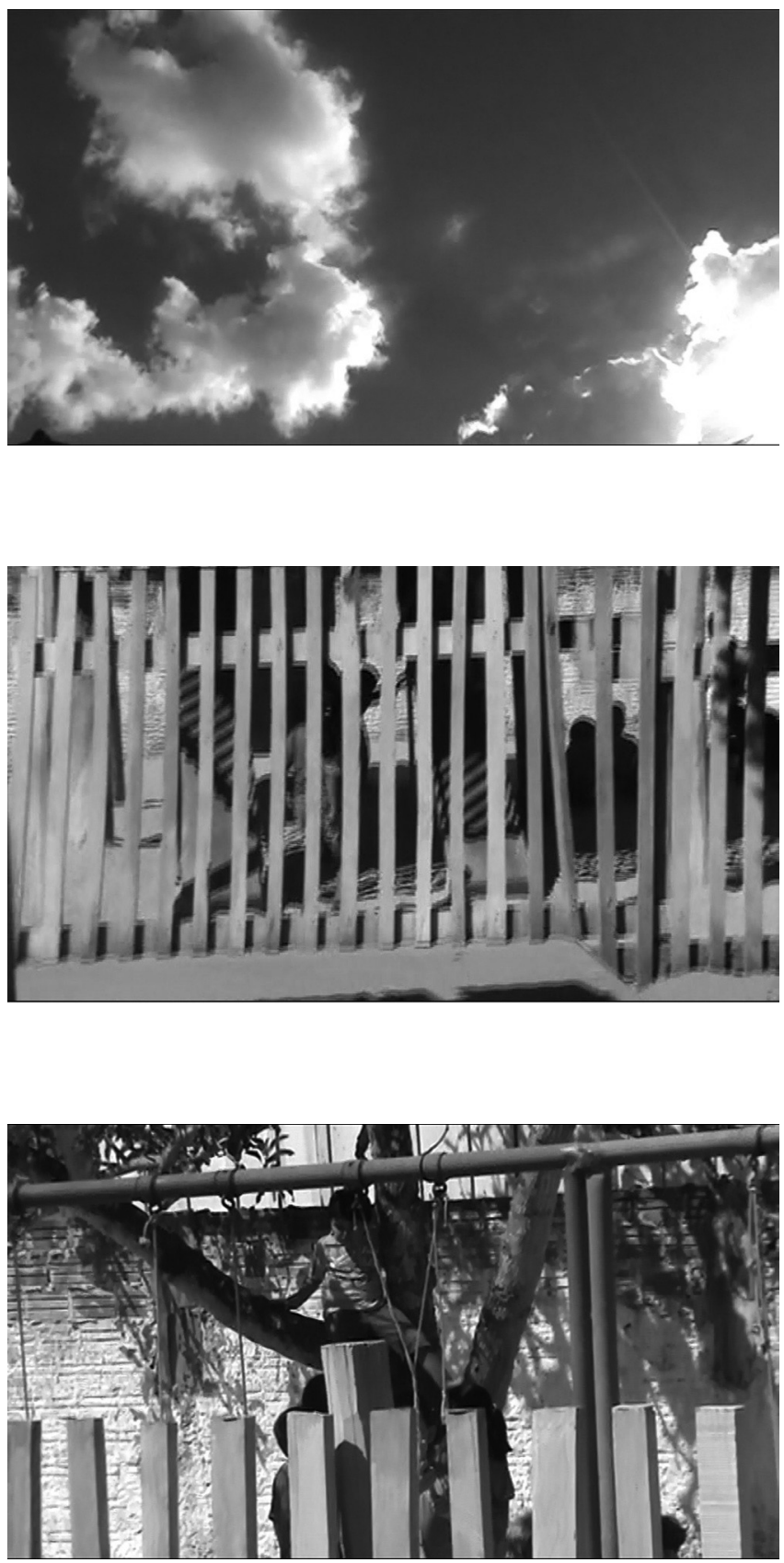


\section{BIANCA SANTOS CHISTÉ}

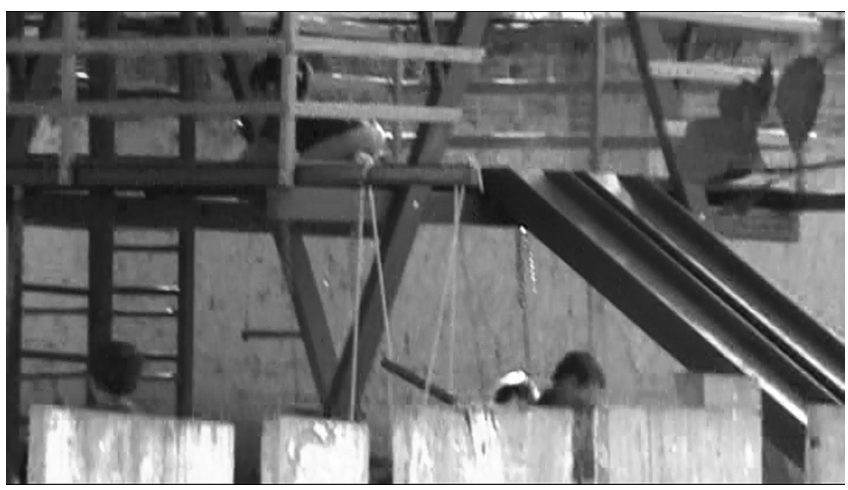

Fonte: <https://www.youtube.com/watch?v=nJMLqDeSECc $>$

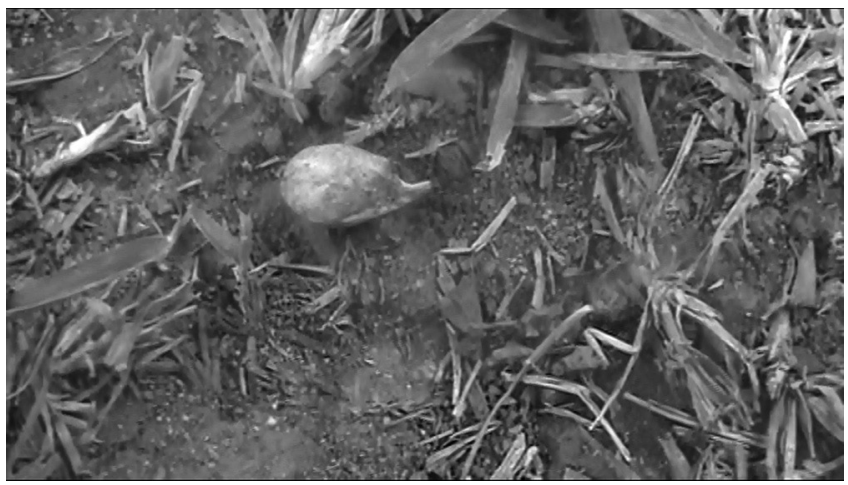

(Pré II, 2012)

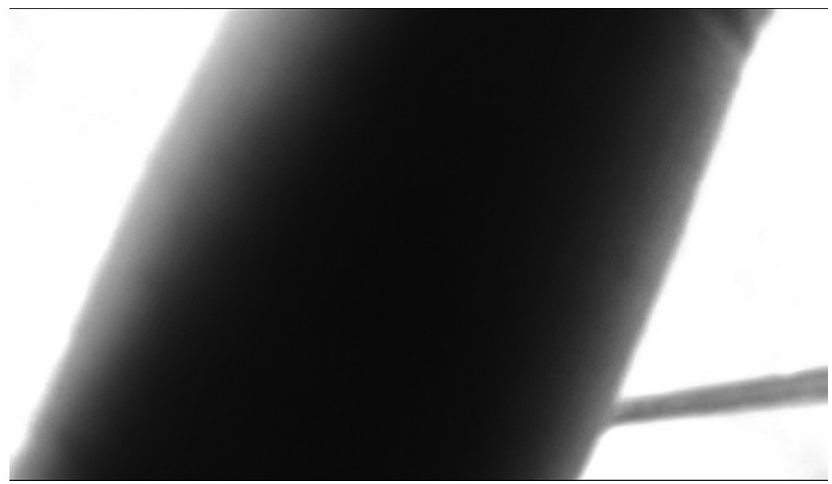



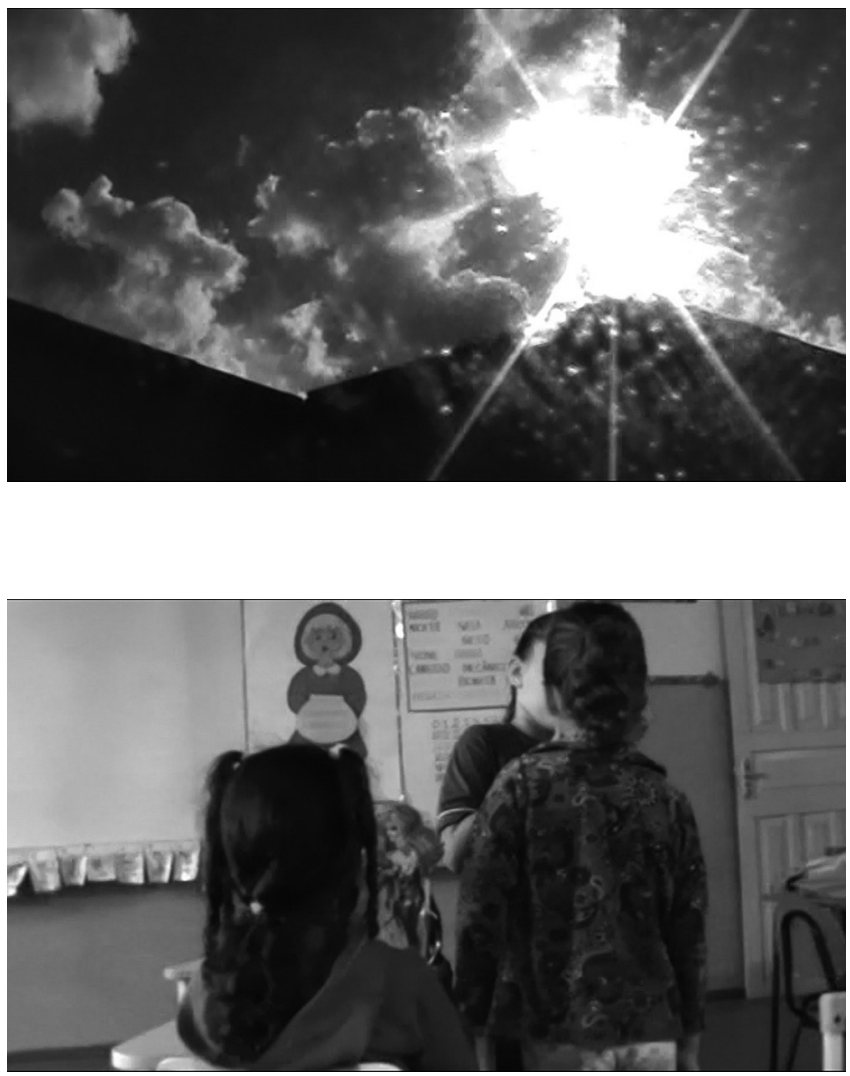

(Pré II, 2012, 10²1)

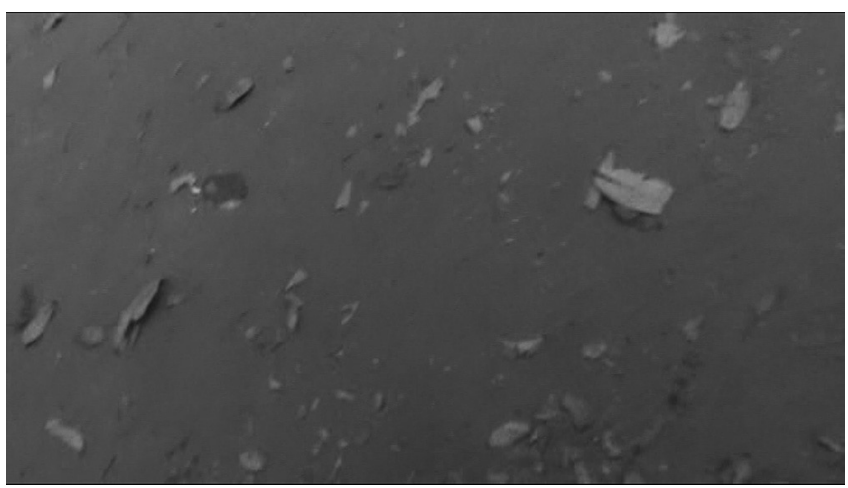



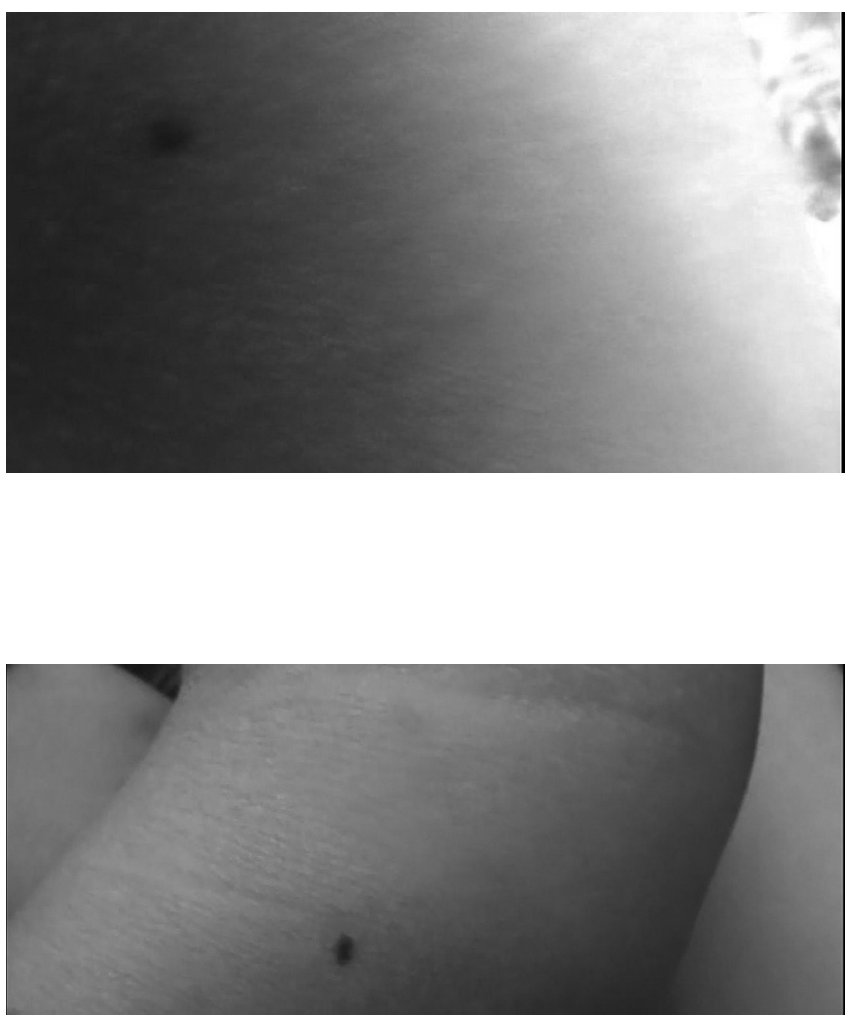

(Pré I, 2012, $3^{\circ}$ 20)

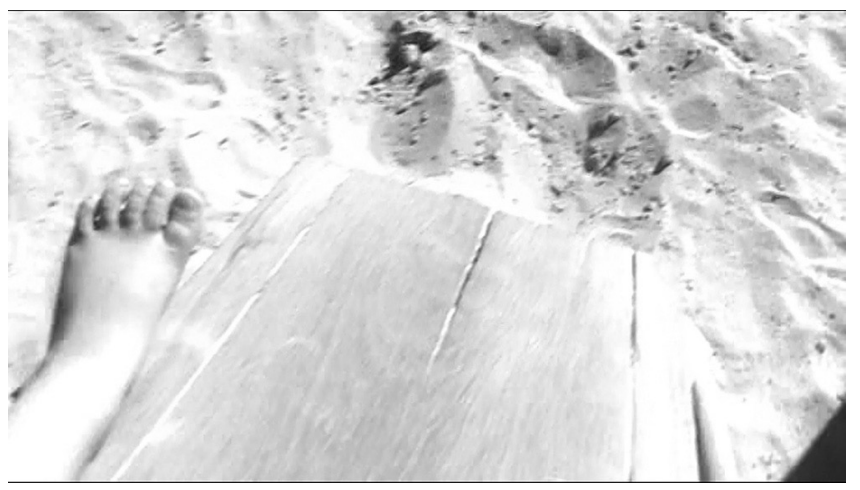

(Pré II, 2012, $2^{\circ}$ 6) 
INFÂNCIA, IMAGENS E VERTIGENS 83

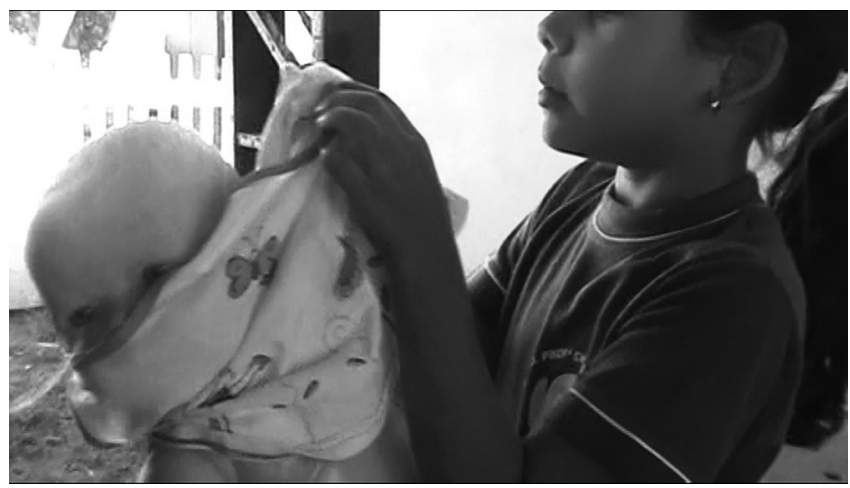

(Pré II, 2012, 2²)

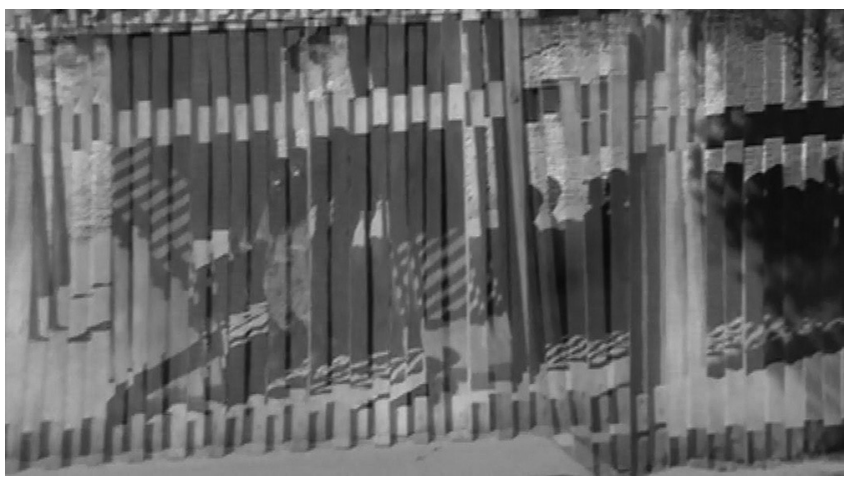




\section{3 \\ RASTROS DE PROPOSIÇÕES CRIANCEIRAS}

Eles ficam comendo bostas [...] Eles ficam vendendo bostas na rua. Mas não é bosta assim de cachorro não, é bosta comida.

(Pré I, 2012, $3^{\circ}$ 20)

\section{Um não-lugar infantil atravessante}

Gostaria de começar esta escritura com um poema de Manoel de Barros (2013, p.), "As coisas não querem mais ser vistas por pessoas razoáveis: Elas desejam ser olhadas de azul, Que nem criança que você olha de ave". Parece que com crianças, ou dizendo de maneira mais ampla, com infâncias, podemos olhar de ave, um olhar azul, um simples olhar, um olhar com mais atenção, um olhar menor. A criança, ou a infância têm esse "defeito de nascença” olham o mundo de outra maneira. Uma maneira diferente do adulto. A criança não habita um outro lugar. Mas coexiste no mundo com suas vivências, seus saberes, suas imagens, seus desejos. Se houvesse mundos, diria que a criança, coexiste junto, em paralelo conosco. 
No mundo em que vivemos, o termo paralelo divide hemisférios, ações, atividades, posições. Ou ainda, é o que se diz, em geometria, de duas ou mais linhas ou superfícies que se conservam a igual distância umas das outras em toda a sua extensão. Indica também, de modo figurado, duas ou mais coisas que caminham a par ou progridem na mesma proporção. O que menos importa aqui é o conceito em si, mas sim naquilo que ele nos permite pensar, no espaço aberto pelo conceito para a criação de novos pensamentos.

Então, falar de paralelo, universo paralelo, não é falar somente de lugares e universos distintos, diferentes. Implica dizer que o habitante deste lugar, deste universo estabelece relações ou não com outros lugares, em lugares, em algum lugar, entre lugares. Esse lugar pode ter maior ou menor extensão, pode estar lado a lado, junto, separado, sobreposto, equidistante. E ao mesmo tempo, não é um lugar a parte, à deriva, à mercê. Ou dizendo de outra forma, enquanto a vida Cronos se desenrola, as crianças percorrem outros tempos, outros espaços, outros sentidos de maneira estupefata e imprevista. São nessas relações com o mundo que as crianças são atraídas por outros interesses, interesses pequenos, interesses menores, por restos, resíduos, pedras, madeiras, retalhos, ruínas.

Com isso, nos diz Benjamin (1987, p.16) "as crianças formam para si seu mundo de coisas, um pequeno no grande, elas mesmas”. Ou seja, a partir disso, as crianças constroem mundos, seus e outros mundos, mundos outros, mundo 'di-menor', um mundo delas, para elas. Ou como diz Leite e Leite (2014, p.06) "É um mundo que possui sua própria lógica, mundo esvaziado da lógica adulta que sempre se impõe sobre o mundo das crianças, mas um mundo que não 'se organiza', não 'se arruma' em referências dadas antes de uma lógica já dada, mas 'lógicas de outros tempos e outras razões', um mundo inseguro e irascível”. 
Um mundo coexistindo junto ao mundo cronológico, todo-poderoso, que lança sobre nossas vidas seu olhar tirânico a fim de devorá-las. As crianças, a infância destronam Cronos, indagam-no em suas certezas, em suas verdades; entra em outra relação com o tempo, o tempo aión, um tempo aiónico, que designa a intensidade do tempo da vida humana e não uma continuidade da vida como etapas cronologicamente definidas, estabelecidas, numerável: um tempo experiência, tempo-infância, com uma temporalidade não numerável, nem sucessiva, intensiva.

As crianças, a infância resistem ao reinado de Cronos, aos movimentos centralizadores, totalizantes, disciplinadores, impostos cada vez mais cedo na vida delas. Diante do mundo adulto, junto ao mundo adulto, de uma performance adulta, as crianças, as infâncias traçam seus próprios caminhos "nas florestas das coisas, dos atos e dos signos" (Rancière, 2012, p.20) que estão diante delas ou as cercam. Elas se lançam em uma aventura intelectual, em novas aventuras intelectuais que não se assemelham a nenhuma outra e vão além da realidade vivida, elas transveem o mundo, quebram as regras estabelecidas. Elas mudam a ordem das coisas, vira-as pelo avesso, de profana usos e des-usos do que é sacralizado, de des-criam o que existe. É somente profanando que as crianças e a infância resistem à instrumentalização e à docilização de seus corpos, de seus pensamentos, de sua linguagem.

As crianças, entre iguais, se organizam, organizam forças para se relacionarem por si mesmas. Nessa relação elas pensam, produzem, criam, des-criam e são ouvidas por seus pares. São ouvidas, falam, entram em interlocução, que vai além das palavras pelas palavras. É a partir disso, que as crianças veem o que o adulto não vê mais, percorrem trilhas que os adultos não mais trilham e antes não percorridas, abrem brechas e fendas, decifram signos e enigmas, ou seja, como afirma Gagnebin 
(2005), aponta para verdades que os adultos não querem mais ouvir.

Parece que esse jeito de ser criança, essa condição infantil perturba o adulto, ao ponto de querer dominá-la, domesticá-la, controlá-la. Parece que as crianças, a infância, se incomodam pouco com o adulto, com o mundo pensado pelo adulto. Parece que os adultos são mais afetados pela condição infantil do que o contrário, pois as crianças, a infância, alteram a ordem e a lógica adultícia. Se tomarmos as imagens produzidas pelas crianças em uma instituição de educação infantil o que vemos são imagens trêmulas, embaçadas, imagens nítidas e sem sentido, imagens vazias, imagens desfocadas e focadas, imagens deslocadas, vertiginosas, que muito e pouco dizem. Imagens que profanam a ordem do dia, a ordem das coisas, os sentidos dados, estabelecidos, imagens infantis, imagens lúdicas que nos mostram muito das experiências infantis, em que me parece, essa coexistência se configura.

Tomarei como ponto de conversa as imagens capturadas de um dia de filmagem (pré-escola II, 14/08/2012), realizada pelas crianças, na qual a criança Matheus e mais dois colegas são protagonistas e Nicole a responsável por registrar o achado, para pensar um pouco mais o movimento de acontecimentos coexistentes junto ao tempo curricular. Matheus chega com a mochila nas costas e um saquinho de plástico nas mãos. A aula já começara ele procura seu lugar para sentar. Seu caderno para a realização da atividade já se encontrava sob a mesa. Tão logo se localiza na sala e com a tarefa a cumprir, que naquele dia foi desenhar as pessoas que fazem parte da família, que moram na mesma casa, Matheus, sempre com o saquinho na mão, inicia o cumprimento da atividade. Eis a rainha Chronilda imperiosa ordenando os ritos e as regras: aquele momento é de realizar a atividade. 
Apesar da tarefa, Matheus não desgruda do saquinho. Mesmo antes de terminar a atividade, guarda o caderno embaixo da mesa e abre a sacola que tem em mãos e tira lá de dentro um jogo de percurso, com um dado e três carrinhos de papel. Sempre olha para a professora verificando se ela não esta o observando. Primeiramente o chão da sala de aula é o lugar para início da brincadeira, entre as fileiras, por pouco tempo, ele garante que a professora não o encontrará. Parece que as crianças conhecem os três princípios básicos de toda arte de esconder, como trata Benjamin (1987, p.226), no qual o terceiro é "O princípio da altura e da profundidade. [...] as pessoas fitam em primeiro lugar o que esta a altura dos olhos; depois olham para cima e só por último se preocupam com o que esta a seus pés".

As fileiras aqui lembram um dos textos de Benjamin (1987), quando ele nos apresenta uma criança atraída pelo esconderijo. A criança de Benjamin, em Esconderijos, conhecia todos os esconderijos, no qual podia passar despercebida, nessa aventura ela encerrava-se em um mundo material que ia se transformando conforme suas fantasias. Ela se disfarçava para não ser descoberta. Mas, o receio de ser descoberto rompendo com as regras do dia perde força quando Carlos e Marcelo se aproximam e eles sem receio nenhum se acomodam em pé a uma das mesinhas. Carlos pega o dado e diz Olha você tem que pegar aqui. Mateus responde eu já sei, eu já sei, e coloca o dado sob a mesa. Marcelo diz que quer brincar também. E o pequeno guia dos esconderijos continua, as crianças passam do chão, onde estavam localizados entre as fileiras, para a mesinha, pois de alguma forma sabem que "quanto mais livremente estiverem expostos a todos os olhares, tanto melhor" (Benjamin, 1987, p.225). O segredo aqui é tornar-se exposto, tornar exposta a atividade "proibida" para o momento, pois, quanto mais estiverem à vista da Rainha Chronilda, menor a possibilidade de serem flagrados. 
Então, iniciam a discussão de quem começaria a jogar o dado primeiro. Matheus decide então começar, mas, desiste logo em seguida, passando a vez para o Carlos, dizendo, tem que jogar aqui na mesa. Carlos joga, o dado cai no lado que tem dois. Os meninos nem contam, batem os olhos e logo falam, tem dois, tem dois. Matheus mostra o caminho no percurso e diz tem que andar dois. Em seguida pega o dado entre as duas mãos, sacode e lança o dado. Cai na quantidade um. Matheus aponta para o Carlos e diz ele tá na frente. Na vez do Marcelo cai no número cinco. Eles contam a quantidade no dado apontando com o dedo e em seguida, Marcelo "anda" cinco casas. O jogo, a brincadeira é interrompida quando Chronilda chama as crianças para formarem a fila para o lanche. Matheus então, rapidamente coloca o material levado de casa de volta à sacola, pois por "nada neste mundo eles poderiam ser descobertos".

Com a ajuda de Agamben (2005, p.85) digo que é "brincando, que as crianças, a infância, desprendem-se do tempo sagrado e o esquecem no tempo humano". Ou seja, por meio da brincadeira, ou no "Pais dos brinquedos", como nos diz Agamben, as crianças entram em uma "outra dimensão do tempo, na qual as horas correm num lampejo, e os dias não se alternam”. Elas profanam a sacralização do mundo, do tempo Cronos estabelecido. O tempo criança, o tempo infância caminha junto, coexistindo juntamente ao tempo Cronos, alterando-o, destruindo-o.

Aqui, Rancière (2012) também nos provoca a pensar, com as imagens, as crianças, a infância, como produtora ativa e não como espectadoras passivas diante do tempo cronológico, linear, controlado. As imagens produzidas pelas crianças abre a possibilidade de olhar o corpo, a exposição dos corpos, movimentos, corpos em movimentos, corpos deslocados, corpos que falam, vibram, gritam, corpos produtivos, corpos produtivos lançados 
em aventuras intelectuais em outros tempos: tempo kairológico, tempo aiônico, tempo acontecimento, tempo experiência, tempo não previsto, tempo indecisivo e indefinido.

A infância, as crianças são povoadas por devires; elas brincam com a desordem das palavras e das coisas, inventa mundos, descortina o olhar cristalizado das coisas, atuam em outra temporalidade, ou seja, não cessam de afirmar, de anunciar devires: devir-pai, devir-mãe, devir-filha, devir-bicho, outros e inumeráveis devires. Em uma das produções imagéticas das crianças (pré-escola II, 14/08/2012), algumas meninas, durante a realização da atividade estabelecida pela professora, locomovem-se entre as carteiras, entre elas e tornam-se, sem necessariamente ter um ponto de início, a ser mãe e filhas. Estabelecem, entre elas, a idade de cada uma e dentro de um mundo menor (o mundo pensado por elas), inserem-se em um mundo maior (a escola). As meninas conversam entre si, passam batom, são mãe e filha. A mãe precisa levar as filhas para a escola. Estabelecem a idade de cada filha, Isabelli diz: eu tenho 14 anos, Maria Eduarda (a mãe) diz para Débora: você tem 5 anos, 5 anos não porque 5 você já tem, você tem 3 anos. Beatriz e Isabelli conversam sobre a idade de Beatriz e Isabelli diz: você tem 10 anos, não 10 não, você tem 8. Beatriz concorda com a idade.

Mesmo diante da interrupção para o retorno à tarefa dada, elas, ao dirigirem-se umas as outras, tratam-se a todo o momento como mãe e filha. Débora chama Maria Eduarda de mamãe e Maria Eduarda chama Beatriz, Isabelli e Débora de minha filha. Elas não se parecem com mãe e filha, não equivalem a mãe e a filha, nem imitam a mãe e a filha, nem se identificam com elas, pelo contrário, são as próprias, mãe e filhas. Organizam-se junto ao tempo escolar, sucessivo, numerável, organizado, junto a tarefa escolar, para experienciarem o acontecimento de 
tornarem-se outrem - mãe e filha. Elas desprendem-se da escola pensada pelo adulto, dos eventos dados, da relação cronológica do tempo, da linearidade, e cria novos cenários, novos eventos, novos devires, procurando com isso, no interior dos códigos impostos, demolir as verdades dos discursos que pretendem fabricar o conformismo.

Ao desprenderem-se do tempo que habita a maioria dos fazeres da escola, elas tornam-se invisíveis, talvez, sentem-se invisíveis, como diz Alice (Carroll, 2002, p.139), "Acho que não podem me escutar [...] eu tenho quase certeza de que não podem me ver. Alguma coisa me diz que estou invisível". Poderia dizer, que é uma invisibilidade dentro do visível, pois para Deleuze e Guattari (1997, p.74) "esconder-se, camuflar-se, é uma função guerreira”. Ou ainda como diz Schérer (2009, p.131) "ao usar o visível para se tornar invisível aos outros, ela escapa à vigilância deles”. O jogo talvez seja exatamente esse, quanto mais expostas a todos os olhares, a todos os videntes, melhor a possibilidade de não serem vistas. Enquanto a aula se desenrola, enquanto a aula "caminha" elas, crianças, transitam e deslizam com rapidez entre as fronteiras, entre as tarefas, entre o estabelecido, constituindo devires, acontecimentos, encontros que duram um piscar de olhos, por isso, imperceptíveis, por isso, quem sabe, inalcançáveis.

Aqui, ao pensar em fronteiras, em territórios, em crianças e infância, Leite (2013, p.5) diz que:

falar de fronteiras é falar de certo 'entre', a fronteira não ocupa necessariamente um espaço único e nem sempre linear, a fronteira parece ser algo que de alguma forma está 'entre' duas partes, entre dois lugares (geralmente fixos, estáveis), a fronteira tangencia os lugares, corta os lugares e ao mesmo tempo que indica os limites de cada lugar é também o espaço possível de passagem, é um espaço 'entre', de modo 
geral, podemos dizer um 'entre' nações, entre territórios, entre lugares fixos, dados, identitários.

As crianças, ou dizendo de maneira mais ampla, a infância transitam pelas fronteiras, entre as coisas. Em outra produção imagética durante o lanche da manhã, um grupo de crianças prefere não lanchar e aguarda as demais lancharem. Essa foi a oportunidade para cinco crianças discutirem sobre suas idades. Pedro inicia o diálogo, tendo a idade como temática, dizendo à criança operadora da câmera e às demais crianças ao seu redor:

Eu tenho cinco anos - mostra a mão aberta com os cinco dedos. Eu tenho cinco anos - agora mostra a mão aberta para a câmera. Meu irmão tem seis - diz João.

Tia, oh tia (fala chamando a minha atenção) Sabe quantos anos eu fiz? Eu fiz assim oh (mostra seis dedos) seis anos. Foi meu aniversário de seis anos. - diz Patrícia

Fiz seis anos - diz Patrícia para João.

Um, dois, três, quatro, cinco, seis, sete, oito, olha depois do oito vem o nove, depois do nove vem o DEZ. Diz João contando nos dedos. Dá risada e diz:

Nossa velho!! (Pré II, 2012, $1^{\circ}$ 1)

Diante da espera, no espaço e momento (refeitório e hora do lanche) onde se exigem insistentemente das crianças silêncio, mesmo aquelas que optam por não comerem, elas conversam entre si, falam, pensam, produzem sentidos, sentidos outros, transformam uma possibilidade de inércia em encontros com outras crianças e consigo mesmas. O espanto expresso em Nossa Velho!, apresenta muitas descobertas e nos indica que o lugar fronteiriço é também um lugar de desejo, de escolhas, de liberdade, de encontro com o outro e consigo mesmo, é lugar, é o entre-lugar de luta pela sobrevivência do pensamento que se coloca em 
movimento para inventar possibilidades outras de pensar o mundo. É também o espaço, como afirma Larrosa (2006, p.62) de "obstáculo e promessa, fechamento e abertura". Os enredos das crianças nos apresentam essa linha tênue, esse espaço instável, perigoso, no qual as crianças rompem e se arriscam desafiando e modificando as normas e as regras adultícia. De acordo com Larrosa (ibidem, p.69),

As crianças atravessam a fronteira, para um lado para o outro, simplesmente porque vivem nela e dela. A fronteira não é disjunção nem conjunção, senão um território perigoso no qual as crianças têm que usar todo seu valor, toda sua habilidade e toda a sua solidariedade para viver. [...] A fronteira é um perigo para a sobrevivência e, e, ao mesmo tempo, uma oportunidade para a sobrevivência

As crianças estão sempre percorrendo fronteiras, percorrendo entre-lugares, indo para algum lugar, apesar de parecer que fazem isso sem direção, sem rumo. Elas também estão sempre com pressa, embora pareça que pouco se preocupam com tempo e onde vão chegar. Nesse movimento, no entre, as crianças são rápidas, ou como nos diz Deleuze e Parnet (1998, p.42) "as crianças são rápidas porque sabem deslizar entre”. Elas não cessam de explorar os meios, os trajetos, deslocam-se incessantemente. Elas sempre saem do lugar que insistem em colocá-las, fixá-las, amordaçá-las - o lugar da imobilização do corpo, o lugar da surrupiação do pensamento. Além disso, resistem aos modelos dados, à massificação da palavra, dos sentidos generalizantes, como faz Humpty Dumpty (Carroll, 2002, p.204), "Quando eu uso uma palavra, disse Humpty Dumpty num tom bastante desdenhoso, ela significa exatamente o que eu quero que signifique [...] a questão é saber quem vai mandar - só isto". As crianças usam palavras que ainda não tem idioma, livram as palavras das 
amarras da língua. As crianças estão sempre nomeando as coisas por conta própria, às vezes chegam mesmo a serem bilíngues em sua própria língua.

Elas transgridem tudo, incluindo a linguagem padronizada: dizem coisas como amarrador em vez de presilha, filmador em vez de camera-man, "camera aî" em vez "filma aí", relampião no lugar de relampejando, ou simplesmente brincam com a desordem das palavras, como filmeimagnol, mepapipipabá; ou ainda dizem coisas assim: "tem uma menina que tem um dente, é uma dentadura de boca" (palavras capturadas das filmagens dos dias 10 e 31 de maio de 2012). Isso indica que as crianças, transformam, transgridem, dessacralizam, o sagrado, o sacramentado, ou como diz Agamben (2007), profana, todo ou qualquer objeto que estiver a seu alcance. Por meio da profanação elas deformam o uso comum das coisas, tocando no sagrado para libertá-lo, fazendo, criando, inventando assim, um novo uso.

Em linhas gerais, as produções imagéticas levam a pensar que as crianças, não só habitam outros mundos, outros lugares, mas que esses lugares caminham, ao mesmo tempo, no mesmo lance, junto e separado do mundo adulto. Habitam ao mesmo tempo os mundos, os lugares. Parece que seria uma caminhar, um habitar nos dois sentidos (em todos os sentidos) ao mesmo tempo, quer dizer, as crianças não habitam outros lugares, não caminham junto ao adulto, sem se afastar dele, sem atravessar os caminhos, sem percorrer as fronteiras e inversamente. Coexistem, coengendrados, como palavra que mora no peito e dorme lá até se tornar intimidade. Seria como se habitassem lugares ao mesmo tempo. Quando o caminhar, o habitar, o estar junto ao e separado de, começam a fundir-se, quando os limites desses territórios são rompidos, todo lugar, toda territorialização se perde para não-lugares e as crianças deslizam entre-lugares sem se deterem. 


\section{O des-sentido do corpo}

Os movimentos dos corpos, contidos nas imagens, nos apresentam crianças que se deslocam de lugares, de posições (não é mais a escola, a aluna, a colega), nos apresentam corpos em movimento, movimentos dos corpos. Os movimentos apresentam corpos que pensam, ou como diz Leite (2013), crianças que pensam pelo corpo. Pensar pelo corpo, pensar com o corpo é mobilizar todas as extensões, os músculos, as articulações, as glândulas, os membros, os órgãos, os sistemas, os ossos, as moléculas, as partículas, as sensações, os sentidos. Pensar pelo corpo e com o corpo, corpo pensante, é fazer circular o pensamento em todas as extremidades, em toda interioridade, em toda exterioridade, é afetar e deixar-se afetar. É romper com um modo, um modelo, uma forma predominantemente cognitiva presente na educação, na educação matemática, na matemática.

Pensar pelo corpo, com o corpo é ocupar outros lugares, é tornar-se outros, é assumir outras formas, realizar núpcias, encontros com outros... órgãos, membros, sentidos, moléculas, partículas, corpos. Pensar pelo corpo, com o corpo é sair do lugar, romper, afrontar, enfrentar, colocar-se na berlinda, correr riscos, arriscar-se, encantar, ousar. São corpos que se misturam e misturam, se encontram e encontram, se mobilizam e mobilizam, se tocam e tocam, se afetam e afetam, que experimentam e se experimentam, que movem e se movem, que comovem e se comovem.
O corpo provoca o pensamento, o meu pensamento
O corpo dá o que pensar, me faz pensar
O corpo afeta, me afeta
O corpo toca, me toca
O corpo pulsa, o corpo pensa 
As imagens produzidas pelas crianças em situação não controladas, não pré-determinadas por outro, pelo outro, pelo adulto, levam a pensar que, com as crianças, com a infância, o corpo, os órgãos, os sistemas e tudo o mais, mudam de funcionalidade, elas mudam o sentido, invertem-nos, inventam outros e novos sentidos. Ao olhar suas produções imagéticas, me parece que as crianças, não utilizam o corpo somente da maneira que fomos personificados a usá-lo, a partir de uma ideia definida, fixa, medida, que determina formas e modos de sentidos: os olhos são para ver, a boca é para falar (ou comer pela boca), os pés são para andar, as mãos são para pegar, os ouvidos são para ouvir, o corpo, a pele, não são para serem tocados.

As crianças e as imagens apresentam possibilidades outras de sentidos e não sentidos do corpo libertam o corpo de ter apenas uma função, um uso, um sentido, de ser apenas um organismo encampado pela biologia. As crianças salvam o corpo da pobreza de ser apenas corpo. Parece que as crianças não aceitam que a porta possa ser aberta somente com as mãos, que as coisas possam ser seguradas somente com a mão, que olhos sirvam apenas para olhar as horas, sirva apenas para olhar a tarefa no quadro, que vê a uva, que com os pés seja possível apenas caminhar. As crianças me apresentam possibilidades outras: as crianças falam pelos pés, pés que falam; andam com a bunda, bundas que andam; veem com o ouvido, ouvidos que veem, ouvem com as mãos, mãos que ouvem, sentem com os olhos, olhos que sentem; tocam com a boca, os pés, com as pernas, as orelhas, os olhos, as mãos; boca, pés, pernas, orelha, olhos, mãos... que tocam e são tocados.

Em um mundo em que o corpo vai sendo ajustado a uma ideia antecipatória, que o leva a reproduzir ideias, a criança, ou dizendo de outra maneira, o corpo-criança desajusta a ideia de reprodução resistindo-a. As produções imagéticas das crianças nos apresentam corpos 
vivos, vibrativos, vibrantes, ativos e corpos sensíveis. Corpos sensíveis a outros corpos, a outros movimentos, corpos abertos, corpos acordados, corpos enchidos das sensações do corpo diferentes dos corpos subtraídos da educação infantil. São esses movimentos dos corpos, são esses encontros de corpos que singularizam o acaso, singularizam os caminhos, singularizam as possibilidades e que perpetua a existência humana.

Olha, olha Kamilly...

O que?

Olha minha pele, minha pele está toda riscadinha!

Além disso, as produções imagéticas me possibilitam pensar também a intimidade, a intimidade dos corpos em um mundo adulto onde o não me encoste, o não me rele está explícito e implícito. Elas estão sempre muito próximas, se esbarrando, se encostando, descansando a perna, o braço, os pés, as mãos umas nas outras. Parece que os corpos são atraídos uns pelos outros. São corpos entrelaçados, corpos misturados, entrecruzados, corpos ímã, corpos grude, corpos gosmas. Muitas vezes essa junção, quem sabe essas núpcias dos corpos, apresentam uma realidade extensiva de corpos. Às vezes é difícil separar onde começa e termina um corpo, às vezes é impossível determinar a quem pertencem os corpos (pernas, braços, pés, olhos etc.), é como se um corpo, nos dirá Deleuze (2011, p.06), ao tocar outro coexistisse com ele em todas as suas partes, "como fogo no ferro ou como a gota de vinho no mar".

A maior riqueza do homem

é a sua incompletude.

Nesse ponto sou abastado.

Palavras que me aceitam como sou - eu não aceito. 
Não aguento ser apenas um

sujeito que abre

portas, que puxa válvulas,

que olha o relógio, que

compra pão às 6 horas da tarde,

que vai lá fora,

que aponta lápis,

que vê a uva etc. etc.

\section{Perdoai $^{1}$}

\section{Mas eu preciso ser Outros.}

Eu penso renovar o homem usando borboletas.

Barros (2013, p.347 - 348)

A criança, o corpo-criança, o deslocamento, o movimento do corpo apresenta resistência à docilização, à repressão, à disciplinização, à colonização de seus corpos e também de seus pensamentos. É sob uma cadeira, sob a exigência de retidão corporal, de corpos aprumados e retos, enfileirados, que a escola tenta subtrair o corpo, imobilizar, enquadrar, engessar, cristalizar, dominar, o corpo e, por conseguinte o pensar, o pensamento. Parece que a mente está matriculada na escola, e o corpo que a transporta, sede da cognição, incomoda, por isso, o dominam, o regulam, o expulsam. "O controle da sociedade sobre os indivíduos não se opera simplesmente pela consciência ou pela ideologia, mas começa no corpo, com o corpo. [...] O corpo é uma realidade biopolítica”, nos diz Foucault (1985, p.80), ou seja, é com o corpo, pelo corpo, no corpo, que os agentes reguladores (escola, família, hospitais, igreja, prisão etc.) controlam, regulam, moldam modos de ser e estar no mundo, a própria existência do ser, com o intuito de ajustar a desajustada vida, de tornar

1 Destacado pela autora. 
o futuro mais adequado, mais suficiente, mais quem sabe, mais eficiente.

Filma as formiguinhas trabalhando.Olha o que eu achei, olha o que achei. É seca, é dura!

Ela corta, cuidado tá!

Num corta não!

Corta sim!

Não corta!

Ela corta sim!

Deixa eu ver. Pega na folha, sente a folha, toca a folha, Corta sim, nessa ponta corta.

A folha passa pela mão de todas. Algumas fazem isso ao mesmo tempo, mas todas pegam na folha, sentem a folha. Se você forçar corta.

Isso não é espinho. - toca a ponta da folha

Mas é espinho duro!

É uma folha.

É uma folha e ficou dura, né.

É da árvore, né. Elas caem, mas ninguém mede. Mas se alguém mexer não fica assim, se alguém não mexer fica assim, ai deixa lá e o guri pode pegar na mão. Mas não pode pegar dessa pontinha aqui, dessa pontinha não.

Pensei que tava verde, se fica verde.

(Pré I, 2012, $3^{\circ}$ 21)

Os corposcrianças são atraídos por outros corpos, corpos de naturezas diferentes, corpo-natureza, corpo-chão, corpo-semente, corpo-formiga, corpo-folha... As crianças são seduzidas pelos seres pequenos, pelos pequenos seres, seres do chão, encontrados no pátio, no quintal, na terra, na areia, na grama. Elas percebem que o mundo, as coisas, os objetos, as palavras, não estão a nossa disposição para nos obedecer. Elas sabem que tudo isso pode ser outras coisas, que como adultos, tentamos instrumentalizar. 
As crianças veem o mundo com olhos sensíveis, por isso enxergam o invisível, o que nada mais é do que o demasiadamente visto, o não observado, o desprezível e o desprezado, tal como declara Benjamin (1987, p.16), em Canteiro de Obras, "[...] a Terra está repleta, dos mais incomparáveis objetos de atenção e exercício infantis". As crianças não só enxergam, observam, veem outros corpos de natureza outras, mas também tem uma relação íntima com eles. Os tocam, os acariciam, exploram suas formas como verdadeiras descobridoras, são tocadas por eles. Mas afinal, nos perguntaria Espinosa (Deleuze; Parnet, 1998, p.73) "o que pode um corpo? De que afetos ele é capaz?" e mais adiante Deleuze e Parnet (1998, p.74) nos diz "Os corpos não se definem por seu gênero ou sua espécie, por seus órgãos e suas funções, mas por aquilo que podem, pelos afetos dos quais são capazes, tanto na paixão quanto na ação".

Então perguntaríamos: o que pode uma folha seca caída e aparentemente sem vida? O que pode um grupo de meninas com a câmera nas mãos? Eis aqui a potência. $\mathrm{O}$ corpo-folha imanta, atrai, magnetiza os corpos-meninas, ao fazer isso, tornam-se uma realidade extensiva, é como se, um corpo ao atrair, ao magnetizar fizesse de seus objetos extensões de si mesmo. Há aqui uma simpatia, uma atração dos corpos, uma sede de amizade e convivência, como declara, Manoel de Barros (2013, p.359) "Queria propor o enlace de um peixe com uma lata". Ao serem atraídas agem como se não houvessem outra coisa no mundo, levando-as a perpetuarem-se naquilo que as atraem. Há aqui uma quase suspensão do tempo, do tempo cronológico, é nessa subversão do tempo, neste instante de "eternidade", que as crianças são provocadas a pensar. Esse encontro, essa comunhão, essa afetação de corpos - corpos sendo afetados e afetando - funciona como provocador do pensamento, como nos diz Zeppini 
(2010, p.71) "pensar não é o ato voluntário de um sujeito consciente, mas de uma violência, de um romper com a passividade da consciência, de um jogar tudo para fora dos eixos, e este movimento é provocado pelo próprio corpo e pelas intensidades que nos tomam".

Os corposcrianças afetados olham as coisas como se fosse a primeira, veem as coisas, veem o mundo como se nunca tivessem visto antes. $\mathrm{O}$ olhar da criança é cheio de expectativa, é uma olhar aberto ao desconhecido, à novidade, à descoberta. Elas examinam atentamente, olham lenta e meticulosamente os corpos que as afetam, se lançam na aventura da contemplação, como se contemplassem os corpos como obra de arte. Não uma contemplação passiva, imóvel, controlada, alienada. Mas contemplar no sentido de olhar sensivelmente o mundo, de afetar-se, de tocar-se e serem tocadas por outros corpos, compondo assim, como diz Rancière (2012, p.17) "sua própria vida com os elementos da vida que tem diante de si”. Esse encontro, essa núpcias, esses afetos, essas experiências potencializam a criação, a invenção e movimentam o pensamento.

Em um mundo contemporâneo cada vez mais expropriado de experiência, as imagens me apresentam que na infância ainda é possível viver experiências, ser tocados pelas coisas, escutar mais devagar, olhar mais devagar, deter-se nos detalhes, falar sobre o que acontece, ouvir atentamente, privar-se momentaneamente de falar, cultivar a arte do encontro. As produções imagéticas das crianças me apresentam crianças que experimentam o tempo todo, e que as experiências passam pelo corpo, pelos corpos: o corpo, a câmera, as outras crianças, o mundo a cerca, os objetos e seres do mundo. As crianças experimentam, olham detrás da fronteira, detrás da neblina, ainda que não vejam nada. 
Em dado momento, ao cruzar a perna, a bato no canto da mesa, falo aiaiai alto e massageio a perna. João Pedro que estava ao meu lado diz:

Você vai precisar de uma ambulância!!??

Então chame a ambulância porque eu estou sentindo dor.

Mas eu não sei o número, vou perguntar pra minha mãe que ta lá em casa o número da ambulância e quando você voltar ela te leva pro hospital e o médico cuida de você. Coloca aqueles equipamentos em você. Você sabe pra que serve os equipamentos? Vamos você tem um minuto pra responder!

Olho para ele pensativa e digo:

Para me curar?

Isso mesmo, pra você ficar boa e sarar. (Pré I, 2012, $13^{\circ}$ 5)

Contudo, as crianças, a infância, resistem às normas que moldam e regulam os movimentos dos corpos, de seus corpos, de outros corpos, corpos outros. Resistem a expropriação da experiência, a subtração de seus corpos, ao pensamento anestesiado, ao entorpecimento da rotina. As crianças, a infância, como Alice, no País das Maravilhas, subvertem o controle, a tridimensionalidade, as identidades fixas, a ideia de evolução, de desenvolvimento por etapas, do simples para o complexo, do conhecido para o desconhecido. Brincam, como Alice, com o tamanho dos seres, das coisas, dos objetos. Crescem, diminuem, avançam, retrocedem, mudam os corpos de tamanho, o tamanho dos corpos, seus sentidos e sua funcionalidade. Encontram lagartas, gatos e coelhos falantes. Travam conversas com Chapeleiros Malucos. Resistem, como 
Pinóquio, a tornarem-se "humanas", pois se a suposta humanidade retira do ser a liberdade, a criatividade, os des-sentidos, a inventividade, a inumanidade, o melhor é correr rápido para o País dos Brinquedos, como fez o boneco falante, pois, nos diria o coelho ao tirar o relógio do bolso do colete "Ai, ai! Ai, ai! Já estamos atrasados!".
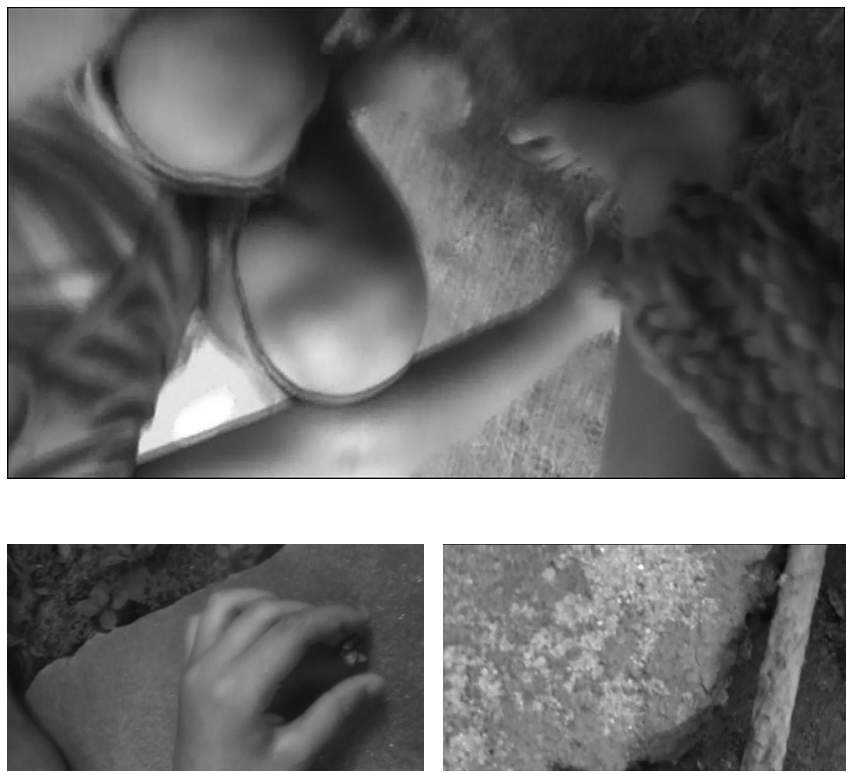

(Pré I, 2012, 55)
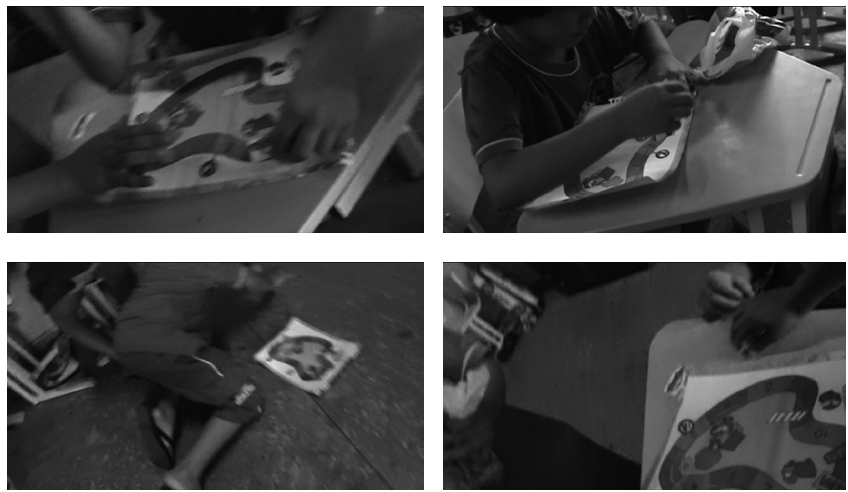

(Pré II, 2012, 105) 
INFÂNCIA, IMAGENS E VERTIGENS 105
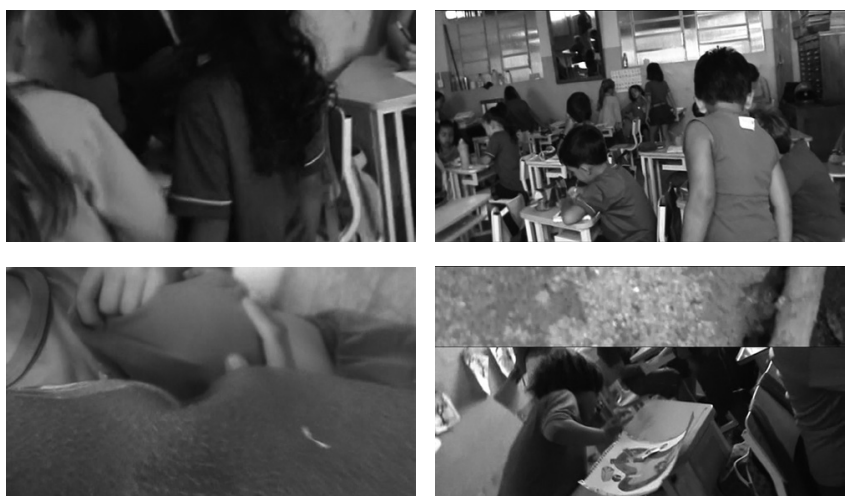

(Pré II, 2012, 105)
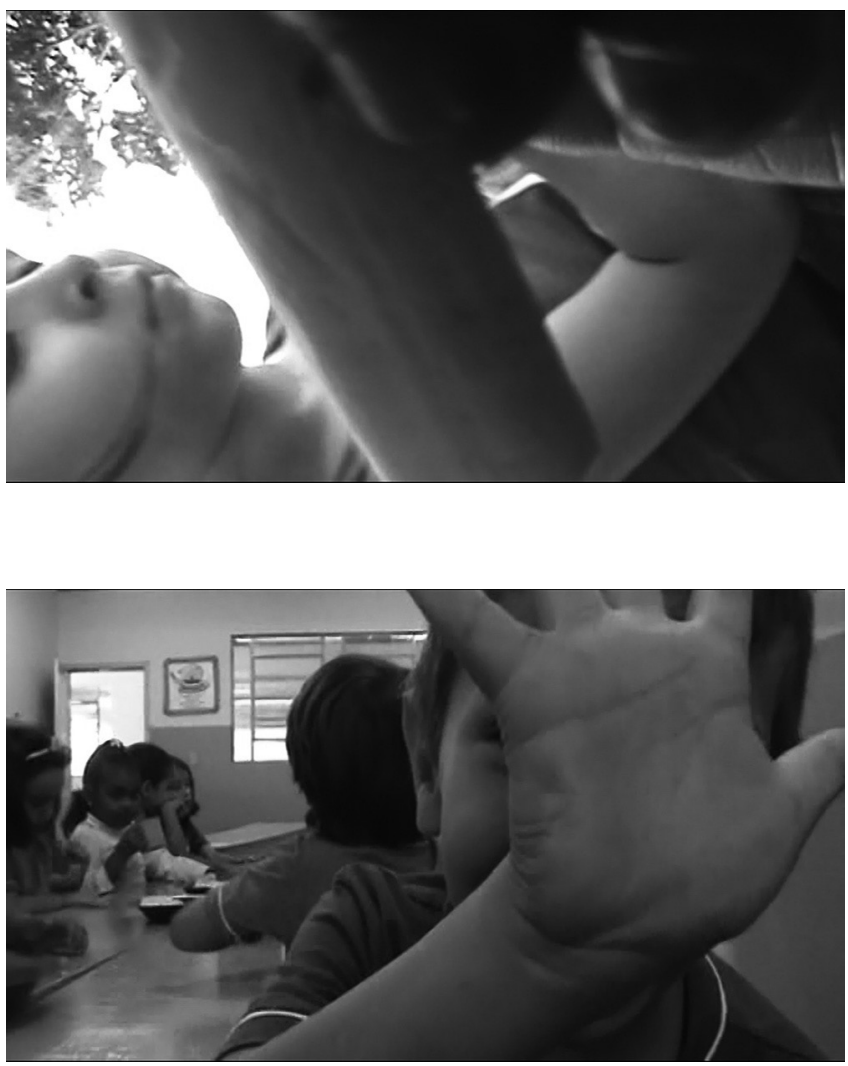


\section{BIANCA SANTOS CHISTÉ}

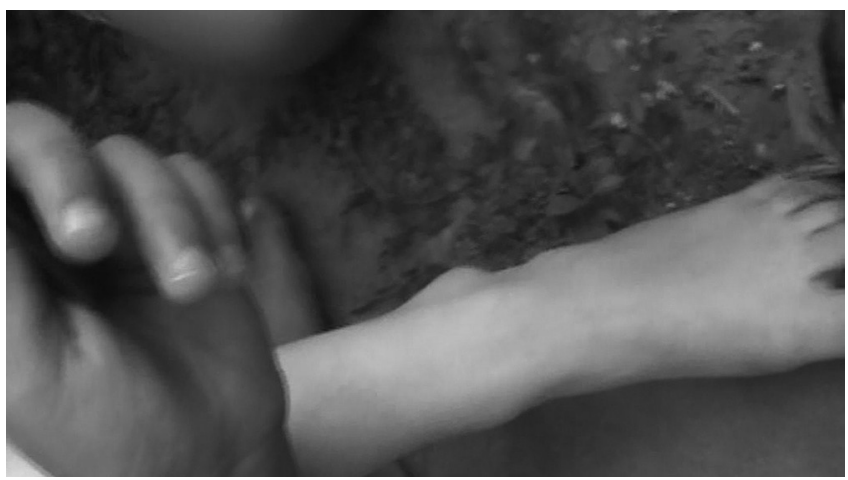

(Pré I, 2012, $3^{\circ}$ 21)
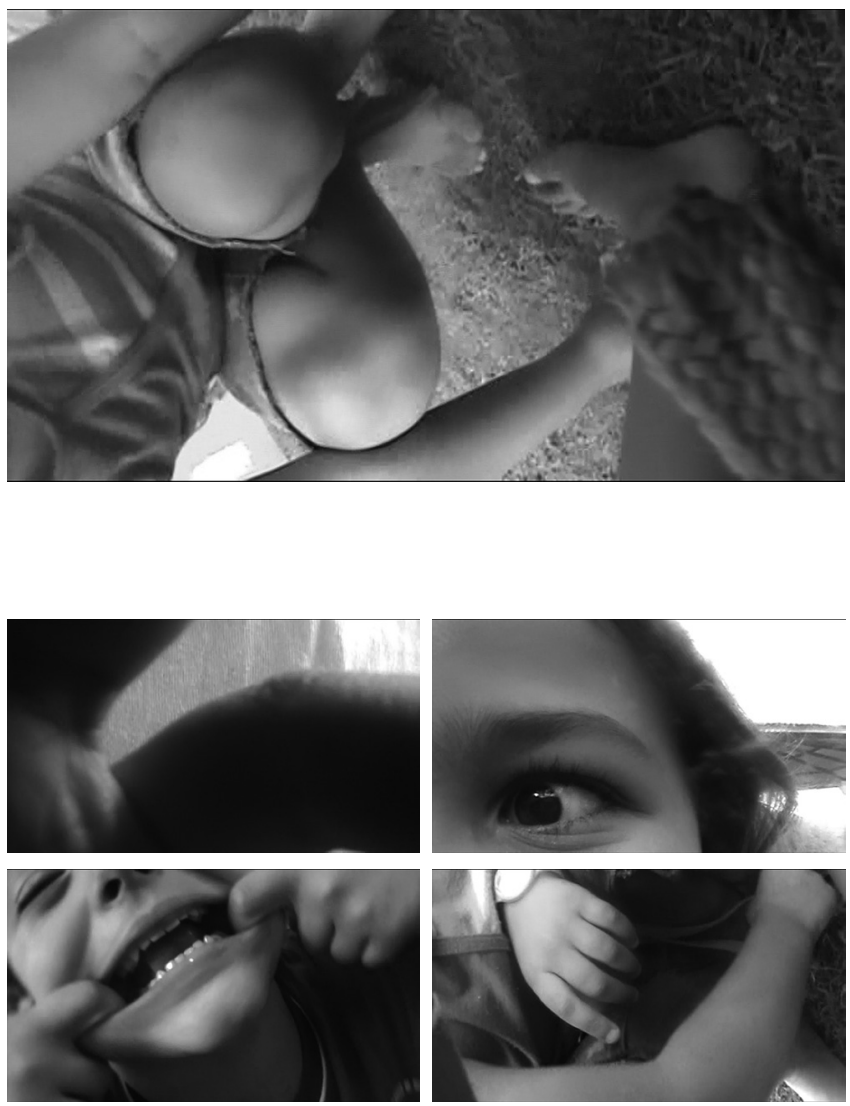
INFÂNCIA, IMAGENS E VERTIGENS 107
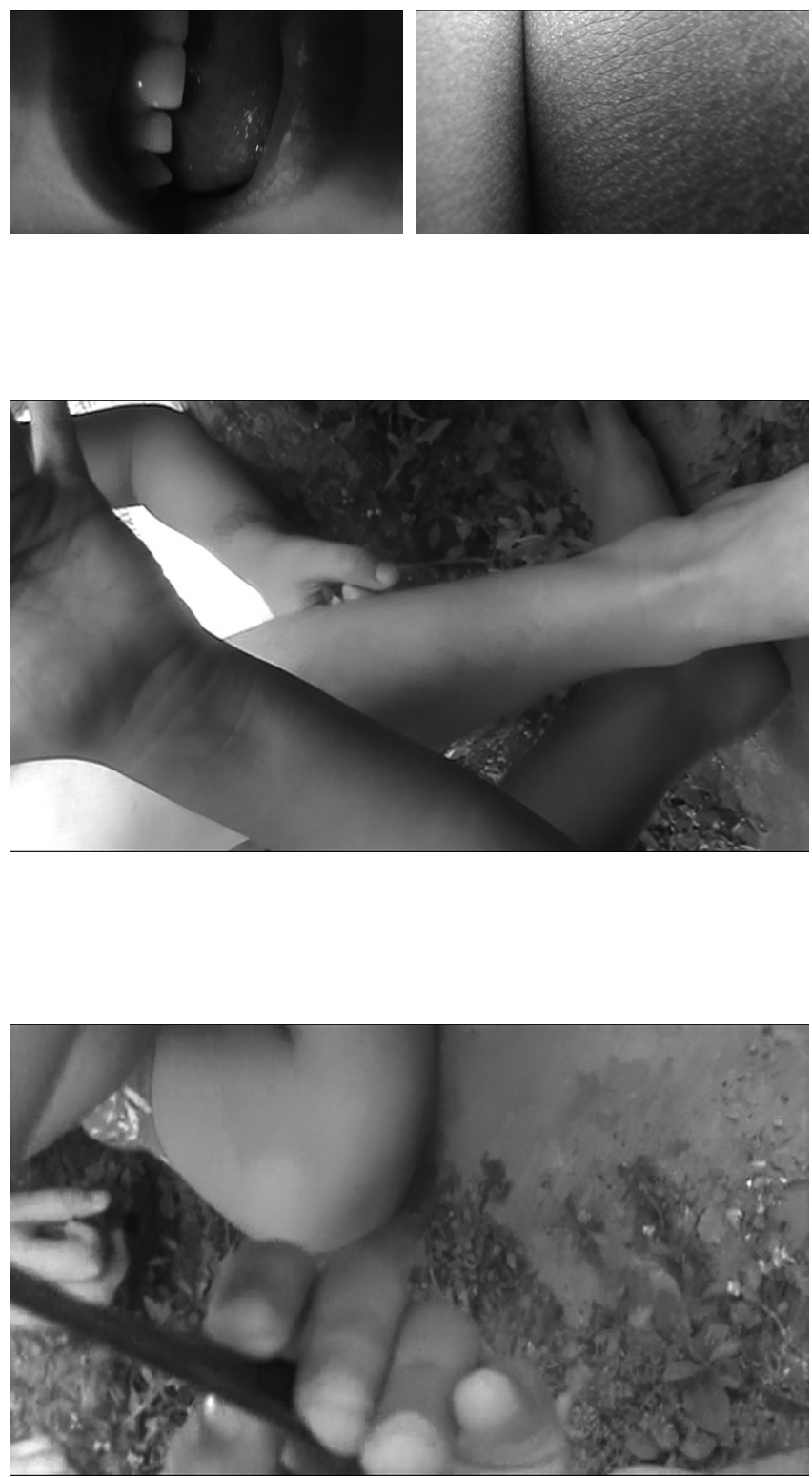


\title{
4 \\ DELÍRIOS IRRACIONAIS DA IMAGINAÇÃO
}

\begin{abstract}
Tá vendo essa trilha de cimento? Eu acho que tem um macaco. Então eu acho que o macaco que fez a trilha. Então eu acho que ele subiu lá no topo daquela árvore. Eu sei de tudo o que ele fez!
\end{abstract}

(Pré I, 2012, $7^{\circ} 23$ )

Terça-feira, 15 de julho de 2014

Oi professora Sonia,

[...] Mas gostaria de aproveitar esse email, esse nosso encontro virtual, para colocar algumas coisas que estão me angustiando no meu trabalho, se puder me ajudar a pensar....

A primeira delas é em relação a matemática mesmo. Quando olho as imagens que as crianças produziram fico pensando que as crianças nos apresentam um mundo que não é representativo, então quando eu olho e digo que vejo uma matemática criança (estou usando o termo sugerido pelo prof. Gallo) é o meu olhar, é a matemática que vejo. Isso seria uma maneira de dar uma identidade? Representar? Eu gosto da matemática criança, gosto do que isso me faz pensar, mas.... 
A segunda parte da sugestão do professor Carrera, o criançando, as crianças estão lá criançando. Com essa ideia do criançando fiquei pensando que poderia ser em torno mesmo do criançando, da experimentação, de uma produção de um modo de vida, de um modo de existência e de um poder da vida..... pensei em compor pensando em um pensamento crianceiro... que seria um pensamento que se experimenta. Fugiria eu assim da representação? Da captura?

Bom estou aqui literalmente empacada com minhas angústias.

Fico no aguardo, ansiosa pelo retorno.

Abraço grande

Bianca

Quarta-feira, 16 de julho de 2014.

Querida Bianca

[...] As questões que você aponta são muito pertinentes e me afetam sobremaneira. O que está acontecendo ali, no movimento de pesquisa, no fazer daquelas crianças? Quando nomeio: "matemática criança” não estou identificando? E se houvesse uma adjetivação, uma dessubstancialização no lugar de uma substancialização, uma nomeação, uma identificação?

E se pensássemos, adjetivando, em um devir criança da matemática?

Gosto de pensar em "devir criança”. A matemática, como forma, como identidade, colocando-se em devir, em um devir criança, o que ela pode desdobrar? Desdobra invenção, pura invenção.

a forma criança tem como fim a forma adulto, uma teleologia.

Uma matemática criança não teria como finalidade a matemática "adulta"? 
[para pensar essa questão veja o texto da Kastrup que eu indiquei na sua qualificação: Virgínia Kastrup, Psicologia: Reflexão e Crítica, 2000, 13(3), pp.373-382]

Devir criança da matemática poderia apontar para um movimento inventivo, que coloca a invenção em movimento a própria invenção. Pura invenção. Puro devir.

A bricolagem, que você traz como movimento de escrita - uma política de escritura? - pode fazer, também, como metodologia... que te parece?

Bem, são só alguns assombros que me atacaram quando li seu trabalho e agora fui provocada por seus pensamentos.

Abusar da tecnologia quando a distância nos acomete pode ser uma possibilidade. O que acha?

$[\ldots]$

Seguimos nesta conversinha ao pé do ouvido

Grata pelas provocações

beijos, com carinho

ah, segue uma dissertação de uma orientanda, a Marina Furtado Terra. ela acabou escrevendo em um tom, digamos, devir criança da escrita. Ela também fez o que poderíamos chamar de bricolagem... o Sílvio Gallo esteve na banca. Ela é da geografia, mas talvez pode interessar.

\section{Tartamática infantil}

[...] A criança $a^{1}$ não tem pensa:

Oolho vê, a lembrança revê, e a imaginação transvê.

1 As palavras em negrito foram substituídas para se adequarem ao contexto. 
É preciso transver o mundo.

Isto seja: homem deu a forma. As crianças deformam.

É preciso desformar o mundo:

Tirar da natureza as naturalidades.

Fazer cavalo verde, por exemplo.

Fazer noiva camponesa voar - como em Chagall.

Agora é só puxar o alarme do silêncio que eu saio por ai a deformar.

(Barros, 2013, p.324)

Mais uma vez o poema Manoelês ajuda a continuar o movimento de pensar a criança, a infância. Parece que com crianças, ou com infância, podemos deformar o mundo, pensar o mundo como algo já estabelecido, algo já pensado, algo já organizado, algo já formado por homens, por homens adultos, as crianças, a infância, podem alterar as formas, podem desconfigurar o já determinado, o já fixado. Podemos ainda dar mobilidade ao mundo, flexibilidade às coisas, ao fazer isso, ao deformar o mundo, outras formas aparecem, outras formas inusitadas e inesperadas.

Podemos tirar as coisas, o mundo de sua fôrma, de sua forma, sair do molde, sair da linha. Parece que com crianças, com infâncias podemos ser outros deformados, outras formas inusitadas e não pensadas, habitantes de não-lugares. Podemos correr riscos, caminhar na corda bamba, serpentear pelos espaços. Podemos nos colocar na infância das coisas com sensações clandestinas, não legalizadas. É o devir-criança, é a infância como possibilidade de pensar o que não se pensa, como abertura ao inusitado que faz surgir na dobra desdobramentos infinitos e inesgotáveis que me convidam a continuar o movimento dessa escrita. Não falarei de maneiras novas para educar, para ensinar, formas modernas, mais eficientes para as crianças aprenderem. Nem mesmo o que as crianças "devem" saber sobre isto ou aquilo em cada idade. Buscarei ascender ao 
tartamudo, como provoca Barros (2013), "[...] Por que não ascender de volta para o tartamudo”, distanciar das modulações, dos protocolos, para buscar na infância, na infância das coisas alguns indícios para pensar em um devir-criança da matemática.

Ascender ao tartamudo para buscar na infância, na infância das coisas, um devir-criança da matemática que cria condições para o brincar, para a inventividade, para as profanações, para os flertes, para os encontros, para as experiências. As filmagens produzidas pelas crianças nos fazem pensar que elas, as crianças, têm uma relação infantil com as coisas, com o mundo que as cercam. Quando falo de infantil não me refiro a uma relação inferior, uma relação de quem não sabe, de uma relação que precisa ser tutelada, muito pelo contrário, e sim uma relação de diferença, de saberes outros.

As produções imagéticas nos apresentam crianças que pensam e experimentam, pensam e experimentam muito o mundo, as coisas, os seres pequenos e desimportantes. É esse pensar e experimentar infantil que as crianças, o devir-criança que me fazem pensar: o que a matemática, como forma, como identidade, colocando-se em devir, em devir-criança pode desdobrar? Ora a organização molar da matemática, sua historicidade, sua estrutura, "sua segmentaridade dura não impede todo um mundo de microperceptos inconscientes, de afectos inconscientes, de segmentações finas, que não captam ou não sentem as mesmas coisas, que se distribuem de outro modo, que operam de outro modo", como afirma Deleuze e Guattari (1996, p.83). É a matemática molecular, um devir-criança da matemática operando fora dos reis e das regências, das regras e convenções, das normas e dos acordos. Ele não se define pelo certo e o errado, pelas certezas dadas e definidas, pelas formas e estruturas, pelas identidades, pela reprodução, mas rompe com a ordem estabelecida, com 
os dogmas, dificulta o reconhecimento, adota o esquecimento para se que entre no movimento de nascimentos sem origem, ou seja, produz nas dobras desdobramentos de invenção, pura invenção.

Vamos achar formiga. Um formigueiro, rápido Raissa, rápido, rápido Thiago

Vai camera ela!

Deixa eu ver!

Não dá! Olha essa aqui, não dá é pequininha.

Ah, tem achar gande.

Olha o que eu achei!

Coloca na camera.

Camera o dedim.

Olha aqui um furmigueiro!

Aqui o formigueiro, era esse aqui óh!

Não toca, mora a formiga, aí uma, aí, óh, óh, óh!!

Uma bebê gente, uma bebezinha. Ah, oh, tá procurando a mamãe.

Uma gande, uma gande.

Tá procurando a outa formiga, oh, que bonitinha!

Olha aqui a mãe, a mãe formiga, aqui as formigas, as formigas aqui!

Tá vendo elas Raissa, tá vendo elas! Gava, gava, gava pra gente vê! [...] (Pré I, 2012, 5²6)

Desse modo, um devir-criança da matemática nos aponta para um movimento inventivo, que coloca a invenção, a própria invenção em movimento, que coloca o pensamento em movimento. Se tomarmos como ideia que o ato de pensar não é inato, nem adquirido, mas deve ser gerado no pensamento por forças externas que fazem o pensamento sair de sua imobilidade, provocando encontros, intercessões, acontecimentos, então, como nos diz Deleuze, (1988, 243) "pensar é criar, não há outra criação, 
mas criar é, antes de tudo, engendrar, "pensar" no pensamento”, inventar, fazer o novo, fazer saltar o impensável, o ainda não-pensado. Assim, um devir-criança da matemática não pensa tudo, não sabe tudo, não determina, não estabelece limites, pois o próprio limite é não ter limites para pensar o mundo, por isso, ele permite a experiência de pensamento, invenção de si e do mundo. Kastrup (1999, p.23) nos diz que

A invenção não opera sob o signo da iluminação súbita, da instantaneidade. A invenção implica uma duração, um trabalho com restos, uma preparação que ocorre no avesso do plano das formas visíveis. Ela é prática de tateio, de experimentação, e nessa experimentação que se dá o choque, mais ou menos inesperado, com a matéria. [...] O resultado é necessariamente imprevisível. A invenção implica tempo. [...] Não é reserva particular de um sujeito nem se confunde com o mundo dos objetos. Ela é a condição mesma do sujeito e do objeto.

Desse modo, a experiência de pensamento não traça percursos, mas funciona como um modo de viagem do pensamento, que se posiciona na escuta atenta do outro, no choque com o encontro a outro pensamento, que está aberta a pensar aquilo que não sabe, aberta a pensar o ainda não pensado, a esperar o inesperável. Vai camera ela! Não dá! Olha essa aqui, não dá é pequininha! Poderia perguntar aqui, como que uma formiga, uma pequena formiga não caberia na lente da câmera? E a conversa segue, Camera o dedim! E o dedo da formiga? É como a Alice (Carroll, 2002, p.18) que pergunta "Para cima ou para baixo?" Em que sentido? As perguntas, tanto minhas quanto de Alice, não têm resposta porque, nos dirá Deleuze (2011, p.79), "é próprio do sentido não ter direção, não ter 'bom sentido”, . É próprio das crianças produzirem sentidos muitas vezes 
sem sentido para o adulto. É como se ao mesmo tempo a formiga e seu "dedim" fossem e não fossem alcançados pelo ângulo de visão das crianças observadoras. Mas ao mesmo tempo as crianças buscam um ângulo, não está definido o ângulo, mas há um intenso movimento angular de busca. Posso pensar também, que nesse momento, nem a formiga, nem seu dedinho, caberiam na lente, no foco da câmera, pois a conversa, a potência do pensamento disparado não caberia em nenhum lugar, muito menos sob o foco de uma filmadora.

As crianças pensam o que não esperamos que elas pensem, pois, esperamos que elas pensem de determinadas maneiras, a partir de uma lógica instrutora, formadora, limitadora, unívoca. Para Kohan (2005, p.224)

O pensar não está dado. Ele nasce, se gera, se produz, a partir do encontro contingente com aquilo que nos força a pensar, aquilo que instala a necessidade absoluta de um ato de pensar, de uma paixão de pensar.

Então parece que, pensar o não-pensável, seria encontrar o que não se pode ou não se deve encontrar, o impossível de encontrar. Talvez por isso, adultos pasmem diante dos encontros, das descobertas e dos pensamentos infantis. As crianças não esperam para pensar, nem precisam de liberação, aprovação ou ordenação para isso. Seria um pensar que não segue uma direção, um pensar não linear, fora do tempo linear. Não precisa de chave para abrir, nem manivela para iniciar o movimento. Para Deleuze (1987, p.96)

Pensar depende necessariamente das forças que se apoderam do pensamento. O que nos força a pensar é o signo. O signo é objeto de um encontro; mas é precisamente a contingência do encontro que garante a necessidade daquilo que 
ele faz pensar. $\mathrm{O}$ ato de pensar não decorre de uma simples possibilidade natural; ele é, ao contrário, a única criação verdadeira. A criação é a gênese do ato de pensar no próprio pensamento.

Por isso, o pensar acontece agora, com uma intensidade imensurável, em um tempo kaiônico, como não há espera, como não existe deixar para depois, o pensar é acontecimento saturado de agoras intensos, não numeráveis, nem sucessivos. Esse tempo do pensar é um tempo generoso, um tempo mais estendido, pois é o tempo do acontecimento e da invenção. Somente um devir-criança da matemática poderia pensar o não pensável. Somente alguém sem idade, nos dirá Kohan (2005, p.149) "fora do tempo linear, alguém que não sabe não se pode esperar o que, aparentemente, não se pode esperar, ou quem sabe, alguém que não crê que não se pode esperar o que, todos dizem, não se pode esperar; ou alguém que simplesmente, não está convencido dos "não se pode", "não é possível" ou "não se deve". Neste sentido, surgem alguns indícios de uma "didática da invenção" (Barros, 2013), que para "apalpar” um devir-criança da matemática é preciso saber:

Se rodá fica rodando o céu;

O modo que o macaco faz uma trilha de cimento para chegar ao topo da árvore;

Como pegar o sol pelo rabo;

Que um monte de pedrinhas carrega mais enormidade de encantamento que uma pedreira;

Por queé que chegamos de ida quando nem partimos de volta; Qual o lado do tempo que corre primeiro.

Que o dedim da formiga cabe nos olhos da camera, mas não a formiga.

Etc.

Desinventar objetos; 
Repetir, repetir, até ficar diferente;

Partir sempre do descomeço;

Mudar a função das coisas

“Desaprender oito horas por dia”. (Barros, 2013, p.275)

Parece ainda que um devir-criança da matemática acontece no encontro com o corpo, com outros corpos. Corpos que são movidos pela paixão, e não pela razão, por isso, elas relacionam-se melhor no ver, no ouvir, no pegar, no provar, no cheirar. É nesse encontro de corpos, encontros de pensamentos que as crianças, a infância descortinam e descobrem o mundo, partilham um sensível, partilham-se no sensível. Dessa maneira, Rancière (2009, p.15) pondera "uma partilha do sensível fixa, portanto, ao mesmo tempo, um comum partilhado e partes exclusivas. Essa repartição de partes e dos lugares se funda numa partilha de espaços, tempos e tipos de atividades que determina propriamente a maneira como um comum se presta à participação e como uns e outros tomam parte dessa partilha”. Trata-se então da ideia de um devir-criança da matemática partilhado pela multidão criança (Abramovicz; Levcovitz; Rodrigues, 2009), que abre a possibilidade de novas vivências, novas experiências, novas disposições não consensuais, sempre parciais e totalmente provisórias e lampejosas.

Partilhar um sensível talvez tenha muito a ver com resistência. São corpos, pensamentos que se encontram sem rumo, sem direção, fragmentados, abertos a qualquer coisa na qual não haja hierarquização que, por meio de uma seleção diz que as coisas pertencem ou não pertencem a, ou ainda resistentes a determinações de relação e separação entre formas. Esse sensível se compõe em uma zona de vizinhança não localizável, que nos arrasta a pontos indiscerníveis, sendo ainda habitado por uma potência de pensar, de inventar, de afectar-se. 
As produções imagéticas das crianças apresentam um devir-criança da matemática que não se preocupa em nomear, categorizar e generalizar o mundo, mas atua na ordem de desnomear, descategorizar, desgeneralizar o mundo, as coisas, os seres. Ainda, fugitivo, estrangeiro, sorrateiro, vivente e sobrevivente da clandestinidade, pois esquiva-se, escapa às certezas científicas, escapa às vias certas legitimadas pela ciência, pois como diz Barros (2013, p.): "A ciência pode classificar e nomear os órgãos de um sabiá, mas não pode medir seus encantos”. Um devir-criança da matemática lembra o espírito criança da célebre passagem de As três metamorfoses, em Assim falou Zaratustra (Nietzsche, 2011, p.28-29). Uma criança é "um novo começo, um jogo, uma roda a girar por si mesma, um primeiro movimento, um sagrado dizer-sim”. A criança nietzscheana não age com comparação ao que já existe, e sim se move para longe das absolutas verdades, da escravidão do pensamento, da cega obediência. Percorre caminhos ziguezagueando, saltando sem se deter em nenhum deles em um movimento a-histórico, intemporal e involutivo.

Ele já é liberdade de pensamento, já é livre das amarras, dos aprisionamentos, dos protocolos, nem mesmo os conhecem, até mesmo os ignoram. Não desobedece às leis, às normas, nem as obedece, não é crença, nem descrença. Mas é pura confiança, é um sagrado sim à existência ao mundo, à vida, aos seres. Por isso, é aventureiro, é receptivo, é abertura à existência à vida e a tudo o que nela há e contém. É destemido, adentra no desconhecido por caminhos não trilhados e conquista seu próprio mundo. Um mundo sem limites, sem instruções, sem regras embrutecidas, cristalizadas, pensa o mundo, os seres, as coisas como se fosse a primeira vez. Há um olhar cheio de ansiedade pelo mistério, pelo começo, por que não, de deslumbramento, um olhar inaugural, inaugurador de um pensar que não tem princípios pensáveis. 
Kamilly vem cá, olha aqui vou espalhar, olha aqui Kamilly, olha aqui, vem cá vê.

Deixa eu vê.

Rápido. Nicole - aproxima bem a câmera da areia. KAMILLY, KAMILLY, não é terra, olha não é terra, olha é pedra, um montão de pedrinhas! Olha aqui comigo. Tudo isso aqui é pedrinhas! - (Pré I, 2012, 6º 8)

Elucubrar pedantemente sobre a fabricação de objetos - material educativo, brinquedos ou livros - que fossem apropriados para crianças é tolice. Desde o Iluminismo essa é uma das mais bolorentas especulações dos pedagogos. Seu enrabichamento pela psicologia impede-os de reconhecer que a Terra está repleta dos mais incomparáveis objetos de atenção e exercício infantis. E dos mais apropriados. Ou seja, as crianças são inclinadas de modo especial a procurar todo e qualquer lugar de trabalho onde visivelmente transcorre a atividade sobre as coisas. Sentem-se irresistivelmente atraídas pelo resíduo que surge na construção, no trabalho de jardinagem ou doméstico. Em produtos residuais reconhecem o rosto que o mundo das coisas volta exatamente para elas, e para elas unicamente. (Benjamin, 1987, p.16)

O encontro com as crianças, com a infância, com as produções imagéticas infantis convida a pensar com elas, e quem sabe, além delas. As crianças não se lançam na aventura da procura com um plano previamente estabelecido, com uma rota previamente traçada. Parece que as crianças são dadas a encontros, e somente depois, quem sabe, realizam seus achados. Elas indicam e oferecem algumas possibilidades para pensar que alguns encontros, quem sabe, são inerentes a um devir-criança da matemática. $\mathrm{O}$ primeiro encontro é o próprio encontro entre os corpos, os corpos-crianças, os corpos-seres, o corpo-câmera. O encontro, a junção, a aproximação dos corpos, suas 
núpcias funcionam como um disparador, um provocador, uma violência ao pensamento e impulsionam a descoberta. Nesses encontros, nessas núpcias as crianças encontram possibilidades infinitas de pensar, inventar, criar o mundo. Pensamentos gerados com o corpo, pelo corpo, grudados, espalhados em todas as extensões dos corpos. Pensamentos sem imagens, pensamentos destituídos de pressupostos. As produções imagéticas das crianças nos apresentam que nesses encontros não há seres solitários, pois mesmo sozinhos uma multidão nos habita. Então, não há encontros se estivermos "sozinhos", é preciso sempre do outro para acontecer os encontros.

O segundo encontro diz respeito à afectação, ou seja, é um encontro que atravessa os sentidos, os afetos, a percepção. Há um vínculo estabelecido na extensão do encontro dos corpos. As sensações da ante-descoberta, da descoberta é sentida na pele, no pelo, no contrapelo, atravessa a derme, a epiderme. Atravessam todos os órgãos, todas as funções, todas as partículas, todas as moléculas, todo corpo, todos corpos como flecha. Os afectos, as sensações, os sentimentos, nos diz Deleuze e Guattari (1992, p.213) "transbordam a força daqueles que são atravessados por eles". Poderia dizer mais, com a ajuda deles, que a criança é mostradora de afectos, inventora de afectos, criadora de afectos. Não é somente em sua relação com o mundo que ela os cria, ela "os dá para nós, e nos faz transformar-nos com ela, ela nos acompanha no composto”. O devir-criança, o devir-criança da matemática é um "ser de sensação, e nada mais: ela existe em si”.

Isso faz pensar no terceiro encontro, a liberdade do olhar. O aqui olhar não é um privilégio exclusivo do olho, mas de todo o corpo, de todos os corpos; corpos que se olham e se enamoram. O olhar é um olhar desnudado, atento, liberto das engessaduras, um olhar que indica sempre nascimento, um olhar aberto ao mundo, 
sensível e por que não dizer, um olhar poético. De acordo com Leite (2011, p.103) "a criança abre um devir que não é senão espaço de uma liberdade sem garantias, de uma liberdade que não se sustenta sobre nada, de uma liberdade trágica, de uma liberdade que não pertence à história mas que inaugura um novo começo, de uma liberdade libertada". Eu adulta vejo a areia e ela não produz em mim, aparentemente, nenhum afeto, nenhuma mobilização. Mas as crianças descobrem, que, o que eu, adulta, chamo de areia, "são pedrinhas, um monte de pedrinhas". É um olhar despudorado de perspectivas, de parâmetros, de visões, de conceitos, de julgamentos. É um olhar de intimidade, um olhar de proximidade, de amizade, pois Kohan (2007, p.127-128) no diz "não há pensamento novo, infantil sem amizade. [...] a amizade está no início do encontro com o outro, no pensamento que os atravessará”. Uma proximidade tal que não é possível representá-la, interpretá-la ou mesmo subjetivá-la, mas um deslocamento, um movimento de des-subjetivação, no qual a existência é atravessada por um com-sentir, por uma intensidade, por uma potência que força a pensar. Não é a amizade com um outro eu unidos por afinidades ou mesmo filiações, mas um tornar-se outro do mesmo, ou ainda, como aponta Agamben (2009, p.92), trata-se de uma amizade "como com-sentimento do puro fato de ser". É essa experiência de amizade que nos arrasta à transgressão, ao desconhecido, à invenção de novas possibilidades de vida, à partilha, a partilha do sensível.

Esse olhar de intimidade, de amizade impulsiona o próximo encontro - a urgência do encontro, a urgência do acontecimento, a urgência do pensar. Parece que se não for agora, já, neste instante, o encontro - e toda sua potência - diluirá no ar, evaporará na água. É como se o encantamento, a mágica durasse um milésimo de segundo, ou menos que isso, ele não se repetirá, porque ele é único, 
por isso a urgência, ele pode escapar e no próximo instante já não será mais o mesmo acontecimento. Por isso, cada olhar é sempre o primeiro, cada toque é sempre o primeiro, a primazia do gesto, do cheiro, o conhecimento primeiro nascido do sensível, o olhar de fonte. Então, posso ouvir as crianças dizendo, vou depressa, vou correndo, vou na toda, vou agora, porque eu tenho, muita pressa, muita pressa, muita pressa... Essa urgência se compõe de velocidades, nas quais as crianças não param de atravessar devires, por isso, não grudam, não capturam, não fixam, mas deslizam, lampejam, e são dadas ao esquecimento temporário de si mesmas, das palavras de ordem, dos aprisionamentos.

Diante desses encontros, que as crianças, a infância, as produções imagéticas permitem, posso dizer que, um devir-criança da matemática habita os encontros, encontros dos corpos - crianças, seres, natureza, coisas outras, outras coisas, por isso não acontece "sozinho". Faz morada nos vínculos estabelecidos e nos afetos disparados, são sensoriais. Lança-se de um olhar sensível, transvisto, um olhar que atravessa o mundo. Um olhar desprendido da utilidade, da finalidade, do regramento dos sentidos. Se potencializa na urgência e na emergência de destelhar o mundo, as nações, as fronteiras.

\section{Infanciomática inquietante}

Gente já sei vamos fazer de grupo em grupo.

Ah, não! Vamos fazer assim desse jeito.

Vamos fazer uma roda, uma roda, roda.

Não!

Assim, trenzinho!

Eu dirigia.

Hein, eu queria dirigi. 
Vamo.

Brïmmmm, aummmm,

Hein, o trem é aqui.

Hein, quem vai pra estação?

Quem vai descer em Cerejeira?

Quem vai descer em Cacoal?

Eu não!

Ô João Vitor, você vai descer em Cacoal?

Quem vai descer em Cuiabá?

É assim os vago do trem! É Assim!

Você vai descer aonde?

Em lugar nenhum.

Eu não vou descer.

Você vai pra que cidade?

Pra lugar nenhum.

Não pode dentro do ônibus, você vai morrer, o ônibus tá andando.

Entra em outro trem!

Eu já cheguei de volta.

Vai que o ônibus vai andar.

Eu vou parar lá em Ji-Paraná.

Eu vou pra Porto Velho.

Então vai com ela porque ela vai pra Porto Velho.

Eu vou dirigindo.

Você vai dirigindo pra levar o trem pra Porto Velho.

Pare o ônibus! Pare o ônibus! (Pré II, 2012, 129 9)

Assim, como as produções imagéticas das crianças me indicam algumas possibilidades para pensar, quem sabe, alguns encontros que são inerentes a um devir-criança da matemática, também me dão algumas pistas para pensar em seu caráter infantil. A primeira delas pode ser expressa como uma relação "de experimentação mais próxima com o meio molecular”, como aponta Kastrup (2000, p.378). As imagens produzidas apresentam crianças que 
experimentam, se experimentam e se deixam experimentar, exploram o mundo, os seres as coisas. Neste sentido Deleuze (1997, p.83) diz que, "A criança não para de dizer o que faz ou tenta fazer: explora os meios, por trajetos dinâmicos, e traçar o mapa correspondente".

Quem quer brincá de dança da cadeira?

Só uma!

Aqui oh!

Aí não!

Aí tem espaço!

Aí tranca o lugar!

Quem quer brincá de dança da cadeira?

Agora você vai sentá aqui e registrar a gente.

Filha já pra casa!

To brincando com minhas amigas.

Vai pra casa que tá na hora de você chegar em casa.

To brincando com minhas amigas, depois eu vo pra casa, minha mamãe!

Hein, tem nove cadeiras.

Um, dois, três, quatro, cinco, seis, sete, oito, nove, dez, tem dez!

Vem pessoal.

Deixa eu ver uma coisa aqui, deixa eu vê se dá para registrar todas as cadeiras.

Não, né!

Percorre as cadeiras focando com a câmera.

Como é que registra isso?

Deixa eu vê de novo.

E de longe, dá pra ver todas as cadeiras?

Distancia e percorre novamente as cadeiras focando com a câmera

Do mesmo jeito dá! (Pré II, 2012, 129) 
Um devir-criança da matemática acontece na experiência, na infância do mundo, na infância das coisas, pois é na infância que experienciamos a vida, experienciamos o mundo e experimentamos distanciados das amarras da razão, afastados dos aprisionamentos, das certezas. Nasce na abertura, no desconhecido, na imprevisibilidade, na incerteza, no descontrole, foge dos modelos, dos dispositivos que querem normatizar e regulamentar sua existência. É povoado de desejos, das necessidades da imaginação e da paixão. Agamben (2005, p.25) nos dirá “[...] a experiência não é mais que uma vassoura desmantelada, um proceder tateante como o de quem perambulasse à noite na esperança de atinar com a estrada certa".

A conversa entre três meninas chama a atenção quando uma delas pergunta para as demais: "quanto é zero mais zero?” Ela faz o sinal do número dois no ar com o dedo, bastante séria. As colegas demoram cerca de alguns segundos para responderem, por isso, ela não as espera e mesmo responde: "um zero mais outro zero é dois zeros," (pré-escola II, 04/10/2012). Poderia dizer, inspirada em Manoel de Barros (2013, p.441), que as crianças desescrevem a matemática molar, arrombam as normas, as regras, as técnicas, por que não, a gramática matemática, "ao falarem absurdez, abortam o bom senso". Elas não sabem, por exemplo, que o zero é um elemento neutro na adição. Então, as crianças inventam e mudam a função do zero, mudam a função zero das coisas, porque elas povoam o vazio, e com isso o "zero delira”. Um devir-criança da matemática se compõe com os restos da matemática escolar e não em oposição a ela, distanciando-se da matemática de tanque que esta estagnada, estanque e podem até mofar. Isso é possível? Alice ao ouvir essas coisas diria: "Não posso acreditar nisso! Não se pode acreditar em coisas impossíveis!” Contudo a Rainha de Copas responderia "Tente, tente de novo, pratique algumas vezes por dia, 
sempre praticava meia hora por dia, algumas vezes cheguei a acreditar em até seis coisas impossíveis antes do café da manhã" (Carroll, p.2002, 192).

A segunda pista diz respeito a um movimento temporal. Movimento esse que indica um tempo, ou tempos distantes do tempo numerado, sucessivo, orientado. Esse tempo que povoa um devir-criança da matemática é o tempo kaiônico, ${ }^{2}$ Kairós e Aiôn juntos movendo-se pelas situações, atentos às ocasiões. Esse tempo não se define por uma linha contínua de movimentos sucessivos, mas acontece num movimento circular de repouso, lentidão e velocidades repleto de intensidades. É um tempo infantil, que enquanto Cronos segue os números, Kaiôn ${ }^{3}$ brinca com eles. É ainda um acaso, uma oportunidade, um acontecimento, lampejoso como um raio que prenuncia algo de inesperado, de imprevisível. Ele não pode ser medido, nem especificado, muito menos definido, não reflete o passado, nem antecipa o futuro. É um tempo indefinido, é o melhor no instante presente, é a própria suspensão do tempo. Não é regular, nem homogêneo, nem pertence ao mundo dos relógios, das ampulhetas, ou a qualquer outro instrumento de medida tempo. É multiplicidade em movimento intenso, uma força infantil, desigual, sublime ocasião, que só aparece desaparecendo.

Enquanto Kairós "faz aparecer a solução como algo brusco, brutal e revolucionário” (Deleuze, 1988, p.182), Aiôn, tempo indefinido do acontecimento só "conhece velocidades e ao mesmo tempo não para de dividir o que acontece num já-aí e um ainda-não-aí, um tarde-de-mais e um cedo-demais simultâneos, um algo que ao mesmo tempo vai se passar e acaba de se passar" (Deleuze; Guattari, 1997, p.51). Juntos, esse tempo

2 Combinação das palavras Kairós e Aiôn.

3 Combinação das palavras Kairós e Aiôn. 
kaiônico movimenta-se em todos os sentidos, ao mesmo tempo, sem nunca se deterem, sempre se desviando do presente. Vai de trem, vai de ônibus, para Cacoal, para Cerejeira, Porto Velho, Ji-Paraná..., ao mesmo tempo, em todos os tempos, para todos os lugares, de todas as maneiras, no mesmo instante, no mesmo lance, em todas as direções, em todos os sentidos. Um tempo penetrando o outro, coexistindo com ele em todas as temporalidades. Misturados, embolados, rizomados, Como isso é possível? Como é possível movimentar-se sem sair do lugar, sem temporalizar as idas, vindas e voltas? Como é possível habitar sem fixar? Um devir-criança da matemática é uma criança crianceira; criançando ela reina em Kaiôn, tempo da criação, da invenção.

Eu sou do pré I, olha aqui meu tamanho passa de você!

Eu já to grande igual a você!

Olha aqui onde você pega, pega aqui, não é aqui.

Então, as produções imagéticas das crianças levam a pensar em tempos, outros tempos. Tempos, que sendo outros, não estão vinculados à linearidade, mensurabilidade, ao tempo cronológico, no qual estão presentes nas práticas educativas, no currículo, e em todas as ideias que norteiam o que as crianças devem saber e aprender em qual faixa etária, em qual estágio da vida. As imagens produzidas pelas crianças, imagens trêmulas, embaçadas, rápidas, curtas, desfocadas, paradas, em movimento nos convidam a pensar no tempo kaiônico, no tempo oportuno, acontecimento, experiência. Ou seja, o que as crianças devem aprender e saber dentro de um tempo cronológico está lá estabelecido, previsto e sendo cumprido. Entretanto, as crianças atravessam esse tempo, esse "conteúdo", esses saberes, essas práticas e escapam às modulações ou aos clichês presentes nos ditos e não ditos e nos modos de 
senti-las, de percebê-las, de pensá-las. Por isso, o tempo do devir-criança da matemática é um tempo fora do tempo histórico, um tempo sem marcação, sem começo, nem fim, nem linearidade. É tempo do imprevisto, do ainda não pensado, do incontrolável, do incalculável.

As imagens produzidas pelas crianças apresentam outra pista para pensar o movimento de um devir-criança da matemática: a profanação da ritualização. Neste caso, o jogo é um indício de profanação daquilo que com o tempo se sacraliza, adquire forma, permanência e generalidade. Para Agamben (2005, p.89) "Enquanto o rito transforma eventos em estruturas, o jogo transforma estruturas em evento". As crianças celebram os ritos, manipulam objetos e palavras sagradas, porém, esquecem, ou mesmo desconhecem o sentido e o escopo, como ainda aponta Agamben. É o jogo, é a brincadeira que nos tira da esfera do sagrado, da ritualização e devolve ao livre uso o que está consagrado. Nesse movimento, o uso dos objetos, dos espaços, dos lugares, do mundo, dos seres, das coisas; além de livre é negligente, distraído, desabusado e desautorizado.

Cabe pensar aqui nos movimentos do jogo, da brincadeira, movimentos esses que lembram o mover-se de um dançarino de pés leves, envolvente, sedutor, encantador que cria e inventa sempre inesperadamente um novo jogo de sedução. Envolvidos pela dança, pela mobilidade, pelo deslocamento põe a prova o mundo, os seres as coisas, desarmando-os de toda fixidez, pondo-os a dançar guiados por um caminho cujo fim é desconhecido. Um devir-criança da matemática é acaso que seduz e é seduzido, por isso, quer apenas dançar com os pés do acaso, como nos dirá Zaratustra (Nietzsche, 2011, p.232) "Deixai vir a mim o acaso; ele é inocente como uma criança”. É nesse jogo, nessa brincadeira dançante que esquecemos a prisão, que fazemos tremer tudo quanto é fixo. Um 
devir-criança da matemática joga, brinca, profana, dança como se flutuasse ou pairasse no ar, ele é livre da amarras porque seus pés são leves. Ele coloca para dançar o corpo e no mesmo movimento, por contaminação, todo pensamento aprisionado por regras embrutecidas.

As produções imagéticas apresentam crianças que profanam o tempo todo, todo o tempo. Elas profanam o tempo escolar, tempo tipicamente cronológico, sucessivo, introduzindo o tempo kaiônico, intensivo e instantâneo e ocasional. Profanam o tempo a ser "utilizado", o que deve ser feito, quem elas devem ser (alunas e não crianças, mãe, filha, bicho...), os objetos, os modelos dados, o currículo escolar, os lugares habitados, profanam... Então, me parece que um devir-criança da matemática também profana, e assim, não segue modelos, não segue ordenação, nem regras previamente estabelecidas, foge dos modelos ideológicos prontos, do imobilismo e da estagnação; é uma criança livre de amarras. Não espera para ser sentido e experienciado.

Oh! O número da minha casa, da minha casa, se vocês querer ir na minha casa, na minha casa, o número da minha casa é seis, cinco, dois, seis. Daí vocês já vira para minha casa, daí minha mãe ta lá pra receber vocês. (Pré I, 2012, 10²1)

As produções imagéticas das crianças apresentam situações em que um devir-criança da matemática profanadora acontece. Parece que no enredo acima, o número é usado como orientador, direcionador, localizador. Ele aparece para identificar, localizar a casa, indicar, dar rumo ao caminho, ele aparece para disparar, experienciar a potência do encontro, e esse encontro, é provisório, passa como um lampejo, seja para a própria criança, seja para as outras crianças que são afetadas pelo encontro.

Aqui as crianças profanam o currículo escolar, o conteúdo curricular limitado aos números (de zero a dez) 
como representação simbólica que são submetidas, elas usam desabusadamente e desautorizadamente os saberes. As crianças fogem do currículo que cria ordem reguladora de suas subjetividades, fogem das representações, não porque elas as conhecem, mas porque as ignoram. A representação está no lugar de, no lugar da coisa, e revela uma única verdade, dita palavras de ordem, e toda palavra de ordem, aprisiona, ou seja, a representação homogeneíza o pensamento, dita condutas e saberes; cria um perfil, uma identidade, um papel e isso faz reproduzir um modelo. Um devir-criança da matemática não é representativo, não habita o campo da representação, mas entra no campo das sensações, por isso opera com o pensamento de modo que faz gerar essa coisa mais lúdica, fantasiosa, imaginativa, inventiva, sensitiva.

Podemos pensar aqui na ideia de algo que é sagrado (currículo e aula) que pode ser profanado, quando, por exemplo, as crianças no meio da aula brincam com um jogo de sequência e deixam de lado a aula, ou quando durante a explicação de uma atividade, uma das crianças orienta as demais a chegarem a sua casa, ou ainda durante o momento do lanche, hora de ficarem em silêncio, as crianças explicitam suas conjecturas. Nessas ocasiões, elas tornam o jogo divino no momento de aprendizagem pela experiência. Com isso, rompem com o embrutecimento das formas de conhecimento que atuam na vida, rompem com o embrutecimento das formas de conhecimento que atuam no âmbito escolar.

Um devir-criança da matemática movimenta-se na aprendizagem pela experiência, como diz Larrosa (2002, p.28), "na prova e pela prova, com a toda a incerteza que isso implica”, por isso, ela não tem limites e nem sequência para acontecer, foge dos artefatos técnicos, da inflação de conhecimentos objetivos, não é e nem tem verdades absolutas, pelo contrário, ela obedece a desordem. Leite 
(2011, p.161) diz que a experiência "[...] não prescreve verdades, e nem pode ser prescrita por outras verdades que a antecederam, ela sempre cria espaços de incertezas, embora também tenha achados".

Eu sei, eu sei contar número em inglês, você não sabe falar assim, uon, thil, three, for, vaive, six, eith, nei, teem, isto que é inglês. Eu também sei.

Então fala.

Como você falou mesmo? Assim, como que você falou mesmo?

Uon, thil, three, for, vaive, ix, seven, eith, nai, teem.

Isso aqui também é inglês uai, thau, teem, o que mais?

(Pré I, 2012, 4 18)

Um devir-criança da matemática não se prende ao acúmulo de informação, não esta preso ao âmbito estritamente objetivo da realidade, não está preso às explicações concretas, objetivas, mas sim é movido pela vontade, pelo desejo, pelo prazer de brincar, de adivinhar, de divinare, como diz Barros (2013, p.316), "quem acumula muita informação perde o condão de adivinhar: divinare”. Por isso, não é informação, nem acumulação progressiva de verdades, ou como diz Larrosa (2002, p.21) "a informação é quase que uma antiexperiência”, ela é quase o contrário da experiência”. Ou seja, a matemática escolar vem carregada de informação e dificulta as possibilidades das crianças experienciarem, movimentarem em devires. Depois de uma aula em que, por exemplo, um número é "mostrado", "informado", em que as crianças contam, pintam a quantidade numérica representativa, posso dizer, ajudada por Larrosa (2002, p.22), que as crianças sabem um número, uma representação numérica que não sabia antes, que elas tem mais informação sobre o ou do número, mas, "ao mesmo tempo podemos dizer que nada 
as tocou, nada as aconteceu, que com tudo o que elas aprenderam nada as sucedeu ou as aconteceu". Assim, um devir-criança da matemática não perde a "varinha mágica" que transforma o real, não perde o mistério, não perde o segredo do que não se explica por meio da informação, da notícia, do dado objetivo.

Um devir-criança da matemática provoca a pensar em uma matemática lesma. Parece que as crianças farejam os rastros deixados pela matemática lesma, aquela que gruda, que deixa sua gosma por onde passa, aquela que se arrasta sobre as superfícies, imprimindo-lhes sua marca por meio de um muco, de uma meleca luminescente. A matemática lesma esfrega a barriga nas coisas, está sempre grudada nas coisas, no corpo e no mundo. As crianças, mesmo sem procurar, esbarram na matemática lesma, encontram a matemática lesma, se interessam pela matemática lesma, pois ela privilegia o corpo, o tato, o toque, o contato, ela cola, ela adere, por isso ela provoca o pensamento, produz pensamento, e parece ser este o projeto da matemática. As filmagens produzidas nos apresentam o tempo todo crianças sendo tocadas, afetadas, mexidas, melecadas pela matemática lesma. Elas, as crianças, confrontam ideias, argumentam, tomam decisões, refutam hipóteses, expões ideias, escutam as outras, antecipam resultados, buscam dados para resolver situações, comunicam-se, pensam e, sobretudo, dão sentido ao que são e ao que as acontecem.

Se no tranco do vento a lesma treme, no que sou de parede a mesma prega; se no fundo da concha a lesma freme, aos refolhos da carne ela se agrega; se nas abas da noite a lesma treva, no que em mim jaz de escuro ela se trava; se no seio da náusea a lesma gosma, no que sofro de musgo a cuja lasma; 
se no finco da folha a lesma escuma, nas calçadas do poema a vaca empluma! (Barros, 2013, p.201)

Parece ainda que a matemática lesma é habitada por lugares, percorre lugares distantes dos cadernos e da lousa e vai abrindo caminho para a experiência. Diferente do caracol, que é uma casa que anda, como poetisa Barros (2013, p.345), “a lesma é um ser que reside”. Por isso, a matemática lesma deixa resíduos nas brincadeiras das crianças quando percorrem caminhos, sem saber muito bem para onde vão, quando arrumam as cadeiras, nas decisões, tomadas, no focado, no achado, nas experimentações, nas descobertas, na perscrutação de realidades improváveis. Ou ainda nas confabulações referente aos seres pequenos, aos seres do chão, às coisas do espaço, na criação de teorias em relação ao tempo, ao céu, às árvores, às trilhas "deixadas pelo macaco". Elas ainda inventam suas próprias maneiras de medir, escolhem em que língua querem falar, estabelecem os percursos, traçam um mapa de seus trajetos. Bem como, nos despropósitos, nos delírios irracionais da imaginação; no encontro dos corpos: corpo-criança, corpo-folha, corpo-cadeira, corpo-bicho. As crianças são contaminadas pela matemática lesma, uma matemática inventiva, brincativa, sem função explicativa, descritiva, padronizativa.

O corpo é o lugar onde a criança conhece a si e os outros, ao mesmo tempo em que, inventa a si e outros. Ela explora a sensualidade e a intimidade corpórea dos seres tocando-os e deixando ser tocada. Ajudada por Bachelard (1991, p.20), poderia dizer que, o corpo é dotado "do ato de nos tocar. Ele nos toca assim como o tocamos, dura ou suavemente". Assim, pensar resulta do encontro de um verdadeiro corpo a corpo, no qual o toque, o contato é dotado de uma alegria, de devaneios, de delírios inventivos e inaugurais, que dão vida aos diferentes modos de ser e de existir. 
A comunhão, as núpcias entre os corpos perturbam nossos sentidos e faz gerar uma percepção mais íntima do mundo, fazendo-nos atear aos detalhes que nos cercam: cores, sabores, odores, olhares, toques, texturas, sons. Não é somente o tato que sente, os olhos que vê, o ouvido que ouve, a boca que sente paladar. Mas todos os sentidos confluindo para pensarmos; pensando tornamo-nos outros, tornamo-nos mundo. Ajudada por Bachelard (1998, p.49) diria "as coisas não são o que são, são o que se tornam. Tornam-se, em nosso devaneio," em nossos intermináveis delírios. Pensar a água é escoar-se, é dissolver-se, é morrer. Pensar o fogo é sentir-se, tornar-se chama, impulso, brilho. Pensar o mundo é tornar-se chão, céu, sol, folha, a filha da formiga, é entrar na trilha do macaco, e quem sabe, ser conduzido com ele a expedições indefinidas, labirínticas, sem saber muito bem onde vai chegar, ou se vai chegar.

Dessa maneira, as imagens infantis nos apresentam um devir-criança da matemática que escapa às modulações, as respostas certas, as verdades absolutas. Escapa aos modos reguladores de ser e de se pensar, escapa às modulações de tempo, de espaços e de corpos. Elas vivem e convivem com a matemática presente no currículo, no tempo organizado, mas os ignoram, às vezes parece que nem os percebem, às vezes fazem até pouco caso desse currículo pré-estabelecido, desse tempo organizado, das atividades programadas. Elas, as crianças, se organizam entre si, em "reuniões", em "assembleias", em concílios, para confabularem a vida, os seres, as coisas, o mundo. Entre iguais elas agem sem controle do adulto, sem tomar emprestado as ideias e as ações do adulto. Nessa relação, entre iguais, elas pensam, produzem, criam, inventam, experimentam o mundo. Elas produzem novas palavras, novos pensamentos, mobilizam e provocam mudanças em si mesmas e nos outros, é o encontro entre pensamentos, 
com o pensamento da outra, com outro pensamento. Esses encontros entre crianças nos apresentam uma explosão da potência do pensamento infantil.

As crianças são atravessadas por um devir-criança da matemática que circula na vida, no mundo, na escola e lidam de outra maneira com ela, por estarem em um eterno movimento de travessias entre fronteiras. $\mathrm{O}$ movimento da experiência primeira, da experiência de fonte, da imaginação, da criação, da invenção. São atravessadas pela incompletude do mundo, pelos saberes primeiros, até mesmos pelos não saberes, pelas descobertas, pelos encontros, pelos achados, pelos acontecimentos. Entram em um tempo, em um espaço, em corpos, onde as horas correm como faíscas e a eternidade é como um verdadeiro presente.
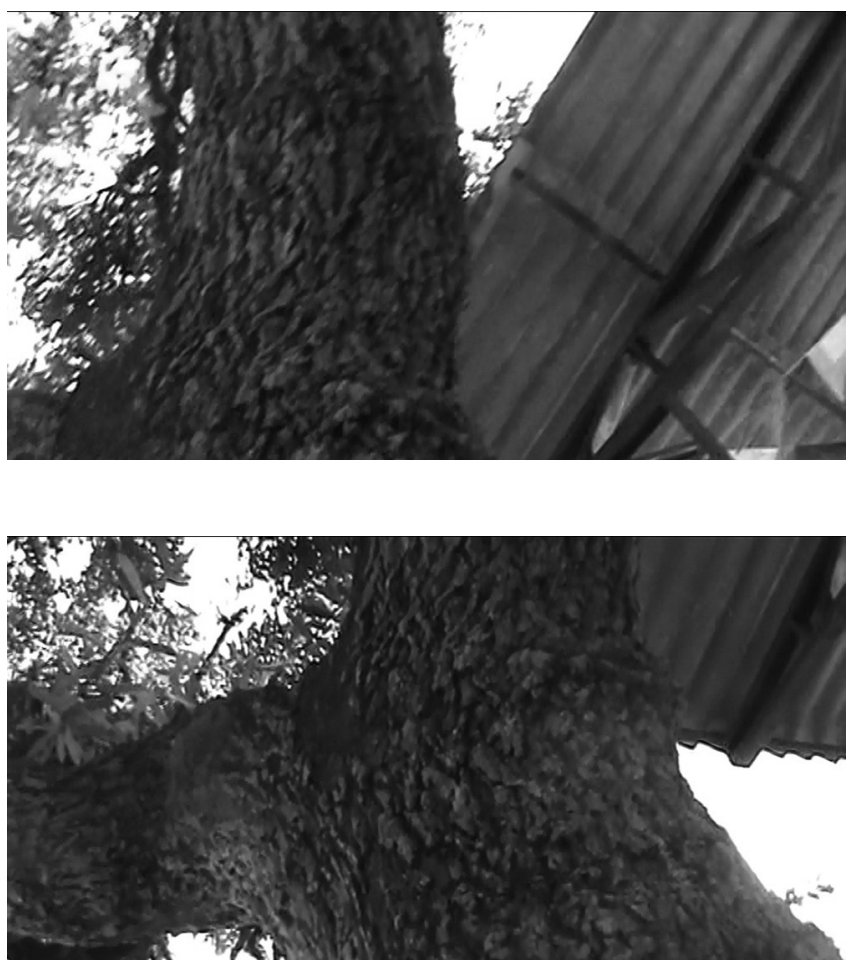

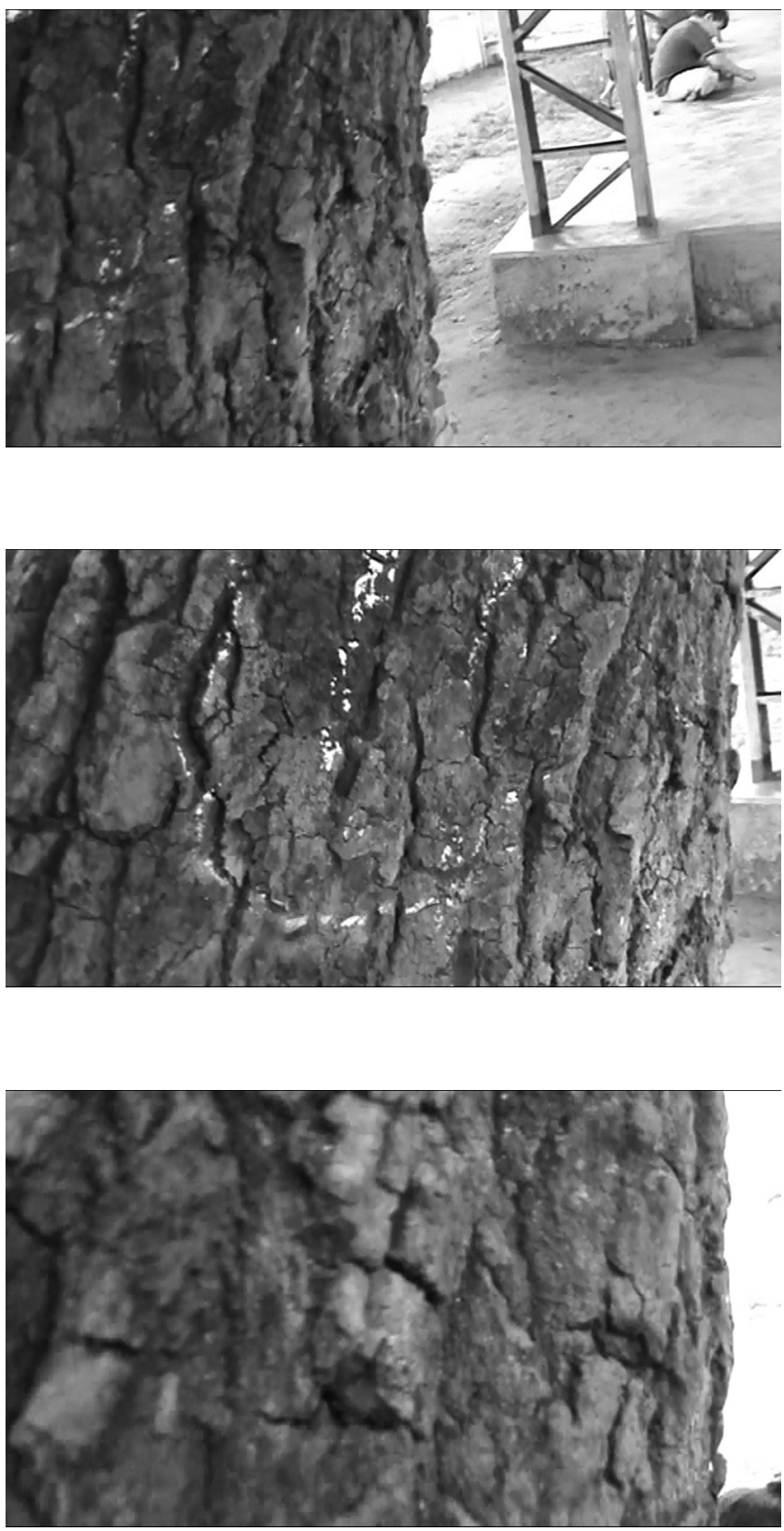

Fonte: $<$ https://www.youtube.com/watch?v=dGSk5up45Xs $>$ 


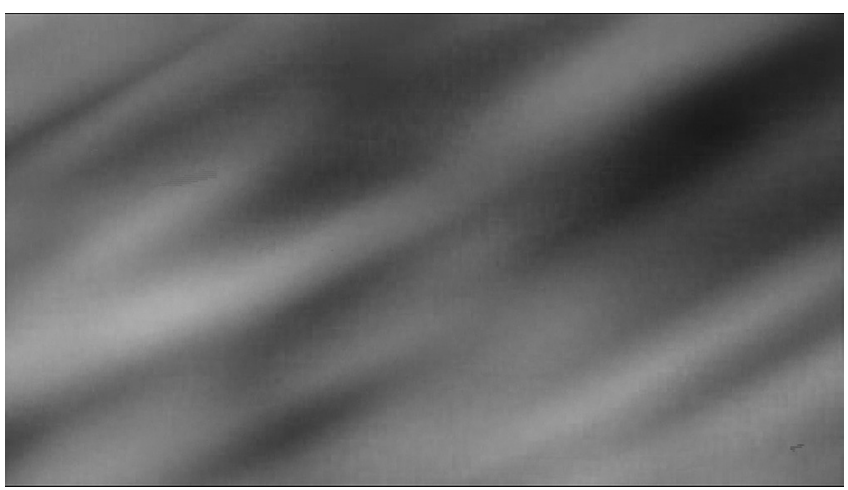

(Pré I, 2012, 5 6)

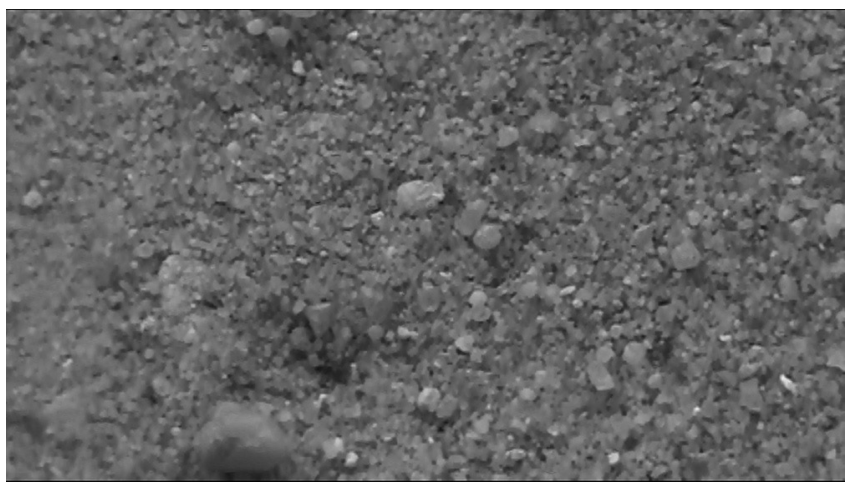

(Pré I, 2012, 6º 8)

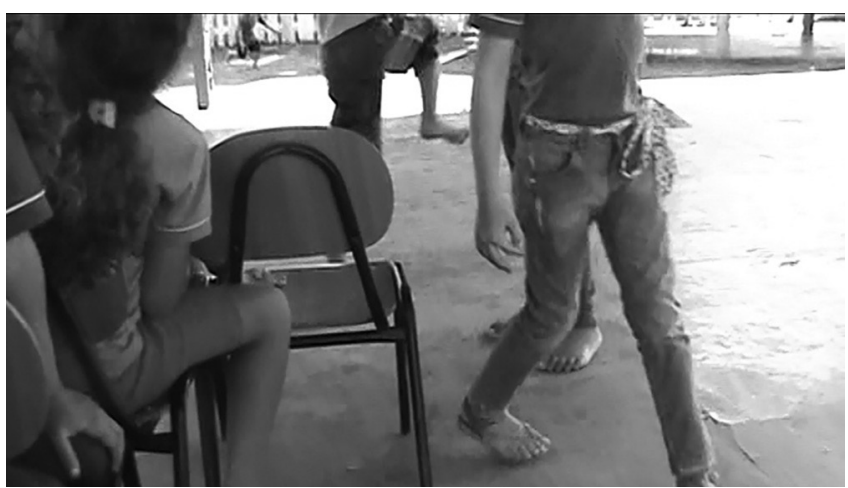

(Pré II, 2012, 129 9) 


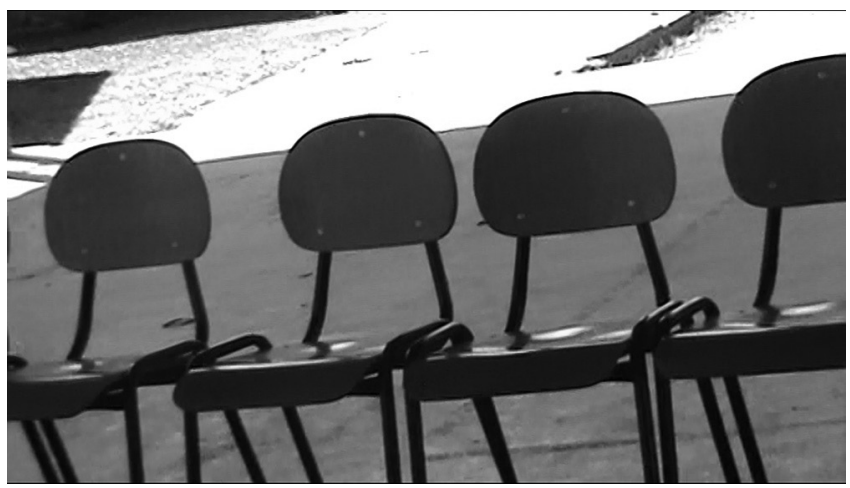

(Pré II, 2012, 129)
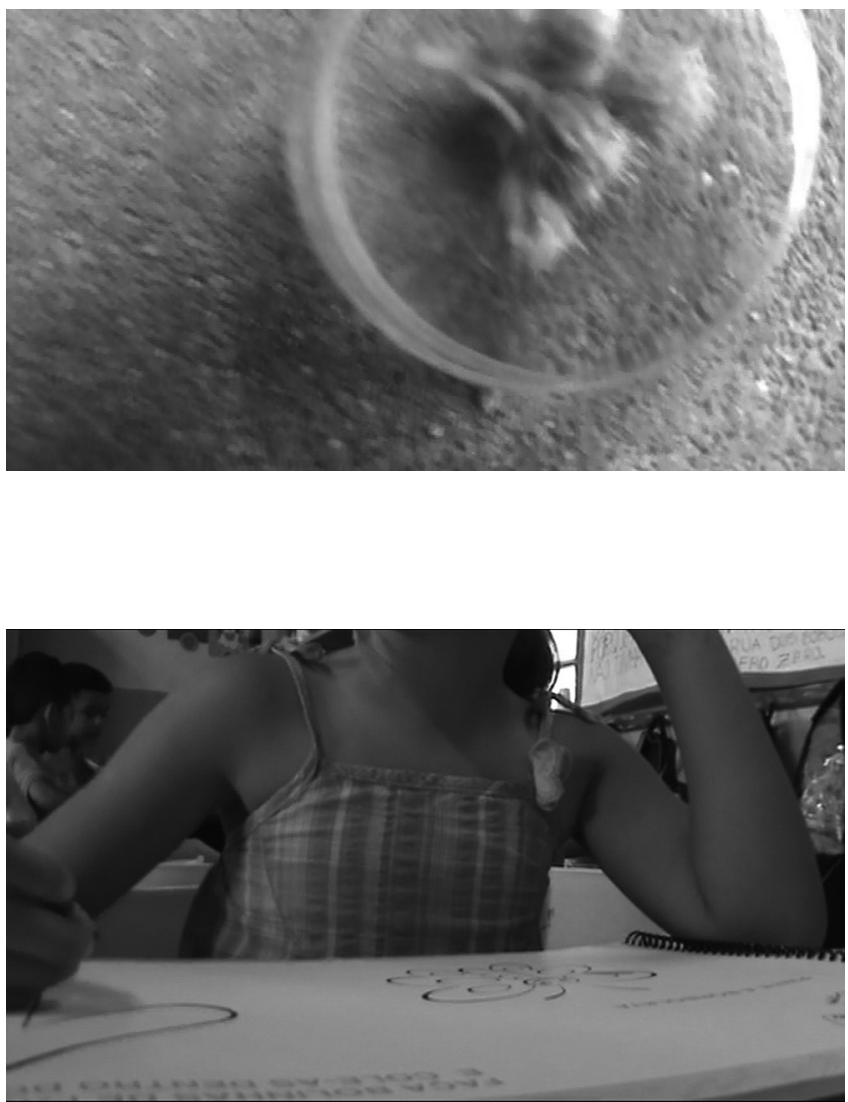


\section{BIANCA SANTOS CHISTÉ}

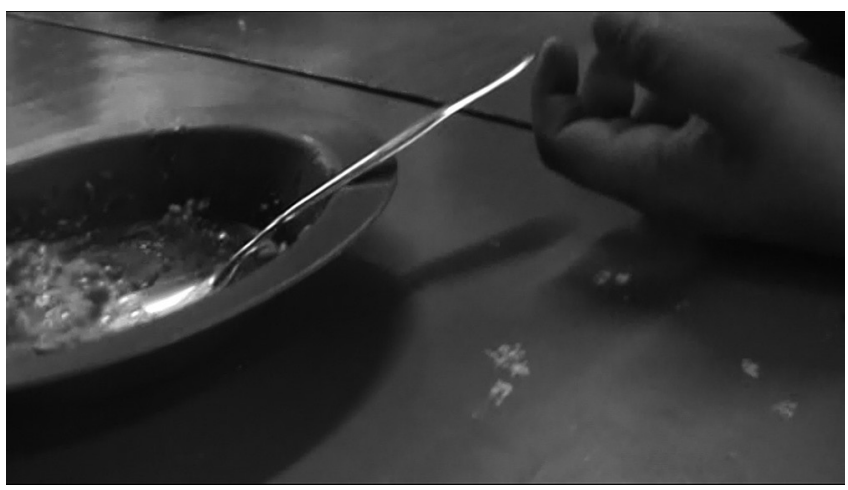




\section{ENCONTROS COM...}

ABRAMOWICZ, A.; Levcovitz, D.; Rodrigues, T. C. Infâncias em Educação Infantil. Pro-Posições, Campinas, v.20, n.3 (60), p.179-97, set.-dez. 2009.

ARIÉS, P. História social da criança e da família. Trad. Dora Flaksman. 2.ed. Rio de Janeiro: LTC, 1981.

Agamben, G. Infância e história: destruição da experiência e origem da história. Belo Horizonte: Editora UFMG, 2005. Profanações. São Paulo: Boitempo Editorial, 2007.

ARENDT, H. A condição humana. Rio de Janeiro: Forense Universitária, 2009.

Bachelard, G. Bachelard. Seleção de texto de José Américo Motta Pessanha. São Paulo: Abril Cultural, 1978. (Col. Os Pensadores)

. A poética do devaneio. São Paulo: Martins Fontes, 1988. . A terra e os devaneios do repouso: ensaio sobre as ima-

gens da intimidade. São Paulo: Martins Fontes, 1990. A terra e os devaneios da vontade. São Paulo: Martins Fontes, 1991.

A água e os sonhos. São Paulo: Martins Fontes, 1998,

BARROS, M. Memórias inventadas: as infâncias de Manoel de Barros. São Paulo: Editora Planeta do Brasil, 2010. Poesia completa. São Paulo: Leya, 2013. 
BENJAMIN, W. Rua de mão única - Obras escolhidas II. São Paulo: Brasiliense, 1987.

. Magia e técnica, arte e política-Obras escolhidas I. São Paulo: Brasiliense, 1994.

Reflexões sobre a criança, o brinquedo e a educação. São Paulo: Duas Cidades, 2002.

BRASIL, A. Modulação/Montagem: ensaio sobre biopolítica experiência estética. Rio de Janeiro, 2008. Tese (Doutorado em Comunicação) - Faculdade de Comunicação da Universidade Federal do Rio de Janeiro.

CALVINO, I. Palomar. São Paulo: Companhia das Letras, 1994.

CARROLL, L. Alice - Aventuras de Alice no País das Maravilhas e Através do espelho. Edição Comentada. Rio de Janeiro: Jorge Zahar, 2002.

CLARETO, S. Na travessia: construção de um campo problemático. In: CLARETO, S.; ROTONDO, M. A. S.; VEIGA, A. L. V. S. da. Entre composições: formação, corpo e educação. Juiz de Fora: Editora da UFJF, 2011.

COLLODI, C. As aventuras de Pinóquio. São Paulo: Companhia das Letrinhas, 2002.

CORAZZA, S. M.; TADEU, T. Composições. Belo Horizonte: Autêntica, 2003.

COUTO, M. Um rio chamado tempo, uma casa chamada terra. São Paulo: Companhia das Letras, 2003.

DELEUZE, G. Proust e os signos. Rio de Janeiro: Forense, 1987. Diferença e repetição. Rio de Janeiro: Graal, 1988.

. Crítica e clínica. São Paulo: Editora 34, 1997.

. Lógica do sentido. São Paulo: Perspectiva, 2011.

DELEUZE, G.; GUATTARI, F. O que é filosofia. Rio de Janeiro: Editora 34, 1992.

Mil Platôs: capitalismo e esquizofrenia. Vol. 1. Rio de Janeiro: Editora 34, 1995.

Mil Platôs: capitalismo e esquizofrenia. Vol. 3. Rio de Janeiro: Editora 34, 1996.

Mil Platôs: capitalismo e esquizofrenia. Vol. 4. São Paulo: Editora 34, 1997.

Kafka: para uma literatura menor. Lisboa: Assírio \& Alvin, 2003. 
O anti-Édipo: capitalismo e esquizofrenia. Rio de Janeiro: Editora 34, 2010.

DELEUZE, G.; PARNET, C. Diálogos. Trad. Eloísa Araújo Ribeiro. São Paulo: Escuta, 1998.

FERNANDES, H. R. Infância e modernidade: doença do olhar. In: Ghiraldelli Jr., P. (Org.). Infância, escola e modernidade. São Paulo: Cortez, 1997.

CARVALHO, A. F. de. Governo da infância e ontologia política do devir deficiente: implicações para a educação. 2014. Disponível em: <http://www.filoeduc.org/viicife/anais. asp\#>. Acesso em: set. 2014.

FOUCAULT, M. Microfísica do poder. Rio de Janeiro: Graal, 1985.

GAGNEBIN, J.-M. Sete aulas sobre linguagem, memória e história. Rio de Janeiro: Imago, 2005.

História e narração em Walter Benjamin. São Paulo: Perspectiva, 2011.

GALLO, S. Infância e poder: algumas interrogações à escola. In: KOHAN, W. (Org.). Devir-criança da filosofia. Belo Horizonte: Autêntica, 2009.

Ghiraldelli Jr., P. (Org.). Infância, escola e modernidade. São Paulo: Cortez, 1997.

HOLLANDA, C. B. de. Tantas palavras. São Paulo: Companhia das Letras, 2006.

KASTRUP, V. A invenção de si e do mundo: uma introdução do tempo e do coletivo no estudo da cognição. Campinas: Papirus, 1999.

. Devir-criança e a cognição contemporânea. Psicologia: Reflexão e Crítica, n.13, v.3, p.373-82, 2000.

KOHAN, W. Infância, entre a educação e a filosofia. Belo Horizonte: Autêntica, 2005.

Infância, estrangeiridade e ignorância. Belo Horizonte: Autêntica, 2007.

LARROSA, J. Notas sobre a experiência e o saber experiência. Revista Brasileira de Educação, n.19, jan.-abr. 2002.

As crianças e as fronteiras: varias notas a propósito de três filmes de Angelopoulos e uma coda sobre três filmes iranianos. In: TEIXEIRA, I. A. de C.; LARROSA, L. e LOPES, J. de S. (Orgs.). A infância vai ao cinema. Belo Horizonte: Autêntica, 2006. 
. Niños atravesando el paisaje. Notas sobre cine e infancia. In: DUSSEL, I.; GUTIERREZ, D. Educar la mirada: políticas y pedagogías de la imagen. Buenos Aires: Manantial, OSDE, 2006a.

Pedagogia profana: danças, piruetas e mascaradas. 5.ed. Belo Horizonte: Autêntica, 2010.

Tremores: escritos sobre experiência. Belo Horizonte: Autêntica, 2014.

LEITE, C. D. P. Infância, experiência e tempo. São Paulo: Cultura Acadêmica, 2011.

Cinema, educação e infância: fronteiras entre educação e emancipação. Fermentário, v.2, n.7, 2013.

; LEITE, A. R. I. P. Imagens como epígrafe: imagens lúdicas de experiência infantil. 2014. Disponível em: $<$ http://www.filoeduc.org/viicife/adm/impressos/trabalhos/TR130.pdf > . Acesso em: set. 2014.

LISPECTOR, C. Felicidade clandestina. São Paulo: Ática, 1998.

MASSCHELEIN, J. Educando o olhar: a necessidade de uma pedagogia pobre. Educação e Realidade, v.33, n.1, jan.-jun. 2008.

NARODOWSKI, M. Infância e poder: a conformação da pedagogia moderna. Bragança Paulista: Editora da Universidade São Francisco, 2001.

NIETZSCHE, F. Assim falou Zaratustra. São Paulo: Companhia das Letras, 2011.

Rancière, J. A partilha do sensível: estética e política. São Paulo: Editora 34, 2009.

. O espectador emancipado. São Paulo: Martins Fontes, 2012.

SCHÉRER, R. Infantis: Charles Fourier e a infância para além das crianças. Belo Horizonte, Autêntica, 2009.

ZEPPINI, P. S. Deleuze e o corpo: articulações conceituais entre Deleuze, Nietzsche e Espinosa em função da problemática do corpo. Campinas, 2010. Dissertação (Mestrado em Filosofia) -Instituto de Filosofia e Ciências Humanas da Universidade Estadual de Campinas. 


\section{UM PÓS-ESCRITO DE UM ENSAIO EM COMPOSIÇÃO}

Quanto de uma criança, da infância pode entrar em um olho? Um olho, um olhar abarcaria uma criança? A infância? E se criança e infância não coubessem em olho algum, mas se compusessem olhando conosco o mundo numa intimidade febril e desconcertante?

Nada más arrogante que querer ponerse en el lugar de un niño. Nada más arrogante que tratar de comprenderlo desde su interior. Nada más arrogante que intentar decir, con nuestras palabras de adulto, lo que es un niño. (Larrosa, 2006a, p.120)

Como traduzir em palavras o que parece não ser feito de palavras? Falar e escrever, mesmo que seja uma tentativa de escrever com criança, com infância é muito difícil. Assumo aqui, então, que o meu olhar está viciado, carregado de imagens de infância e de criança. Então suspeito de mim mesma. Olhei, e ainda olho, às produções imagéticas das crianças suspeitando de mim em tudo o que vejo e digo. Queria falar, escrever, pensar distanciando-se das ideias psicologizadas e pedagogizadas que pairam sobre a infância e a criança; afastar-se da insistente fixação 
da infância e da criança em um ponto quieto, prostrado, cheio em representações, incapaz aos encontros, pautada em contar leis e regras existentes no mundo. Queria falar, talvez, da criança nesse estado tartamático dela, falar de uma matemática gaguejante, de uma educação também gaguejante. Talvez não o gaguejar da criança, mas do meu próprio gaguejar. Também do meu gaguejar. Da tartamuda experiência de ascender à criança. Porque para ir ao encontro da criança, da infância precisei (e ainda preciso) abandonar os vícios, abandonar meu mundo, o mundo criado que me afasta da criança, isso parece utópico, paradoxal.

Como que posso suspender minha linguagem, minha experiência, o meu tudo para olhar o mundo, os seres, as coisas, as crianças, a infância? Talvez eu não possa. Mas posso suspeitar de mim, posso suspeitar que não sei tudo, posso suspeitar que já esqueci como que era ser criança e eu já nem sei se a criança que está na minha frente esta sendo a criança que um dia eu fui. As experiências são tão diferentes, porém, quem sabe, é inegável, ninguém pode contrapor que a experiência ali está no estado virgem, ela é a primeira vez, é inaugural, ela é alegria de descobrir o formigueiro, ela é a alegria de descobrir que não é terra, não é areia, é um monte de pedrinhas.

Pedrinhas? Que olhar é esse que se abre a partir do encontro com a infância, com a criança? O que vemos para além das formas e dos sujeitos, do dado, do acabado e do determinado na coexistência da criança conosco? Conosco, nos atravessando, sendo atravessados por devires. Um encontro entre - "sem temporalidade cronológica, mas com geografia, com intensidade e direção própria” (Kohan, 2007, p.95). Devir-criança. E se um devir-criança duvidasse, perguntasse, nos perguntasse, perguntasse a matemática, se não há outra matemática e outra educação possível? 
Possível seria se a educação, a educação na infância não percorresse em linha reta, mas em ziguezagues, mediante oscilações, desmentidas, em meio às quais as certezas, as verdades de suas afirmações fossem fugazes? E se funcionasse como pintura modernista, não permitindo nenhuma totalização, nem reintegração, nem regeneração? Mas a composição de elementos díspares e divergentes, de partes heterogêneas, onde, como as mulheres de Picasso, (Corazza; Tadeu, 2003, p.53) "não há nenhum ângulo privilegiado, nenhum ponto de vista focal". Talvez as crianças, a infância diriam como Barros (2013, p.159):

Há quem receite a educação ${ }^{1}$, a educação na infância ao ponto de osso, de oco, ao ponto de ninguém e de nuvem.

Sou mais a educação com febre, decaída, fodida, na sarjeta. Sou mais a educação ao ponto de entulho.

Amo arrastá-la no caco de vidro, enxergá-la pro chão, corrompê-la

Até que padeça de mim e me suje de branco.

Sonho exercer com ela o ofício de criada:

Usá-la como quem usa brincos.

Poderíamos pensar na educação a possibilidade de devir-criança? De uma experimentação das potências no infantil? $\mathrm{Na}$ abertura de fendas, de fissuras dos saberes institucionalizados? Compor sempre o inusitado a partir do encontro com outros corpos, navegando incessantemente em novas maneiras de profanar os lugares, os territórios, os tempos, os espaços? Em uma educação onde os corpos compusessem novas maneiras de ser, como nos apresenta Deleuze e Guattari (1996, p.11)? "Por que não caminhar com a cabeça, cantar com o sinus, ver com a pele, respirar com o ventre"?

1 Poesia adaptada. 
Respirar com o ventre seria possível em uma educação, em uma educação na infância que se permitisse afetar e ser afetado, em que as multiplicidades de experiências acontecessem, em que as sensações, os corpos não fossem aprisionados e até mesmo subtraídos? Uma educação com o corpo, pelo corpo, no corpo, corpos com multiplicidades de possibilidades, de intensidades, de velocidades. Corpos sendo atormentados no desassossego do pensar. Corpos rebeldes à procura de experiências, zerados das regras impostas, transcendentes e transcendo os limites impostos ao corpo e ao pensamento. Corpos em plena experiência funcionando "sem apertar o botão". (Barros, 2013, p.145),

Botão que não se aperta para as crianças se lançarem na aventura de sentir, perceber, afetar, se sensibilizar, de pensar. Por onde caminham os pensamentos das crianças? Talvez, quem sabe, os pensamentos das crianças caminham como passeantes nômades, em expedições, em geografias como nos diz Deleuze e Parnet (1998, p.26), "sem causa, sem razão, sem respeito, sem pretexto...", como fronteiras movediças. Movediço, abalador, distanciado dos modelos, das modulações, distante ainda, da ditadura do corpo, do sentido, do tempo.

Tempos outros, de uma criança tomada por si mesma que pode mobilizar as potências de um devir-criança? Uma potência que permite pensar o convívio com as incertezas, sem se prender a modelos e as estratificações? Como seria pensar uma educação para criança a partir da criança? Uma educação em movimento, em outro tempo, em outros espaços, de saberes não fixados, nem organizados? As crianças se lançam em descobrir, experienciar o mundo antes mesmo de nomeá-lo. Antes mesmo de alguém nomeá-lo a elas e por elas. As verdades produzidas pelas crianças consistem num contínuo e incessante desdobramento da diferença. Uma coisa e outra e mais 
outra. Um olhar que se abre para um outro, que se abre sucessivamente para muitos outros.

Outro? Outra educação, educação na infância? Sem conteúdo, sem forma, sem ordem, sem limites, sem aprisionamentos, uma fora da lei? Talvez há na infância, na criança uma busca baseada em decisões não premeditadas, não pré-estabelecidas, em encontros não antecipados, provocados, suscitados e organizados. Lançam-se a experienciar, experimentar o mundo produzindo regras, normas que duram infinitivamente quanto duras um instante. Para Bachelard (1988, p.182), “o mundo é constituído pelo conjunto de nossas admirações. Admira primeiro, depois compreenderás”. Já Deleuze (1987, p.95) nos diz, "A inteligência vem sempre depois; ela é boa quando vem depois, só é boa quando vem depois".

Depois viria o que? A explicação, a regra permanente, inflexível, a verdade absoluta? Absoluta verdade de quem? Quem a tem? Outras verdades poderiam ser pensadas, inventadas em uma educação dançarina. E se uma educação dançarina fosse mais que uma metá-fora e em vez de meter-fora do universo educativo, metesse bem dentro desse universo e produzisse uma fissura, uma abertura, uma cisão, um rasgão nos modos de produzir uma educação, uma educação na infância? E se a educação, a educação na infância não normatizasse, não padronizasse, não disciplinasse, não tutelasse? Uma educação estranha a toda forma solidificada, solidificante, mas adepta a formas que formam e se deformam.

Deformar uma educação em forma tendo como princípio efetivo o exercício repetitivo de ser criança, onde o mundo, os seres, as coisas não tenham função explicativa, mas brincativa: "fazer peraltagens com as palavras" (Barros, M., 2013), encher a matemática de incompletude, “escrever absurdez para abortar o bom senso" (ibidem), compor-se de atos, ruídos, cheiros, sabores, escutar a cor 
do vento, fazer pegar delírio no verbo, pentear e desarrumar os pensamentos como as garças, "desregular a natureza" (ibidem), "ter predominância vegetais do que platônicas” (ibidem), olhar com olhar de árvore, contrair visão fontana, dar às pedras costume de flor, inaugurar o formato das coisas etc.

Inaugurar os formatos desformandos-os incessantemente poderia acontecer em uma educação vagamundo (Corazza; Tadeu, 2003), em uma educação dançarina? Uma educação transeunte, deslizante, de movimentos rápidos, leves, uma educação que se experimenta e se deixa experimentar, que esta sempre criando, inventando e se modificando. Uma educação que invoca aumentar a potência de agir, fazer a vida vibrar e se inventar, acionar a diferença, a invenção, movimentar encontros e composições, atravessar os corpos de crianças e adultos como raios, numa velocidade de desterritorialização dos regimes de propriedade, da legitimidade e da delimitação enraizada sobre os eixos norteadores, sobre as temáticas e disciplinas educativas e faz, como sugere Kohan (2007, p.98): “[... desdobrar potências impensadas na infância”.

Quiçá consigamos deixar de nos preocupar tanto em transformar as crianças em algo diferente do que elas são, para pensar se acaso não seria interessante uma escola que possibilitasse a crianças e adultos, professoras, professores, gestores, orientadores, diretores, enfim, a quem seja, encontro esses devires minoritários que não aspiram a imitar nada, a modelar nada, mas a interromper o que está dado e propiciar novos inícios. (Kohan, 2007, p.97)

[...] possamos encontrar um novo início para outra ontologia e outra política da infância naquela que não busca normatizar o tipo ideal ao qual uma criança deva se conformar, ou o tipo de sociedade que uma criança tem que construir, mas 
que busca promover, desencadear, estimular nas crianças e em nós mesmos essas intensidades criadoras, disruptoras, revolucionárias que podem surgir da abertura do espaço, no encontro entre o novo e o velho, entre uma criança e um adulto. (Kohan, 2007, p.97-8)

Ah, se já perdemos a noção da hora Se juntos já jogamos tudo fora Me conta agora como hei de partir

Se, ao te conhecer, dei pra sonhar, fiz tantos desvarios Rompi com o mundo, queimei meus navios Me diz pra onde é que inda posso ir

Se nós, nas travessuras das noites eternas Já confundimos tanto as nossas pernas Diz com que pernas eu devo seguir Se entornaste a nossa sorte pelo chão Se na bagunça do teu coração

Meu sangue errou de veia e se perdeu

Como, se na desordem do armário embutido Meu paletó enlaça o teu vestido E o meu sapato inda pisa no teu

Como, se nos amamos feito dois pagãos Teus seios inda estão nas minhas mãos Me explica com que cara eu vou sair

Não, acho que estás se fazendo de tonta Te dei meus olhos pra tomares conta Agora conta como hei de partir

(Chico Buarque de Holanda, 2006, p.299) 
152 BIANCA SANTOS CHISTÉ
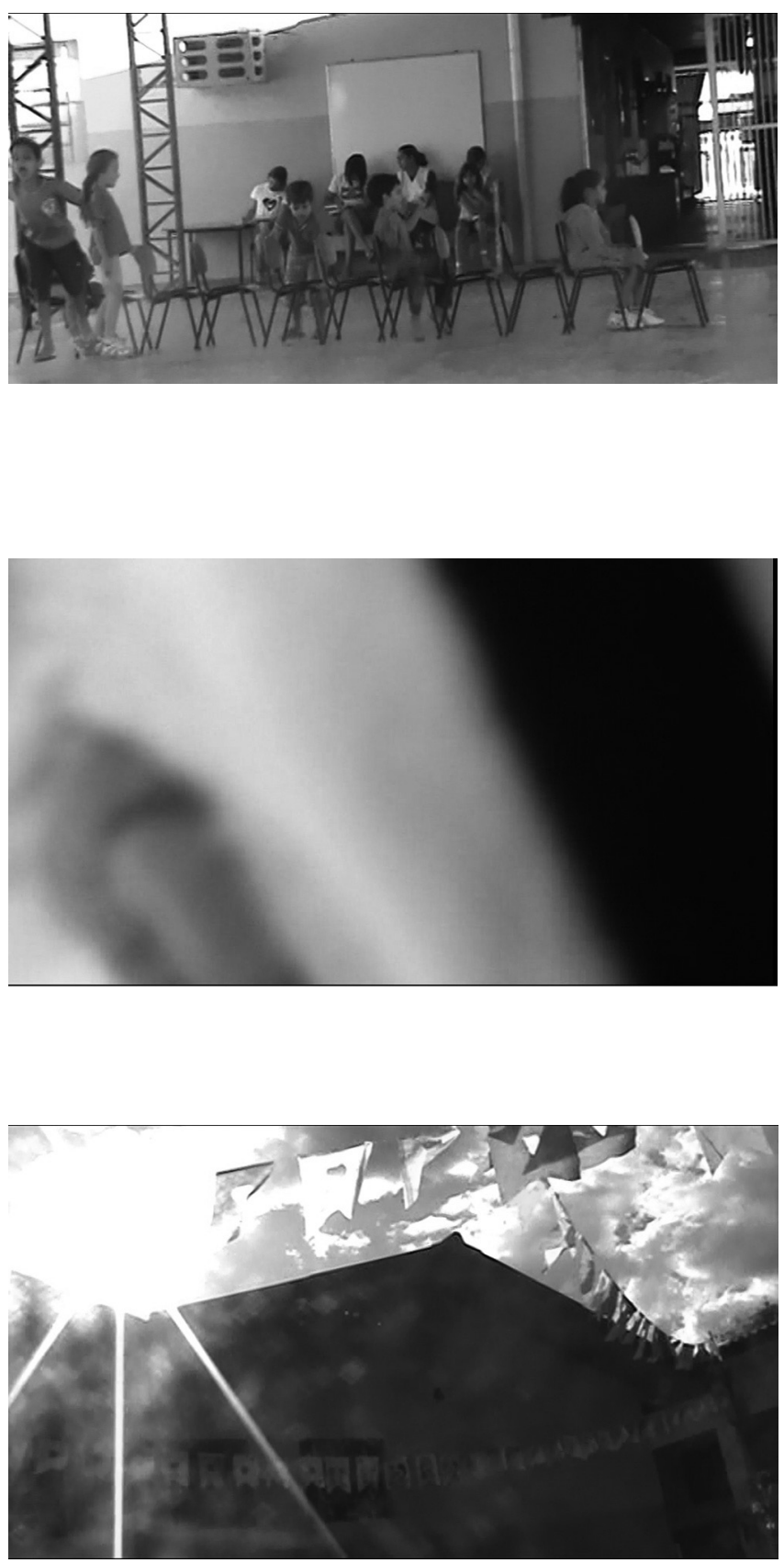
INFÂNCIA, IMAGENS E VERTIGENS 153

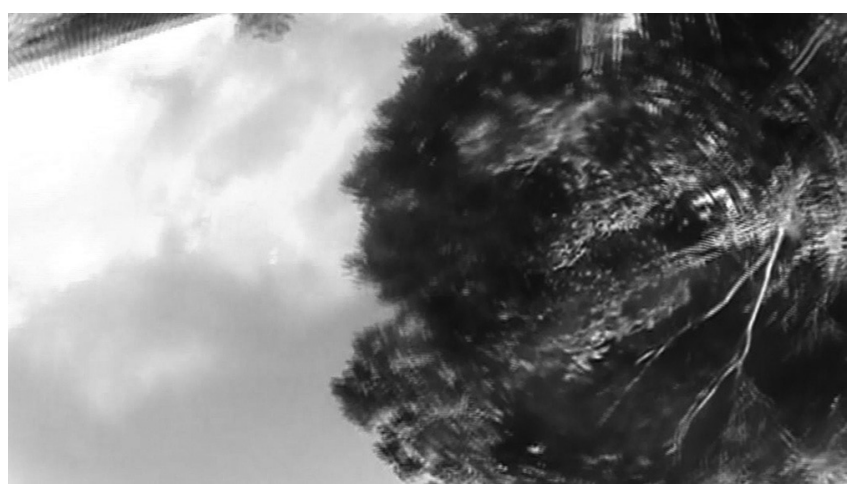




\section{SOBRE O LIVRO}

Formato: $12 \times 21 \mathrm{~cm}$

Mancha: 20,4 x 42,5 paicas

Tipologia: Horley Old Style 10,5/14

Papel: Offset $75 \mathrm{~g} / \mathrm{m}^{2}$ (miolo)

Cartão Supremo $250 \mathrm{~g} / \mathrm{m}^{2}$ (capa)

1a edição: 2015

EQUIPE DE REALIZAÇÃO

Coordenação Geral

Marcos Keith Takahashi 


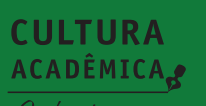

